\title{
Climate Change and Oregon Law: What Is to
}

\section{Be Done? ${ }^{1}$}

Introduction

A. Limitations and Obligations ........................................ 240

B. What Must Be Done................................................. 241

I. Oregon Property Law and Climate Change.......................... 244

A. Property Law Foundations ............................................ 244

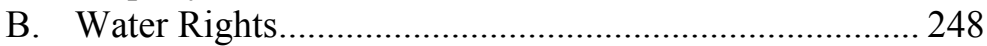

C. Boundary Law Issues .................................................. 250

D. Water and Its Use and Enjoyment................................256

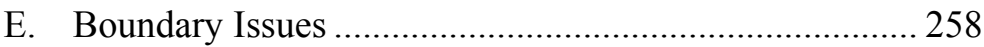

F. Fundamental Decision.................................................... 260

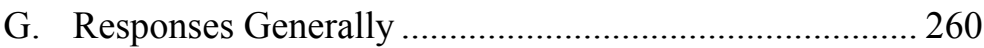

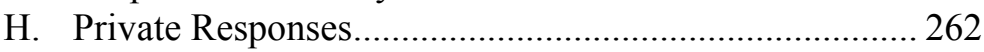

I. Strategies and Technologies........................................ 265

J. Property Rights Summary .......................................... 266

* J.D. Lewis and Clark College, Northwestern School of Law, 1970; M.B.A., University of Oregon, 1992; Retired Counsel, First American Title Co.

${ }^{\dagger}$ B.A., U. of Oregon (Political Science) 1961; M.A. U. of Denver (Economics) 1965; J.D. U. of Oregon 1968, Member and Vice Chair of the initial Oregon Land Conservation and Development Commission (1973-1976); Member Oregon Energy Facilities Siting Council 1990-1998); Organizer and Board Chair, Energy Trust of Oregon (2001-2005).

${ }^{\ddagger}$ B.A., St. John’s University (N.Y.), 1966; J.D., Willamette University, 1969; M.A. (History), Portland State University, 1973; Urban Studies Certificate, Portland State University, 1974; M.A. (Political Thought), University of Durham; Diploma in Law, University College, Oxford, 1984; LL.M., University College, London, 1978. Adjunct Professor of Urban Studies and Planning, Portland State University.

1 Thanks to retired DLCD staff member Jim Knight, Willamette University Professor Russ Beaton, and Attorney-Lecturer John Gould for their reviews and helpful comment on earlier drafts of parts of this Article. The opinions expressed herein are the responsibility of the coauthors. 
II. Recommended Changes to Statewide Planning Goals and

Related Rules and Policies Necessitated by Climate

Change.

A. Mitigation Potential for Land Use Goals and Climate

Change: Transportation (Goal 12), Energy

Conservation (Goal 13), and the Urban Growth

Boundary (Goal 14).

1. Mitigation Potential 1-Amend Goals to Reflect

Ecodistricts and Climate Start Strategies

2. Mitigation Potential 2-Revise Goal 13

3. Mitigation Potential 3-Amend Goal 12

4. Mitigation Potential 4-Amend Goal 14

B. Adaptation Potential for Land Use Goals and Climate Change: Air, Water, and Land Use (Goal 6); Hazards (Goal 7), the Willamette River (Goal 15); Estuaries (Goal 16); Coastal Shorelands (Goal 17); Beaches and Dunes (Goal 18); and Ocean Resources (Goal 19).. 282

1. Adaptation Potential 1-Amend Goal 6 .................... 282

2. Adaptation Potential 2-Amend Goal 7 .................... 284

3. Adaptation Potential 3-Modify Goal 16 ................. 293

4. Adaptation Potential 4-Modify Goal 17 ................. 295

5. Adaptation Potential 5-Amend Goal 18 .................. 300

6. Adaptation Potential 6-Amend Goal 19 .................. 302

7. Adaptation Potential 7-Modify the Greenway Goal 306

C. Sequestration Potential for Land Use Goals and Climate Change: Forests (Goal 4), Agriculture (Goal 3), and Open Space (Goal 5) .......................................... 306

1. Sequestration Potential 1-Modify Goal 4 ............... 307

2. Sequestration Potential 2-Modify Goal 3 ................ 311

3. Sequestration Potential 3-Modify Goal 5 ................ 313

D. Land Use Process and Practice Issues-Goals and Climate Change: Citizen Involvement (Goal 1); Land Use Planning (Goal 2), and Related Processes.

1. Procedure Change 1-Adopt a Legislative Mandate to update Goals for Climate Change. 316

2. Procedure Change 2-Establish Land Use Path to 2050 Targets

3. Procedure Change 3-Require Wholesale Review of Oregon Statutes to Deal with Climate Change..... 317 
4. Procedure Change 4-Provide an Express

Statement of Public Trust in Discretionary

Permitting Procedures

5. Procedure Change 5-Reinstate Periodic Review ..... 319

6. Procedure Change 6-Modify Tort Liability for Elected Officials Who Ignore Climate Change

E. Is Oregon Doing Enough, Soon Enough to Meet Its

Share of the Climate Change?

Conclusion

Appendix

\section{INTRODUCTION}

In this second decade of the twenty-first century, climate change is an irrefutable fact. ${ }^{2}$ The world is becoming hotter ${ }^{3}$ and, in many areas, drier. ${ }^{4}$ Sea level rise as a result of melting glaciers threatens to inundate islands and change existing shorelines. ${ }^{5}$ Moreover, the hypoxia found in "dead zones" off the Oregon Coast threatens the

2 See NAT'L ACAD. OF SCI., Climate Change: Evidence and Causes, NAT'L ACAD. OF SCIS. (Feb. 27, 2014), http://dels.nas.edu/resources/static-assets/exec-office-other/climate -change-full.pdf (explaining that notwithstanding the skeptics, the National Academies of Science strongly supports the evidence that climate change is real and profound in its effects); see also Climate change: How do we know?, [NASA GLOBAL CliMATE CHANGE Vital Signs of the Planet,] NAT'L Aeronautics \& SpaCe Admin., http://climate.nasa.gov/evidence/ (last visited Apr. 8, 2018).

3 See, e.g., GISS Surface Temperature Analysis (GISTEMP), NAT'L AERONAUTICS \& SPACE ADMIN., GODDARD INST. FOR SPACE STUDIES, http://data.giss.nasa.gov/gistemp/ (last visited Apr. 8, 2018) (providing an "estimate of global surface temperature change"); Climate Change Indicators in the United States, U.S. ENVTL. PROT. AGENCY 18 (2016), https://www.epa.gov/sites/production/files/2016-08/documents/climate_indicators_2016 .pdf (describing warmer temperatures as "one of the most direct signs that the climate is changing").

4 Extreme Dry, UNION OF CONCERNED SCIENTISTS, http://www.climatehotmap.org/glo bal-warming-effects/drought.html (last visited Apr. 8, 2018); Water and Climate Change, UNION OF CONCERNED SCIENTISTS, http://www.ucsusa.org/global_warming/science_and impacts/impacts/water-and-climate-change.html\#.Wc9VOBOCx0s ${ }^{-}$(last visited Apr. 8, 2018).

5 See Sea Level, [NASA Global Climate Change Vital Signs of the Planet,] NAT'L AERONAUTICS \& SPACE ADMIN., http://climate.nasa.gov/vital-signs/sea-level/ (last visited Apr. 8, 2018) (showing a rate of change in sea level of $3.2 \mathrm{~mm}$ per year, due to glacial melting and the "expansion of sea water as it warms"); How is sea level rise related to climate change?, NAT'L OCEAN SERV., NAT'L OCEANIC \& ATMOSPHERIC ADMIN., [U.S. DEP'T OF COMMERCE], http://oceanservice.noaa.gov/facts/sealevelclimate.html (last updated Oct. 10, 2017) (describing how sea level rise can increase global temperatures and add more water to the ocean). 
vitality of the state's fishing industry. ${ }^{6}$ For Oregon, which has a temperate weather pattern with sufficient rain in the western part of the state and a relatively small population for the size of its land area, the prospect of climate change may have diffuse impacts. These impacts may manifest in such forms as Congressional decisions regarding national allocation of water and the necessity of dealing with "climate refugees" from states that are less environmentally well-off. The question is whether the state is prepared to do so. It is difficult to overstate the immediate threat posed by climate change to Oregon, ${ }^{7}$ the United States, ${ }^{8}$ and the world. James Hansen ${ }^{9}$ suggests

\footnotetext{
${ }^{6}$ Dead Zones of the Pacific Northwest, NAT'L OCEANIC \& ATMOSPHERIC AdMIN., https://oceantoday.noaa.gov/deadzonespacnw/ (last visited Apr. 8, 2018); New Ways of Taking the Pulse of Oregon's “Dead Zones”, NAT'L SCI. FOUND., https://www.nsf.gov /news/special_reports/deadzones/glider.jsp (last visited Apr. 8, 2018).

${ }^{7}$ Juliana v. United States, 217 F. Supp. 3d 1224 (2016). Young environmental activists in Oregon have filed a case against the United States, alleging that continuing to ignore the realities of climate change will damage them, future generations, and the environment. Id. at 1233. The case has gained national attention. Ciara O'Rourke, The 11-Year-Old Suing Trump Over Climate Change, THE ATlantiC (Feb. 9, 2017), https://www.theatlantic .com/science/archive/2017/02/trump-climate-lawsuit/516054/. Thus far, Defendants' Motions to Dismiss have been denied and the case is proceeding to trial. Juliana $v$. U.S.-Climate Lawsuit, OUR CHILDREN'S TRUST, https://www.ourchildrenstrust.org/us /federal-lawsuit/ (last visited Apr. 8, 2018) (After the District Court's decision in Juliana, the United States petitioned for a writ of mandamus ordering the District Court to dismiss the case on the grounds that it would be burdensome and threaten the separation of powers. On March 7, 2018, in United Sates of America v. United States District Court for the District of Oregon (D.C. No. 6:15-cv-01517), a panel of the 9th Circuit Court of Appeals denied the petition without prejudice, thus causing the parties to proceed to discovery and trial.).

${ }^{8}$ See U.S. Global Change Research Program (USGCRP), Executive Summary, in 1 Climate Science Special Report: Fourth National Climate Assessment 12-34 (Wuebbles, D.J. et al. eds., 2017). True to his campaign promises, President Trump has ordered reviews of administrative rules to limit federal environmental regulation of the "Waters of the United States" (WOTUS) and the Clean Power Plan rules promulgated by the Obama administration. See Waters of the United States (WOTUS) Rulemaking, U.S. ENVTL. PROT. AGENCY, https://www.epa.gov/wotus-rule (last updated Nov. 21, 2017) (providing information about WOTUS rule and rulemaking); Rapanos v. United States, 547 U.S. 715 (2006) (showing the particular importance of the WOTUS actions, given the federal jurisdictional limits by the United States Supreme Court); Complying with President Trump's Executive Order on Energy Independence, U.S. ENVTL. PROT. AGENCY, https://www.epa.gov/Energy-Independence (last updated Oct. 26, 2016) (explaining the Executive Order that calls for a review of the Clean Power Plan).

${ }^{9}$ James Hansen is a respected climatologist and former head of the NASA Goddard Institute for Space Studies.
} 
that the world is on the brink of a "tipping point," after which, the harms wrought by climate change will be irreversible. ${ }^{10}$

This Article accepts the fact of climate change and attempts to set out some practical considerations and tools by which Oregon may respond to climate change. ${ }^{11} \mathrm{We}$ examine two aspects of that response. The first concerns planning and regulation of land, and the second concerns the effects of climate change on property law. We suggest that traditional property law doctrines, such as reliction, avulsion, property boundaries, and public easements should be reexamined in the light of this crisis.

Oregon's planning law is now over forty years old and is characterized by mandatory, binding planning by local governments, which provides the basis for land use regulation, state participation in local planning in the form of mandatory policies ("goals") which must be incorporated into local plans, and complex systems of procedural safeguards and review of decisions involving land use. ${ }^{12}$ Thus, an administrative structure is in place to respond to climate change, assuming policies and tools can be fashioned. In addition, local

${ }^{10}$ James Hansen, Tipping Point: Perspective of a Climatologist, in STATE OF THE Wild: A Global PoRTRAiT OF WildLIFE, WildLANDS, AND OCEANS 9 (Eva Fearn ed., 2008).

The crystallizing science points to an imminent planetary emergency. The dangerous level of carbon dioxide, at which we will set in motion unstoppable changes, is at most 450 parts per million (ppm), but it may be less. Carbon dioxide has already increased from a preindustrial level of $280 \mathrm{ppm}$ to $383 \mathrm{ppm}$ in 2007 , and it is now increasing by about 2 ppm per year. We must make significant changes within a decade to avoid setting in motion unstoppable climatic change.

Id. at 11-12. See also Katherine Bagley, For James Hansen, the Science Demands Activism on Climate, YALE ENV'T 360, (Apr. 12, 2016), http://e360.yale.edu/features /james_hansen_science_demands_action (detailing how Hansen continues to advocate for change in the climate change debate).

${ }^{11}$ With the exception of potential liability of public officials who fail to take action to deal with climate change, the issues of liability and apportionment of risk are left to legislative and judicial bodies, noting however that there is a case to be made for recovering damages for past pollution. See Mary Christina Wood \& Dan Galpern, Atmospheric Recovery Litigation: Making the Fossil Fuel Industry Pay to Restore a Viable Climate System, 45 ENVTL. L. 259 (2015) (proposing Atmospheric Recovery Litigation, a legal strategy which would "hold the major fossil fuel corporations liable for funding" the drawdown of atmospheric carbon dioxide). Wood's work further rethinks notions of liability and responsibility for pollution. See generally MARY CHRISTINA WOOD, NATURE'S TRUST: ENVIRONMENTAL LAW FOR A NEW ECOLOGICAL AGE (2014).

12 See generally Edward J. Sullivan, The Quiet Revolution Goes West: The Oregon Planning Program 1961-2011, 45 J. MARSHALl L. REV. 357 (2012) (describing the Oregon planning program). 
governments have weighed in on their own to deal with climate change issues. ${ }^{13}$ Nevertheless, there is still much to be done. ${ }^{14}$

\section{A. Limitations and Obligations}

Oregon property law is a mixture of British common law modified by statutes. However, the power to modify property law by statute may be limited by constitutional considerations. ${ }^{15}$ Nevertheless, the state may address climate change through the administration of its public trust responsibilities, ${ }^{16}$ as well as in its interpretation of common law property doctrines. ${ }^{17}$ While there is not presently a case on point, it is likely that improvements by property owners will

13 See, e.g., Climate Action Plan, City of Portland, OR. \& Multnomah County (2015) [hereinafter Climate Action Plan], https://www.portlandoregon.gov/bps/article/531 984 (describing how the plan deals with baseline emissions and provides practical policies ranging from consumption to carbon sequestration).

14 See generally, Biennial Report to the Legislature, OREgON GLOBAL WARMING COMM'N (2017) [hereinafter Biennial Report to the Legistlature], https://static1.square space.com/static/59c554e0f09ca40655ea6eb0/t/59dd4984a8b2b090a38f07a1/150767451

3035/2017-OGWC-Legislative-Report.pdf (explaining a bleak picture of the current state of the climate environment in Oregon and strenuously argues for immediate action).

15 See U.S. CONST. amend. V (significant limitations on the regulation of real property); U.S. CONST. amend. XIV (due process clause); OR. CONST. art. I $\S \S 18,20$ (takings and equality of privileges and immunities clauses of the Oregon Constitution).

16 The Oregon Department of State Lands, which largely administers public trust properties, describes the public trust doctrine as follows:

The rules controlling public use of the submerged and submersible land underlying state-owned waterways are simple. The Public Trust Doctrine gives you the right to use state-owned (or what are also termed "navigable") waterways (including submerged and submersible lands) for a wide variety of authorized uses including navigation, fisheries, recreation and commerce.

Navigability, OREGON.GOV., http://www.oregon.gov/OSMB/boater-info/Pages/Navigabi lity.aspx (last visited Apr. 8, 2018); see also Michael B. Huston \& Beverly Jane Ard, The Public Trust Doctrine in Oregon, 19 ENVTL. L. 623 (1989) (exploring the extent to which the public trust doctrine remains controversial and somewhat unexplored); Michael C. Blumm \& Doot, Oregon's Public Trust Doctrine: Public Rights in Waters, Wildlife, and Beaches, 42 Envtl. L. 375 (2012); Op. Att'y Gen. 8281 (Apr. 21, 2005); State Land Board v. Corvallis Sand \& Gravel, Co., 429 U.S. 363 (1977) (discussion of the State of Oregon).

17 State ex rel. Thornton v. Hay, 254 Or. 584, 587-91, 462 P.2d 671, 673-75 (1969) (using the British doctrine of custom to reserve the dry sand areas of beaches for public use). The United States Supreme Court denied certiorari, over the dissents of Justices Scalia and O'Connor, to a related challenge. See Stevens v. Cannon Beach, 317 Or. 131, 854 P.2d 449 (1993), cert. denied, 510 U.S. 1207 (1994). The Court has also shown regard for state property law, though its most recent opinion shows an aversion to change that may have constitutional implications. Stop the Beach Renourishment, Inc. v. Fla. Dep't of Envtl. Prot., 560 U.S. 702, 742 (2010). 
increase the resiliency of the response to climate change and its effects. $^{18}$

\section{B. What Must Be Done}

Assuming the responses are reasonable and there is a sense of urgency within the community, it is likely that Oregon has the tools under its planning and property law regimes to meet the challenges of climate change. Some areas where we believe increased responses will be needed include the following:

- Rural and natural resource areas-One expected result of changing weather patterns is an overall reduction of rainfall, which will have impacts on the state's agricultural and forest industries. ${ }^{19}$ Agricultural practices may have to change and treeplanting patterns may require alteration.

- Urban areas - Climate change will also cause a shift in urban transportation patterns. Energy consumption in residential and commercial buildings will be affected, and energy generation will move from fossil fuel to renewables. Less land may be available for ornamental gardens, and plant varietals used in bioswales and urban greenways may change to those that require less water. ${ }^{20}$ In addition, Oregon's relatively cooler weather may attract "climate refugees" from other states, due to fires, heat, drought, and water shortages, thereby changing population projections and land needs for the twenty-year period on which local plans are based. ${ }^{21}$ Moreover, climate change will alter a city's ability to provide economic and efficient public services to

18 See Borough of Harvey Cedars v. Karan, 70 A.3d 524 (N.J. 2013) (allowing an offset to an eminent domain award for an easement to construct a beachfront protective structure to safeguard the condemned property by the value of the structure to that land). There appears to be no impediment for the use of this method to finance local improvements. See OR. REV. STAT. ANN. §§ 223.205-.295 (West 2018).

19 See Barbara Bentz \& Kier KlePzig, Bark BeEtles and Climate Change in THE UNITED STATES, U.S. DEP'T OF AGRIC., U.S. ForEST SERV. (2014) (linking climate change to the recent infestations of bark beetle, which has had a profound effect on one of Oregon's major industries).

20 Renee Cho, How Plants Could Impact Global Warning, COLUMBIA UnIV. EARTH INST. (Feb. 12, 2011), http://blogs.ei.columbia.edu/2011/02/12/how-plants-could-impact -global-warming/.

21 See OR. ADMIN. R. 660-015-0000(14) (2003) (requiring that urban planning be based on a 20 -year forecast for each urban area). 
residents, and will likely give rise to more compact urban development. $^{22}$

- Potential hazards-Changing weather patterns will add to the catalogue of potential hazards and disasters that face the statefor example, coastal storms are more likely. ${ }^{23}$ Drought will be a likely concomitant of climate change, especially in the southern and eastern regions of the state. ${ }^{24}$

Moreover, climate change will have impacts on the economy of the state outside of the natural resource area. For example, the availability of water has allowed the silicon industry to expand, but water may become less available in the near future. ${ }^{25}$ Additionally, overfishing practices may add to changes in currents and obstacles to access to spawning areas to reduce the fishing industry. ${ }^{26}$ One possible change that the State may

\footnotetext{
22 Compact urban development is an objective of Goal 14. Id. Establishment of an urban growth boundary requires "local governments [to] demonstrate that needs cannot reasonably be accommodated on land already inside the urban growth boundary." Id. Moreover, expansion of an urban growth boundary under the Goal requires, inter alia, "[e]fficient accommodation of identified land needs; and [o]rderly and economic provision of public facilities and services." Id. Efficient provision of public services and facilities is also a principal theme of Oregon Statewide Planning Goal 11, Public Facilities and Services. OR. Admin. R. 660-015-0000(11). See generally Sullivan, A Timely, Orderly, and Efficient Arrangement of Public Facilities and Services-The Oregon Approach, 49 WillameTte L. REV. 411 (2013).

23 National Climate Change Report in the United States: Northwest: Coastal Vulnerabilities, U.S. Glob. CHANGE RESEARCH PROGRAM (2014), https://nca2014.global change.gov/report/regions/northwest\#statement-17000.

$24 I d$.

25 Water Resources, OR. Climate CHANGe ReSEARCH INST., http://www.occri.net /pnw-impacts/water-resources/ (last visited Apr. 8, 2018). Oregon State University’s Oregon Climate Change Research Institute, in its assessment of climate change on Pacific Northwest Water Resources, has projected less water available for all uses as a result of climate change:

The most visible and direct effect of a warmer world on our region's hydrological cycle will be on the snowpack. For basins whose winter snowpacks are historically near the melting point of water, such as those in Cascades, the consequences are greater: increased and more variable streamflow in winter, and decreased streamflow in late spring and summer.

Id.

26 Climate Impacts in the Northwest, U.S. EnVTL. Prot. AGENCY, https://19january 2017 snapshot.epa.gov/climate-impacts/climate-impacts-northwest_html (last visited Apr. 9, 2018) (This website is historical material reflecting the EPA website as it existed on January 19, 2017).
} 
consider is to use the basalt formations along the Columbia River for carbon sequestration. ${ }^{27}$

- Energy-Water scarcity caused by climate change may affect the electrical grid system that supports the state's aluminum industry, potentially prompting the state to review more expensive energy alternatives. ${ }^{28}$ While Oregon does not have a nuclear energy facility, it is part of a system that relies on nuclear energy and may need to plan for such facilities in the future. While a major coal-fired generation facility will close in 2020 , there remains the question as to what combination of conservation and substitute energy sources will be used. ${ }^{29}$ The use of solar and wave energy are viable alternative prospects for the state. ${ }^{30}$

- Coastal Areas - The impacts of climate change along the coastal areas of the state are also of concern as sea level rise occurs and impacts the delicate mix of saline and fresh water in estuaries, on which estuarine fauna and flora depend..$^{31}$ There is also a call for beachfront protective devices to be implemented in order to stabilize coastal dunes and shore lands. ${ }^{32}$

27 If we are to reach and maintain protection from climate change, we must limit $\mathrm{CO}_{2} \mathrm{e}$ in the atmosphere to $350 \mathrm{ppm}$. As we are now passing $400 \mathrm{ppm}$, we have to take out some of it and put it back in the ground.

28 Climate and the Aluminum Industry, GREENBIZ, https://www.greenbiz.com /research/report/2006/02/27/climate-and-aluminum-industry (last visited Apr. 9, 2018) (explaining that in addition to its own air quality impacts, the aluminum industry uses large amounts of electricity, which is connected to its location in Oregon because of the water power resources of the Pacific Northwest). Id. If those flows are reduced, the industry becomes less viable. $I d$.

29 Stacy Feldman, Early Closure of Oregon's Only Coal-Fired Power Plant Has National Implications, INSIDE CLIMATE NEWS (Jan. 18, 2010), https://insideclimatenews .org/news/20100118/early-closure-oregons-only-coal-fired-power-plant-has-national-im plications.

30 Alicia Healy, Clean Energy developments in Oregon, Nw ENERGY COALITION (Jan. 7, 2016), http://nwenergy.org/news/clean-energy-developments-in-oregon/ (explaining that these solutions are part of an overall plan to pry the state off its dependence on coal).

31 Ruggerio, P. et al., Impacts of Climate Change on Oregon's Coasts and Estuaries, U.S. ENVTL. PROT. AGENCY, (2011), https://cfpub.epa.gov/si/si_public_record_report.cfm ?dirEntryId=231987\&simpleSearch $=$ \&searchAll=climate\%20 change; Rick Cooper, How will climate change impact Oregon estuaries?, OR. STATE UNIV., http://seagrant.oregon state.edu/feature /how-will-climate-change-impact-oregon-estuaries (last visited Apr. 8, 2018).

32 Or. DeP'T Of LANd Conservation And DeV., Climate Ready Communities: A STRATEGY FOR ADAPTING TO IMPACTS OF ClimATE CHANGE ON THE OREGON COAST 14 (2009) [hereinafter CLIMATE READY COMMUNITIES]. The state's policy of generally not allowing further beachfront protective structures is justified as follows: 
Assuming climate change is inevitable, measurable impacts on Oregon will include: less snowfall, faster and earlier runoff, increased summer water shortages, a higher likelihood of bark beetle infestation in Oregon's forests, sea level rise, bigger storm surge impacts, and more frequent forest and range fires. ${ }^{33}$ Like King Canute facing the tide, we cannot command away these physical phenomena. Realistically, there are only two responses to climate change: mitigation and adaptation. Let us proceed now to an examination and evaluation of the tools available to the state in dealing with climate change.

\section{I}

\section{OREgon PROPERTY LAW AND CliMATE CHANGE}

\section{A. Property Law Foundations}

Property has been the subject of man's thoughts and desires throughout history. It has also been the subject of philosophy and law in western society, especially since 1215 when the Magna Carta was purported to resolve property conflicts between a king and those nobles who wanted stable rights to use of land. ${ }^{34}$

While the struggle over property rights between the crown and those occupying lands through title granted by the crown continued

Shore protection improvements: Some portions of Oregon's ocean shorelines have been armored against erosion from ocean waves, primarily in front of properties developed before 1977. As shorelines erode landward in response to higher sea level and storms, armored properties are at risk of becoming peninsulas, then islands, and then overtopped. An increase in significant wave heights is likely to damage or cause failure of some hardened shorelines, potentially resulting in damage to nearby unprotected property and infrastructure.

Id.

33 See Hal Bernton, Northwest Forests Will Get More and Bigger Fires with Climate Change, SEATTLE TIMES (Sept. 11, 2017), https://phys.org/news/2017-09-northwest-for ests-bigger-wildfires-climate.html.

34 English translation of Magna Carta, BRITISH LIBRARY (July 28, 2014), http://www .bl.uk/magna-carta/articles/magna-carta-english-translation. Much of the Magna Carta resolves disputes between the monarch on the one hand and the church and landed barons on the other. $I d$. The most significant section of that document today is section 39 , which forms the basis for what is now referred to as "due process" and is the intellectual basis for the Takings Clause of the Fifth Amendment to the federal Constitution:

No free man shall be seized or imprisoned, or stripped of his rights or possessions, or outlawed or exiled, or deprived of his standing in any way, nor will we proceed with force against him, or send others to do so, except by the lawful judgment of his equals or by the law of the land. 
for centuries thereafter, ${ }^{35}$ the notion of land ownership under general law gradually took hold. King Henry VIII dissolved the abbeys and gave church lands to his supporters, thus reinforcing royal sovereignty as well as a sense of entitlement in the landowner and his or her successors. ${ }^{36}$ When royal power again reasserted itself and threatened the legal and social order to which landowners and merchants had become accustomed, the Glorious Revolution of 1689 to 1690 sent King James II into exile and changed the architecture of the polity by parliamentary adoption of the Bill of Rights. ${ }^{37}$ The Bill of Rights provided both additional civil rights and stability of property, and the legislation was accepted by the new co-monarchs, William and Mary. ${ }^{38}$

The philosopher John Locke justified the Glorious Revolution in a way which sounds much like the rationale for the American Revolution, and spoke of real property in a way which forecasts modern real estate law. ${ }^{39}$ In particular, Locke established the theory that property rights are established by social compacts, which establish and maintain a regime of private property. ${ }^{40}$

\footnotetext{
$35 I d$.

$36 \mathrm{Id}$.

$37 \mathrm{Id}$.

38 See generally Bill of Rights of the United States of America (1791), BILL OF RiGHTS
} INST., http://www.billofrightsinstitute.org/founding-documents/bill-of-rights/ (last visited Apr. 9, 2018).

39 Alex Tuckness, Locke's Political Philosophy, STAN. ENCYCLOPEDIA OF PHILOSOPHY, https://plato.stanford.edu/entries/locke-political/ (last revised Jan. 11, 2016). Locke set three restrictions on the accumulation of property in the state of nature: "1) one may only appropriate as much property as one can use before it spoils (Two Treatises $2.31), 2$ ) one must leave 'enough and as good' for others (the sufficiency restriction) (2.27), and 3) one may (supposedly) only appropriate property through one's own labor (2.27)." Id.

40 John Locke, Of Property, The Second Treatise of Civil Government Const. SoC'Y, ch. V, $\S 25(1690)$. In establishing a theory of property consistent with the Bible and the understood contract the people had with their King, Locke said:

I will not content myself to answer, that if it be difficult to make out property, upon a supposition that God gave the world to Adam, and his posterity in common, it is impossible that any man, but one universal monarch, should have any property upon a supposition, that God gave the world to Adam, and his heirs in succession, exclusive of all the rest of his posterity. But I shall endeavour to shew, how men might come to have a property in several parts of that which God gave to mankind in common, and that without any express compact of all the commoners.

Id. Locke went on to say that when men invested labor in land, the understood compact evolved into property rights. Id. at ch. V, $\S \S 28,45$; see also Tuckness, supra note 38 . 
Another thinker who influenced modern Anglo-American concepts of property was Sir William Blackstone, a British judge who attempted to summarize the state of the common law in his Commentaries on the Laws of England. ${ }^{41}$ Like the Bill of Rights, Blackstone's Commentaries focused on the tension between private property rights, public rights, and regulations.

The law of property has also been influenced by two other schools of thought that emerged after the United States gained independence from the United Kingdom. The first was the concept of utilitarianism, which was advanced by the nineteenth century English philosopher Jeremy Bentham. Under a utilitarian system, advocated Bentham, the primary objective of the state should be utility, i.e., the greatest good for the greatest number of people. ${ }^{42}$ The emphasis on social utility brushed aside accepted doctrine on all manner of issues, ${ }^{43}$ and had a profound effect on British concepts of property. The second school of thought to influence modern property law was that of Modern British Positivism, which found no necessary relationship between law and morality, so that practically, law retained its authority regardless of perceptions of morality. ${ }^{44}$ While these schools of thought lacked the descriptive consensus held by the Magna Carta, the Bill of Rights, William Blackstone and John Locke, they did influence property theorists who disagreed with a system of property rights based on natural law. ${ }^{45}$

41 See generally Blackstone's Commentaries on the Laws of England, YALE L. SCH., http://avalon.law.yale.edu/subject_menus/blackstone.asp (last visited Apr. 8, 2018).

42 For a discussion of Bentham's greatest good or greatest happiness principle, see J.H. Burns, Happiness and Utility: Jeremy Bentham's Equation, 17 UTILITAS 1, 46 (2005), https:/www.cambridge.org/core/journals/utilitas/article/happiness-and-utility-jeremy-ben thams-equation/1BE48AA389161E1F676033457141BB1A.

43 Jeremy Bentham, Anarchical Fallacies, NONSENSE UPON STILTS: BENTHAM, BURKE AND MARX ON THE RIGHTS OF MAN (Jeremy Waltron ed., 1987) (asserting there is no such thing as a natural right). "That which has no existence cannot be destroyed - that which cannot be destroyed cannot require anything to preserve it from destruction. Natural rights is simple nonsense: natural and imprescriptible rights, rhetorical nonsense,nonsense upon stilts." Id. at 62 .

44 See, e.g., H.L.A. Hart, Positivism and the Separation of Law and Morals, 71 HARV. L. REV. 593 (1958).

45 The tension between classic natural law theory and emerging seventeenth century rationalism that emerged into utilitarianism is illustrated in Thomas L. Pangle, Natural Law Theory and the Bill of Rights, NATURAL LAW, NATURAL RIGHTS AND AMERICAN CONSTITUTIONALISM (2018), http://www.nlnrac.org/printpdf/100. Regardless of their views of utilitarianism or positivism, property law theorists acknowledge the influence of these schools of thought on modern property law. Abraham Bell \& Gideon Parchomovsky, A Theory of Property, 90 CORnEll L. REV. 531, 531 (2005); see Ra Epstein, The 
The most compelling and pragmatic pronouncement on the relationship of property and law comes from Hernando de Soto, a Peruvian economist who opines that modern democratic societies came about and will continue only as a result of a robust, defensible, system based on private ownership of real property. ${ }^{46}$

The legal system as it relates to real property has developed slowly, resolving the details of property ownership in the conditions of each society. However, those conditions constantly change and with it the underlying premises of real property law must also be reviewed to determine appropriate public policy in light of these changes. The most significant changes would seem to make the almost extreme emphasis on private property rights. If this change is not an anachronism, it is an impediment to rational problem solving.

The law of real property is, at its heart, a conservative doctrine generally supporting the use, in particular the beneficial use, of real property, conditions based on that use, and prior decisions on the application of those systems. Core property doctrines, such as adverse possession, prescriptive easement and the prior appropriation doctrine in water law all support these concepts of beneficial use and support for current conditions. A review of the philosophy of law and an examination of court decisions appear to be based on concepts of private ownership, use and control that have little, if any, recognition of the public interest as it relates to real property (including land and water). The shortcoming of this approach is demonstrated by what has become known as the "tragedy of the commons" which grew out of the term, probably coined originally by William Forster Lloyd in 1833 and later used by Garrett Hardin, to denote a situation where individuals acting independently and rationally according to the self-

Utilitarian Foundations of Natural Law, 12 HARV. J. L. \& PUB. POL'Y 711 (1989); Brian Leiter, Marx. Law, Ideology, Legal Positivism, 101 VA. L. REV. 1179 (2015). See also Robert McGee, Property Rights v. Utilitarianism: Two Views of Ethics, 27 BARRY UnIV. REASON PAPERS 87 (2004); Thomas W. Merrill \& Henry E. Smith, The Morality of Property, 48 WM. \& MARY L. REV. 1849 (2007); Henry Smith, Custom in American Property Law: A Vanishing Act, 48 TEX. INT'L L.J. 507 (2013).

46 De Soto's principal works are HERNANDO DE SOTO, THE OTHER PATH (1989) and HERNANDO DE SOTO, THE MYSTERY OF CAPITAL: Why CAPITALISM TRIUMPHS IN THE WEST AND FAILS EVERYWHERE ElSE (2000). Soto argues that strongly based property rights allow for accumulation of capital and social stability. See also Claudia Williamson, The Two Sides of De Soto: Property Rights, Land Titling and Development, in THE ANNuAl ProceEdings of the Wealth and Well-Being of NATIONS 98 (Emily Chamlee-Wright ed., 2010). 
interest of each behave contrary to the best interests of the whole group by depleting some common resource. ${ }^{47}$

This prioritization of the individual over the community was recently demonstrated in a case heard before the U.S. Supreme Court that concerned a beachfront property restriction based on the need to protect a coastal area from significant damage from hurricanes and tropical storms. ${ }^{48}$ The Supreme Court in Lucas v. South Carolina Coastal Council essentially ruled that the private right in such property was paramount to the public's interest in protecting the coast unless a public right inhered in the title or there was a common-law nuisance. ${ }^{49} \mathrm{We}$ now live in an era when these decisions and the underlying philosophy may not be adequate for the future. The conditions of natural resource depletion, especially water, and the effects of climate change require a new approach to these issues.

\section{B. Water Rights}

One area of property law where new environmental realities may provide some guidance for future changes in the law is in the use and enjoyment of water. Until recently, the law of riparian rights and the law of prior appropriation were the basis for the beneficial use and enjoyment of water. In the eastern United States, the owner of riparian rights - those whose land borders or contains natural watercourses - holds the beneficial rights to the use and enjoyment of the water. $^{50}$ In the western United States, where water was less available and societal and cultural uses began to clash, the doctrine of

\footnotetext{
47 Garrett Hardin, The Tragedy of the Commons, 162 SCI. 1243, 1244 (1968). Hardin adds:

The tragedy of the commons develops in this way. Picture a pasture open to all. It is to be expected that each herdsman will try to keep as many cattle as possible on the commons. Such an arrangement may work reasonably satisfactorily for centuries because tribal wars, poaching, and disease keep the numbers of both man and beast well below the carrying capacity of the land. Finally, however, comes the day of reckoning, that is, the day when the long-desired goal of social stability becomes a reality. At this point, the inherent logic of the commons remorselessly generates tragedy.

48 Lucas v. S.C. Coastal Council, 505 U.S. 1003 (1992).

49 Id. at 1029-32.

50 See U.S. v. Gerlach Live Stock Co., 339 U.S. 725, 745, 751-52 (1950).
}

Id. 
prior appropriation came into existence, placing an emphasis on the beneficial use of water. ${ }^{51}$

While the details of the two-systems application vary based on state law, it is clear that the original doctrines are being eroded by governmental control of water. This control arises due to the essential nature of the water, its diminished availability, and the public necessity for control. ${ }^{52}$

While certain vested rights are protected, the "ownership" of water by the public is a new concept set forth in the statute. Due to statutory law, the system now requires permits, with some exceptions, to be acquired. ${ }^{53}$ The permit conditions generally require continued beneficial use, taken from a specific location and applied to limited areas as defined in the permit. ${ }^{54}$ Historically this system is adequate for most purposes. However, a recent drought brought to light the fact

51 Devin Schwartz, Klamath Tribes and Ranchers Seek Water Solutions in New Agreement, OR. PUBliC BROAdCASTING (Mar. 5, 2014), http://www.opb.org/news/article /klamath-tribes-and-ranchers-seeks-to-water-solutio/.

An agreement announced Wednesday between ranchers and Native American tribes seeks to resolve contentious water rights issues in the Klamath Basin, a droughtridden region spanning southern Oregon and northern California. Amidst a deep drought last summer, the Klamath Tribes and the federal government called on their senior water rights - meaning they received access to limited water supplies. Id.

As a result, irrigation water was cut off to thousands of acres of Klamath Basin ranchland. This created millions of dollars in losses. The new agreement seeks reduced water demand by ranchers, along with increased river restoration and economic development for the Klamath Tribes.

Id. (providing an example of this situation as the ongoing dispute in the Klamath Basin of Oregon in a conflict that pits ranchers, native American tribes, and environmentalists against each other).

52 OR. REV. STAT. ANN. § 537.110 (West 2018). For example, Oregon law, with respect to water, provides that "[a]11 water within the state from all sources of water supply belongs to the public." Id.

Subject to existing rights, and except as otherwise provided in ORS chapter 538, all waters within the state may be appropriated for beneficial use, as provided in the Water Rights Act and not otherwise; but nothing contained in the Water Rights Act shall be so construed as to take away or impair the vested right of any person to any water or to the use of any water.

Id. $\S 537.120$. Taken together, water is declared a common resource, but is subject to "vested rights."

53 Id. § 540.145(3) (West 2018).

54 Id. $§ 540.505$ (West 2018). 
that the number of vested rights and permitted uses were sufficient to drain some rivers completely, several times over. ${ }^{55}$

Given that an occasional drought, flood, or other unusual condition can bring the legal rights of owners into question, what if the "occasional" becomes commonplace and areas become subject to drought or to flooding on a regular basis?

The reality of climate change is irrefutable; it raises various issues regarding all aspects of real estate law and may require different approaches from the courts or policy decisions from our legislature. Those responses will be required due to increases or decreases in the volume of rain, melting of icebergs, or any other phenomenon that changes the location of rivers, lakes, or oceanfront.

A proposed response to this issue is to build on the concept identified in section 537.110 of the Oregon Revised Statutes, in which an entity such as the Water Resources Board must necessarily allocate the available water (with guidance from the legislature) among the competing interests of agriculture, municipal and domestic use, recreation, and fish. ${ }^{56}$ Still, the problem of balancing this right of public ownership against the "vested rights" recognized in section 537.120 of the Oregon Revised Statutes remains. ${ }^{57}$ For example, Oregon requires the payment of money in exchange for rights taken or voluntarily relinquished for public benefit.

\section{Boundary Law Issues}

The basic legal issues that are in play in this category are few and simple. However, they are the most inimical to the rapid changes resulting from climate change. When it comes to boundary changes that result from expanding or contracting water courses, the rule is that if they are slow and natural, the boundary will follow the changes; however, if the movement is either unnatural (dam, rip rap, or other diversion) or quick (e.g., flood) the boundary will stay in place. ${ }^{58}$ The other significant doctrine to consider is the Public Trust Doctrine, which places ownership of "navigable" waters with the

\footnotetext{
55 SUMMARY OF DROUGHT FOR OREgON, NAT'L INTEGRATED DROUGHT INFORMATION INFO. SYS., https://www.drought.gov/drought/states/oregon (last visited Apr. 8, 2018); see GeORge H. TAYlor \& RAymond R. HATton, THE OREgON WEATHER BOOK: A STATE OF EXTREMES 195-204 (1st ed. 1999).

56 OR. REV. STAT. ANN. § 537.110 (West 2018).

57 Id. $§ 537.120$ (West 2018).

58 State of Or. by and through State Land Bd. v. Corvallis Sand and Gravel, 272 Or. 545, 538 P.2d 70 (1975).
} 
federal government, or the various states, as governed by the individual admission acts. ${ }^{59}$

The law noted above has evolved through the common law over the years and has changed very slowly, responding only to individual, factual issues - not something as significant as climate change. An example of this change is the slowly evolving definition of "navigable," which differs from state to state, and court to court, which has had the effect of bringing more watercourses within the ownership and jurisdiction of the various states or federal government. ${ }^{60}$

This issue is significant to Oregon. Under Oregon law, for nonnavigable streams, the riparian owners own the bed and banks to the thread of the stream. In navigable waters, the state, along with other states, owns the bed and banks in accordance with the equal footing doctrine, which was in place when Oregon was admitted to the Union in 1859. The Clean Water Act required permits for discharges of contaminants into Waters of the United States and delegated responsibility to the States, including Oregon. ${ }^{61}$ To clarify the Supreme Court opinions regarding significant nexus and permanently flowing streams, the Obama administration's Environmental Protection Agency and Corps of Engineers issued a "Waters of the United States" rule, which has been placed under review by a February 17, 2017, executive order of President Donald Trump. ${ }^{62}$

It is important to note that the apparent, though not explicit, policy is to "let nature take its course," and the affected property owners can gradually (the key word is "gradually") accommodate themselves to the change. Also implicit in this policy, is the concept that the sudden and violent changes are so infrequent that the individual property owners and the courts are able to absorb the consequences. However, with sudden and violent climate changes these underlying assumptions will no longer apply and will force significant responses by the courts and legislature.

A potential issue concerns whether the change is a "natural" result of climate change, or whether a sufficient enough implication of

59 E.g., An Act for the Admission of Oregon into the Union, 11 Stat. 383, § 2 (Feb. 14, 1859).

60 See New "Waters of the United States" Definition Released, NAT'L ASS'N OF COUNTRIES (2014), http://www.naco.org/sites/default/files/documents/Waters-of-the-US -County-Analysis.pdf.

61 See, e.g., Rapanos v. U.S., 547 U.S. 715 (2006).

62 Exec. Order No. 13778, 82 C.F.R. § 12497 (2017). 
human activity exists to take it outside this fact situation, and have the courts determine ownership based on the prior location of any boundary. Notwithstanding this potential, it is anticipated that the courts would be both willing and able to side step the issue of what is "natural," and determine the outcome of cases based on the other factors identified below. An example of sidestepping or ignoring the issue of "natural" is the absence of any significant cases involving changes in tidal currents based on the construction of jetties, which are far from "natural." 63

If this analysis is correct, the first issue to be determined is whether the change was either "quick," leaving boundaries in place, or "slow," allowing boundaries to move. ${ }^{64}$ As noted, the law is historical and the slow movement is typically one of multiple years; however, given current changes, the question will be whether significant change occurring over a few months or over a year or two, will qualify as "quick" or "slow." There is no precedent to guess how courts might ultimately rule, and there will most likely be significant variation in decisions across jurisdictions until the initial cases are decided.

State of Oregon Land Board v. Corvallis Sand \& Gravel Co. offers a clear illustration of what can happen if the rulings consistently identify the movements as "sudden," which results in boundaries remaining in place. $^{65}$ In that particular instance, following a significant and highly unusual flood condition, the Willamette River literally "jumped" its current course and relocated several hundred feet away. ${ }^{66}$ The plaintiff later began extracting aggregate from the "new" riverbed, which resulted in litigation when the State of Oregon asserted ownership of the riverbed pursuant to the Public Trust Doctrine, and sought to prevent the company from extracting the aggregate. ${ }^{67}$ The court in its ruling determined that the movement was "quick," and as such, the state's ownership was in the old, now dry, riverbed. ${ }^{68}$ The clear result was the loss of control over the portion of the otherwise navigable river, and the significant assets located within

63 But see Winston Bros. Co. v. Galloway, 168 Or. 109, 121 P.2d 457 (1942).

64 State of Or. ex. rel. State Land Bd. v. Corvallis Sand \& Gravel, 272 Or. 545, 538 P.2d 70 (Or. 1975).

65 State of Or. by and through State Land Bd. v. Corvallis Sand \& Gravel Co., 18 Or. App. 524, 538-39, 526 P.2d 469, 476 (Or. Ct. App. 1974).

66 Id. at 533, P.2d at 474.

67 Id. at 536-37, P.2d at 475.

$68 \mathrm{Id}$. at $540-41, \mathrm{P} .2 \mathrm{~d}$ at 477. 
the riverbed. ${ }^{69}$ It takes little imagination to determine the outcome of various decisions based on this case when climate change results in numerous, similar situations that result in loss of control of the watercourses and the assets they contain.

In Sea River Properties, LLC v. Parks, the Oregon Supreme Court sidestepped the issue of lateral accretion, which undoubtedly will have to be decided as climate change becomes more pronounced. ${ }^{70}$ The doctrine of lateral accretion has been adopted by a number of states. ${ }^{71}$ A brief review of the facts illustrates the doctrine and its application. ${ }^{72}$ The properties of the two parties were in front of the Nehalem River, where it flows into the Pacific Ocean. ${ }^{73}$ The northern property, east of the river, owned by defendant Parks, is comprised of Government Lot 4, as originally identified and laid out in the initial rectangular survey system done in Oregon. ${ }^{74}$ Based on the facts as found by the trial court, the Nehalem river moved southerly and then reverted to a point north of the boundary lien of government lot 4, based on the slow and gradual accretion located within the plaintiff's property. ${ }^{75}$ The plaintiff's claim of ownership would have, effectively, eliminated the original government lot boundary. ${ }^{76}$ If the court had applied the "lateral accretion doctrine," the original line would be adhered to regardless of the accretion. As noted, the court sidestepped the application of the doctrine; however, once again it takes little imagination to identify the various problems that could occur in future decisions if this doctrine is not adopted by the courts.

New Jersey's implementation of what is termed a "rolling easement" is instructive of the problem created by the traditional law of boundaries as it impacts attempts at mitigating the effects of climate change, especially in the aftermath of Hurricane Sandy. ${ }^{77}$ As used in the New Jersey context, a rolling easement is one that allows the government to enter on the land to take such action as is necessary

\footnotetext{
$69 \mathrm{Id}$.

70 Sea River Props., LLC v. Parks, 355 Or. 831, 854, 333 P.3d 295, 310 (2014).

$71 \mathrm{Id}$. at $851, \mathrm{P} .3 \mathrm{~d}$ at 308.

72 Id. at $852-54$, P.3d at $309-10$.

$73 \mathrm{Id}$. at 834, P.3d at 298.

$74 \mathrm{Id}$.

75 Id. at $834-835$, P.3d at 298-99.

76 Id. at 843 , P.3d at 304.

77 See Kevin J. Mahoney, Mitigating Myopia: Climate Change, Rolling Easements and the Jersey Shore, 44 SETON HALL L. REV. 1130, 1131-35 (2014).
} 
to protect the upland shore. ${ }^{78}$ Unlike the traditional easement, which stays in place, a rolling easement will "move" landward in the event the land becomes inundated. ${ }^{79}$ The most dramatic application could be a partial or even complete removal of a private improvement on the premises. The state of New Jersey negotiated with sea front owners of land; however, as can be expected, several did not agree. ${ }^{80}$ In contrast, another approach was made in Borough of Harvey Cedars v. Karan. ${ }^{81}$ In Karan, the borough acquired a portion of the land through eminent domain and the trial involved the basic question of appropriate compensation. ${ }^{82}$ In the opinion of the Army Corps of Engineers the Karan property had a $56 \%$ chance of being completely destroyed within the next 30 years and the beach dune, which was to be provided, would offer significant protection not only to Karan, but the community at large, although affect the view from the residence. ${ }^{83}$ The question to be determined was whether the testimony regarding the general benefit was permissible for the jury to hear and consider since only "special benefits," not "general benefits" are compensable. ${ }^{84}$ The court instead focused on the concept that the amount in question must be "reasonably calculable." 85 The Karans ultimately settled with the Borough for one dollar. ${ }^{86}$

The potential outcomes in this case offer an interesting contrast. If the government did nothing and the property was partially or totally destroyed, it would owe nothing; however, since the government did take action, the property owners are owed the calculable cost of the taking. Government inaction is generally not politically feasible. The ultimate outcome, the insignificant settlement in Karan, afforded the State of New Jersey more leverage in its negotiations for future easements.

\footnotetext{
$78 I d$.

$79 \mathrm{Id}$.

$80 \mathrm{Id}$.

81 Borough of Harvey Cedars v. Karan, 70 A.3d 524 (N.J. 2013).

82 Id. at 526.

$83 \mathrm{Id}$. at 529.

$84 \mathrm{Id}$.

85 Id. at 543-44.

86 See MaryAnn Spoto, Harvey Cedars couple receives \$1 settlement for dune blocking ocean view, NJ.COM (Sept. 25, 2013, 1:21 PM), http://www.nj.com/ocean/index.ssf/2013 /09/harvey_cedars_sand_dune_dispute_settled.html.
} 
In contrast, in Severance v. Patterson, ${ }^{87}$ a hurricane caused the vegetation line on a portion of Galveston Island to move significantly, creating a situation where the private landowners' property was now seaward of the vegetation line. ${ }^{88}$ The issue was whether the preexisting easement for public access on the "dry sand" area seaward of the vegetation line continued to encumber the land since the vegetation line had moved and the existing house interfered with public access. ${ }^{89}$ The Texas Attorney General argued that it "rolled" in accordance with the Texas Open Beaches Act (OBA), as an appellate court had ruled in Feinman v. State. ${ }^{90}$ However, the Texas Supreme Court did not recognize the doctrine of "rolling easements" and ruled that the land was not encumbered by the prior public access. In weighing the public and private rights, the court stated, "avulsive events such as storms and hurricanes that drastically alter pre-existing littoral boundaries do not have the effect of allowing a public easement to migrate onto previously unencumbered property." 91

Another significant issue within the purview of real property law is "riparian rights." Riparian rights are the rights available to a property owner by virtue of owning land either bordering or encompassing a significant water course or lake. ${ }^{2}$ These rights can be described as those identified by the right to control, as limited by the Public Trust Doctrine, ${ }^{93}$ and the right to withdraw and use the water for use on the

87 Severance v. Patterson, 370 S.W. 3d 705 (Tex. 2012).

88 Id. at 712.

89 Id. at 747.

90 Feinman v. State, 717 S.W.2d 106, 108, 111 (Tex. App. 1986).

91 Severance, 370 S.W.3d at 725.

92 Fitzstephens v. Watson, 218 Or. 185, 199, 344 P.2d 221, 228 (1959).

93 In the middle of 2017 there was much discussion in Oregon about Juliana. Juliana v. United States, 217 F. Supp. 3d 1224 (2016). In her November 2016 denial of the Government's motions to dismiss, Judge Aiken wrote:

This action is of a different order than the typical environmental case. It alleges that defendants' actions and inactions - whether or not they violate any specific statutory duty - have so profoundly damaged our home planet that they threaten plaintiffs' fundamental constitutional rights to life and liberty. A deep resistance to change runs through defendants' and intervenors' arguments for dismissal: they contend a decision recognizing plaintiffs' standing to sue, deeming the controversy justiciable, and recognizing a federal public trust and a fundamental right to climate system capable of sustaining human life would be unprecedented, as though that alone requires its dismissal. This lawsuit may be groundbreaking, but that fact does not alter the legal standards governing the motions to dismiss. Indeed, the seriousness of plaintiffs' allegations underscores how vitally important it is for this Court to apply those standards carefully and correctly.

Id. at $1261-62$. 
property (irrigation, recreation). With respect to bodies of water not considered "navigable"-i.e., not available or used for fishing, navigation, or commerce - the riparian ownership extends to the center of any such body of water. ${ }^{94}$ However, if a body of water is deemed navigable, the extent of ownership and control of the riparian owner generally ends at the mean high water line (except in selected parts of the Willamette River where riparian ownership can extend to the low water line). ${ }^{95}$ Corvallis Sand \& Gravel demonstrates how a sudden movement of a body of water can impact public or private ownership. ${ }^{96}$ However, no cases have dealt with more or less rapid accretion or reliction of a body of water as may be anticipated with the increasing impacts of climate change. Will current boundaries be adhered to, leaving the public in control of the assets? Or, will private ownership follow, thereby passing significant assets from public to private ownership? The answers ultimately depend on the various court decisions as to what constitutes "slow and natural" movement.

\section{Water and Its Use and Enjoyment}

The other issue may well be more significant - the right to divert control and use the water itself as it flows along or within the riparian owner's property. Although Oregon has adopted the common law prior appropriation doctrine (which is extant in most, if not all, western states) for determining priority rights, the state has a significant role in the registration and control of the use of water through statutory provisions and the Water Resources Board and Department. ${ }^{97}$ In essence, the law requires the approval of a given diversion point in the body of water and limitation of the use of water in both volume and location on the riparian premises. ${ }^{98}$ Any changes in the diversion point or benefitted property require prior approval from the Oregon Department of Water Resources. ${ }^{99}$

The significant change in the course of water flow resulting from climate change will result in a significant increase in the workload imposed on the Water Resources Board. It will be inundated by

94 Belmont v. Umpqua Sand \& Gravel, Inc., 273 Or. 581, 588-89, 542 P.2d 884, 889 (1975).

95 State of Or. ex rel. State Land Bd. v. Corvallis Sand \& Gravel Co., 18 Or. App. 524, 535-36, 526 P.2d 469, 474-75 (Or. Ct. App. 1974).

96 Id. at 540-41, 477.

97 See generally OR. REV. STAT. ANN. $§ \S 540.505-540.585$ (West 2018).

98 See id. $\S 540.505$.

99 Id. $\S 540.510(6)$. 
requests for revised diversion points and benefitted property changes resulting from the fact that diversion points are no longer feasible because they are now covered with or too far from the body of water to be useful. What happens to property that is now underwater or too far away to be useful? What policy factors will be utilized to grant (or deny) such changes? In the face of substantial changes, which factors are prioritized (public or private, essential personal needs, irrigation) and who makes these determinations? All of the issues identified above suggest that a comprehensive (legislative) approach to the underlying policy decisions may be the best response. As to the rights of owners to use water, they seem most susceptible to such comprehensive determinations, as there exists a history, a procedure, and resources to make such decisions. There are three levels at which this approach must be taken, two of which have little history to support them. Because nature does not follow national boundaries, the first level of cooperation must be at the international level, as exemplified by the Kyoto Protocol. ${ }^{100}$ Although it is possible, in some cases such as natural water sheds, to limit the cooperation to what may be referred to as regional, at least as far as the ocean is concerned, it must be international since virtually all countries are affected in one way or another by the ocean. While the Kyoto Protocol offers an example of potential international cooperation, it is far too dependent on the voluntary cooperation of individual countries, which, given political changes, can be problematic. In order for this to be successful there must be enforceable international treaties through institutions such as the International Court of Justice or an arbitration panel established by treaty. It is also clear that if this were to happen, it would require not only strengthening international institutions, but also weakening of national sovereignty. The treaty process would need to identify areas of essential cooperation (e.g., Pacific, Atlantic, Mediterranean, etc.), areas of mutual concern, and a fact-based response to identified problems.

Regional compacts or agreements, again based on issues of common concern, would supplement these. In the United States, this would also include agreements or compacts between the individual states based on common concerns.

100 See Kyoto Protocol to the United Nations Framework Convention on Climate Change, U.N. Doc FCCC/CP/1997/7/Add.1, 37 I.L.M. 22 (1998). 


\section{E. Boundary Issues}

As with water, the issue of boundaries also suggests that a comprehensive approach is necessary. However, boundary issues have a far smaller scope since it is entirely possible to regulate the rights of individuals in a different manner, in one country or state based on a different philosophy or balance of individual rights. For example, the legislature in Oregon may choose to continue to apply old rules, while California may decide to make wholesale changes based on a different philosophical approach to the issues.

It does seem that the old rules of boundary law would and could continue to be applied to those situations where the changes continue to be incremental. However, decisions as to how to apply the rules or not would need to be in place when dealing with periodic floods, which may vary in their intensity from time to time. Simply relying on the old rule of "the boundary stays in place" would seem misplaced when dealing with sustained flooding. States may have to make determinations as to the "permanency" of the periodic flooding in order to make ultimate determinations.

An example of how the Oregon legislature dealt with a tangential issue involving adverse possession is instructive as to what might be done. Until 1989, the concept of adverse possession was entirely based on judicial decisions with the underlying philosophy of Locke's concept of beneficial use; if one made beneficial use for an appropriate period of time, one could be deemed the owner. ${ }^{101}$ However, in 1989 the legislature substantially revised the law of adverse possession. ${ }^{102}$

101 Reeves v. Porta, 173 Or. 147, 149, 144 P.2d 493, 495 (1944).

102 OR. REV. STAT. ANN. $§ 105.620$ (West 2018) (amended 1989). The statute reads:

(1) A person may acquire fee simple title to real property by adverse possession only if:

(a) The person and the predecessors in interest of the person have maintained actual, open, notorious, exclusive, hostile and continuous possession of the property for a period of 10 years;

(b) At the time the person claiming by adverse possession or the person's predecessors in interest, first entered into possession of the property, the person entering into possession had the honest belief that the person was the actual owner of the property and that belief:

(A) By the person and the person's predecessor in interest, continued throughout the vesting period;

(B) Had an objective basis; and

(C) Was reasonable under the particular circumstances; and 
Although the requirements identified in that statute mirror the common law standards, the provisions of 1(b), in particular, and (2)(b) are additional requirements. ${ }^{103}$ These changes respond more directly to modern conditions of use and possession of real estate. While the legislative changes to the common law standard are relatively minor, it illustrates that changes could be made by the legislature in adopting boundary standards based on the common law of avulsion, relocation, navigability, and the like. ${ }^{104}$ For example, instead of the "slow and natural" change as utilized in judicial decisions, legislative boundary guidelines could be deemed "natural" although they may happen more quickly than in the past, so long as the legislative change is not based on other human factors. While the legislative guidelines cannot be precise and would depend on the courts applying guidelines to a given set of facts, the courts already play that role. ${ }^{105}$

Particular interest needs to be paid to the coastal areas. To some degree, Oregon courts and the state legislature have addressed coastal area needs by determining that the "dry sand area" of the coast, although owned by adjoining landowners, is available to the public for use and control. ${ }^{106}$ Opening up the area to public use and control can be the basis for additional control in dealing with particular coastal issues, such as those in Lucas v. South Carolina Coastal Council ${ }^{107}$ however, the takings decision will still stand.

(c) The person proves each of the elements set out in this section by clear and convincing evidence.

(2)(a) A person maintains "hostile possession" of property if the possession is under claim of right or with color of title. "Color of title" means the adverse possessor claims under a written conveyance of the property or by operation of law from one claiming under a written conveyance.

(b) Absent additional supporting facts, the grazing of livestock is insufficient to satisfy the requirements of subsection (1)(a) of this section.

(3) As used in this section and ORS 105.005 and 105.615, "person" includes, but is not limited to, the state and its political subdivisions as created by statute.

103 Id.

104 See, e.g., Bonnett v. State by \& through Division of State Land, 151 Or. App. 143, 949 P.2d 735 (1997).

105 See id.

106 State ex rel. Thornton v. Hay, 254 Or. 584, 598-99, 462 P.2d 671, 678 (1969).

107 See Lucas v. S.C. Coastal Council, 505 U.S. 1003 (1992). 


\section{F. Fundamental Decision}

There does appear to be at least one fundamental decision that needs to be made by governing bodies having jurisdiction over riparian or coastal areas: whether to actively alleviate the effects of global warming, such as through the construction of levees, dams, and jetties, or to take a more passive approach, allowing nature to take its course. One could do well to look at the experience of the Netherlands, which has dealt with the effects of what global warming may ultimately look like for the rest of the world - that is the rising sea levels. Historically, the Netherlands has relied on levees, windmills, and other water management tools to maintain and gain additional land. However, it recently modified its approach to more proactively identify areas that might be affected and make them compatible with rising water levels. ${ }^{108}$ This has entailed setting aside entire areas for future periodic flooding, including limiting or eliminating any development within areas that may be significantly harmed by flooding. ${ }^{109}$ The Netherlands' new approach has required a fundamental shift in thinking and comes at great financial cost to the public. ${ }^{110}$ However, the cost of evacuating or limiting access to areas may be far more cost effective than the cost of less reliable alternatives, as seen in Hurricane Katrina in New Orleans.

\section{G. Responses Generally}

As noted above, the responses to global warming will require a reevaluation of our approach to land and its ownership, a shift from individual ownership to that of the "commons" where there is a community of shared responsibility and assets. However, "ownership" issues cannot be addressed without significant limitation as imposed by the takings clause of the Fourteenth Amendment and article 1, section 18 of the Oregon Constitution. ${ }^{111}$ Such limitations are exemplified in many Oregon cases and other coastal commission cases across the country in which governmental action was deemed to have resulted in a taking of private property without just

108 See SAMEN Werken AAN EEN VeILIGer EN MoOI Rivierengebied, RUIMTE VOOR DE RIVIER, https://www.ruimtevoorderivier.nl/over-ons/ (last visited Feb. 8, 2018).

109 Id.

110 Id.

111 OR. CONST. art. $1, \S 18$. 
compensation. ${ }^{12}$ The Supreme Court, in Kelo v. City of New London, ${ }^{113}$ affirmed the authority of New London, Connecticut, to take and transfer non-blighted private property by eminent domain in order to develop a more viable economic area. ${ }^{114}$ Notwithstanding this decision, there has been a response contrary to the reasoning in the Kelo case, and some states have passed legislation limiting the use of eminent domain. ${ }^{115}$ Regardless, Kelo does provide a legal basis for the utilization of eminent domain for larger public purposes in response to the issues created by severe weather, such as drought and floods.

Stop the Beach Renourishment $v$. Florida Department of Environmental Protection provides some support to government eminent domain action to protect the environment. ${ }^{116}$ In this case, the United States Supreme Court held that it was not a taking when the state of Florida added dry sand to submerged lands resulting in an accretion to those lands. ${ }^{117}$ The Court held that the upland owners did not have a right to continue contact with the water and that issues of accretion would be decided on the basis of the common law principles discussed above. ${ }^{118}$

Inherent in any exercise of eminent domain and the construction of public improvements, such as dikes, levees, and dams, is the financial cost. Funds are usually acquired through taxation. ${ }^{119}$ However, in those instances where the expenditures can be identified as protecting or benefiting a finite group, other forms of financing are available, most notably lien improvement districts. ${ }^{120}$ It is clear that in the current political climate, there is little appetite for additional governmental action and, in particular, additional taxes or levies may be problematic.

112 See Dolan v. City of Tigard, 512 U.S. 374 (1994); Nollan v. Cal. Coastal Comm'n, 483 U.S. 825 (1987).

113 Kelo v. City of New London, Conn., 545 U.S. 469 (2005).

114 Id. at $489-90$.

115 E.g., KAN. STAT. ANN. § 26-501 (West 2018).

116 Stop the Beach Renourishment, Inc. v. Fla. Dep't of Env't Prot., 560 U.S. 702 (2010).

117 Id. at 733 .

118 Id. at 732 .

119 James Monacell, Community Improvement Districts as a Tool for Infrastructure Financing, SMITH GAMBRELL \& RUSSELL LLP, http://www.sgrlaw.com/briefings/452/ (last visited Jan. 29, 2018).

120 See id. 


\section{H. Private Responses}

Responses include litigation between individuals or groups of individuals versus governmental bodies, such as the Court of Federal Claims litigation in Louisiana in which the parties alleged the federal government failed to protect the individuals harmed by the Katrina floods. ${ }^{121}$ Responses may also include actions by the upper levels of government against local officials who fail to adhere to standards and guidelines for the protection of local citizens from floods.

An example of local officials being held accountable for their failures is a French regional government's successful suit against the mayor and several local officials in La Faute-Sur-Mer for failure to comply with obligations suggested or imposed by the regional government. ${ }^{122}$ The city, which lies at the mouth of a river at its confluence with the ocean, failed to adopt protective land use practices, failed to adopt emergency response plans, and issued numerous illegal permits for the construction of housing, particularly in low lying areas. A major storm resulted in significant property loss and twenty-nine deaths. ${ }^{123}$ The mayor was found guilty of negligent homicide and sentenced to four years in prison, the planning director was fined 75,000-euro, and other governmental officials were held accountable with lesser fines. ${ }^{124}$ The matter is now on appeal. ${ }^{125}$

The foregoing does demonstrate that the courts are involved in the cost allocation of damages incurred as a result of climate change driven storms and flooding. However, the litigation has not resulted in a coherent philosophy of loss allocation and is driven by individual responses to loss.

121 See St. Bernard Par. Gov't v. United States, 121 Fed. Cl. 687, 690-91 (2015). Following an adverse ruling on damages, the United States appealed to the Federal Circuit (2016-2301 and 2373), where the case is pending. Jessica Anne Wentz, Government Officials' Liability After Extreme Weather Events: Recent Developments in Domestic and International Case Law, COLUM. L. SCH. SABIN CTR. FOR ClimATE CHANGE L.: CliMATE L. BLOG (Feb. 18, 2015), http://blogs.law.columbia.edu/climatechange/2015/02/18/govern ment-officials-liability-after-extreme-weather-events-recent-developments-in-domestic -and-international-case-law/comment-page-1/.

122 French Mayor Rene Marratier Jailed for Role in Deadly Flood, BBC NEWS (Dec. 12, 2014), http://www.bbc.com/news/world-europe-30453552.

123 French Mayor Jailed Over Floods that Left Twenty-Nine Dead, THE LoCAL (Dec. 12, 2014, 12:47), https://www.thelocal.fr/20141212/french-mayor-jailed-over-floods-that -killed-29.

124 Id.

125 Id. 
It is also probable that some of the burden of cost will be transferred to individuals who wish to live in a particular area or transfer their property. For example, if an area is susceptible to continuous flooding the only currently viable alternative is flood insurance, which is so expensive that the federal government must subsidize it. ${ }^{126}$ The recent floods in various parts of the United States have led to the depletion of the flood insurance fund. ${ }^{127}$ The BiggertWaters Flood Insurance Reform Act of $2012^{128}$ attempted to put the fund back on a responsible financial footing, but led to significant policy premium increases. ${ }^{129}$ The Homeowner Flood Insurance Affordability Act of $2014^{130}$ modified the 2012 act and responded to some of the premium cost issues. If the flood insurance subsidy was eliminated it would drop the value of properties susceptible to continued flooding. ${ }^{131}$

Related to the issues surrounding flood insurance is the identification of floodway and flood areas by the federal government. These areas must be examined more often and be more reflective of the effects of rising sea levels. ${ }^{132}$ Through the identification of such areas and their increasing size, the effects of flooding can be more clearly identified. ${ }^{133}$ The flooding data may then be utilized to identify impacts, building standards, flood insurance, and could lead to outright limitations on building within these areas.

There are other responses already in place, some with greater impact than others. There are numerous public and private institutions that are purchasing land for the purpose of protecting habitat, reinvigorating ecosystems, and other purposes. ${ }^{134}$ Cities and counties,

12642 U.S.C.A $\S$ 4001(a), (b) (West 2018).

127 Despite Hazard of Sea Level Rise, Senate Halts Flood Insurance Reforms, ThINKPROGRESS (Jan. 31, 2014, 3:37 PM), [hereinafter THINKPROGRESS], https://think progress.org/despite-hazard-of-sea-level-rise-senate-halts-flood-insurance-reforms-a39bfb $3 \mathrm{c} 21 \mathrm{ba} /$.

128 H.R. 4348, 112th Cong. (2012) (enacted).

129 THINKPROGRESS, supra note 127.

130 H.R. 3370, 113th Cong. (2014) (enacted).

131 See generally Joseph MacDougald \& Peter Kochenburger, Insurance and Climate Change, 47 J. MARSHALL L. REV. 101 (2013) (providing an overview of the insurance industry's response to climate change).

132 John Schwartz, James Glanz \& Andrew W. Lehren, Builders Said Their Homes Were Out of a Flood Zone. Then Harvey Came, N.Y. TIMES (Dec. 2, 2017), https://www .nytimes.com/2017/12/02/us/houston-flood-zone-hurricane-harvey.html.

133 Id.

134 See, e.g., PARTNER FOR CONSERVATION, https://partnershipforconservation.org/ (last visited Jan. 29, 2018). 
as a requirement of development, often dedicate land for public purposes as a condition of further development, though they are limited by the takings issue. ${ }^{135}$

A concept proposed by Ian McHarg, the Scottish landscape architect and author of Design with Nature, is transferable development credits. ${ }^{136}$ The concept is the transferring of the right to develop, in whole or in part, one area not desirable to develop to one that is desirable. ${ }^{137}$ In theory, it could result in little to no cost to the public for the reduction of private individual rights.

The Oregon Legislature adopted the concept of transferable development rights. ${ }^{138}$ However, to date, it has only been utilized in the inner city of Portland. ${ }^{139}$ The concept will need to be expanded in order to do more than simply provide urban density-for example, transferable development credits between rural and urban areas. Notwithstanding the potential for such approaches, development in any area is still dependent on the existence or provision of infrastructure such as roads, sewers, and water.

Conservation easements have been in use for some time. ${ }^{140}$ However, the purpose is to set aside land for maintaining open space for aesthetic purposes or other reasons. ${ }^{141}$ Conservation easements can also be successfully utilized to create buffers between existing waterways and the risk of high water and floods. ${ }^{142}$ Existing tax benefits for individuals may increase the use of easements establishing high water buffers. ${ }^{143}$ It may be more appropriate for public entities to purchase easements, such as New Jersey's rolling

135 See Dolan v. City of Tigard, 512 U.S. 374, 385, 114 S. Ct. 2309, 2316-17 (1994).

136 See generally IAN L. MCHARG, DESIGN WITH NATURE (1992).

137 Id.

138 OR. REV. STAT. ANN. § 94.531-.538 (2017).

139 See generally ECONOMIC \& PlanNing Systems, InC. \& OTAK, City of Portland Central City Density Bonus and Entitlement Transfer Mechanism Update (2015) https://www.portlandoregon.gov/bps/article/584504.

140 Private Lands Conservation: Conservation Easements, THE NATURE CONSERVANCY, https://www.nature.org/about-us/private-lands-conservation/conservationeasements/index.htm (last visited Jan. 30, 2018).

$141 \mathrm{Id}$.

142 Pennsylvania Land Trust Association, Riparian Buffer Protection via Local Government Regulation: A Guide and Model Ordinance for Pennsylvania Municipalities, CONSERVATIONTOOLS.ORG, https://conservationtools.org/guides/119-riparian-buffer-pro tection-via-local-government-regulation (last visited Mar. 28, 2018).

143 Id. 
easements, as a comprehensive response to increased high water and flooding.

Another potential tool for minimizing the effects of higher water could include new development standards, both for subdivisions and the modification of existing uses. The issue of "exactions" may need to be re-examined because responses to new development should take into consideration climate change issues along with current standards that deal with traffic congestion and control. ${ }^{144}$ New subdivision standards may include more attention to the impact of climate change by focusing on drainage, holding ponds, building standards, and similar changes. ${ }^{145}$ This will often include additional responsibility on homeowner associations for maintenance and upkeep of such facilities. It could also include greater requirements for the maintenance of green space, which can provide additional property to aid in the cooling of surrounding areas. ${ }^{146}$

The concept of "heat islands" must also be addressed as part of additional development standards.

The term 'heat island' describes built up areas that are hotter than nearby rural areas. The annual mean air temperature of a city with 1 million people or more can be $1.8-5.4^{\circ} \mathrm{F}\left(1-3^{\circ} \mathrm{C}\right)$ warmer than its surroundings. In the evening, the difference can be as high as $22^{\circ} \mathrm{F}$ $\left(12^{\circ} \mathrm{C}\right)$. Heat islands can affect communities by increasing summertime peak energy demand, air conditioning costs, air pollution and greenhouse gas emissions, heat-related illness and mortality, and water quality. ${ }^{147}$

\section{Strategies and Technologies}

As part of a property law response to climate change, certain development conditions may now become more accepted because they will be seen as an appropriate response to a recognized problem; for example:

- Trees and Vegetation-Increasing tree and vegetation cover lowers surface and air temperatures by providing shade and

144 John Schwartz et al., supra note 132.

145 See generally Sean F. Nolon, Bargaining for Development Post-Koontz: How the Supreme Court Invaded Local Government, 67 FLA. L. REV. 171 (2015) (explaining how land use boards can protect themselves and take advantage of the opportunities of negotiation).

146 Smart Growth and Heat Islands, U.S. ENVTL. Prot. AGENCY, https://www.epa.gov /heat-islands/smart-growth-and-heat-islands (last visited Apr. 9, 2018).

147 Heat Island Effect, U.S. ENVTL. PROT. AGENCY, https://www.epa.gov/heat-islands (last visited Apr. 9, 2018). 
cooling through evapotranspiration. Trees and vegetation can also reduce storm water runoff and protect against erosion. ${ }^{148}$

- Green Roofs-Growing a vegetative layer (e.g., plants, shrubs, grasses, trees) on a rooftop reduces temperatures of the roof surface and the surrounding air, and it also improves storm water management. Also called rooftop gardens or eco-roofs, green roofs achieve those benefits by providing shade and removing heat from the air through evapotranspiration. ${ }^{149}$

- Cool Roofs-Installing a cool roof (i.e., a roof made of materials or coatings that significantly reflect sunlight and heat away from a building) reduces roof temperatures, increases the comfort of occupants, and lowers energy demand. ${ }^{150}$

- Cool Pavements-Using paving materials that reflect more solar energy and enhance water evaporation than conventional pavements on sidewalks, parking lots, and streets not only cools the pavement surface and surrounding air, but can reduce storm water runoff and improve nighttime visibility. ${ }^{151}$

- Smart Growth-These practices cover a range of development and conservation strategies that help protect the natural environment while also making our communities more attractive, economically stronger, and more livable. ${ }^{152}$

\section{J. Property Rights Summary}

In considering the two extremes, public purchase of existing property rights either in the form of easements or fee simple, or simply doing nothing and allowing the steadily increasing coast line

148 Heat Islands-Using Trees and Vegetation to Reduce Heat Islands, U.S. ENVTL. PROT. AGENCY, https://www.epa.gov/heat-islands/using-trees-and-vegetation-reduce-heat -islands (last visited Apr. 9, 2018).

149 Region 8-Green Infrastructure: Low-Impact Development and Green Infrastructure in the Semi-Arid West, U.S. ENVTL. PROT. AGENCY, www.epa.gov/region8 /green-infrastructure (last visited Apr. 9, 2018).

150 Heat Islands-Using Cool Roofs to Reduce Heat Islands, U.S. ENVTL. PROT. AGENCY, www.epa.gov/heat-islands/using-cool-roofs-reduce-heat-islands (last visited Apr. 9, 2018).

151 Heat Islands-Using Cool Pavements to Reduce Heat Islands, U.S. ENVTL. PROT. AGENCY, www.epa.gov/heat-islands/using-cool-pavements-reduce-heat-islands (last visited Apr. 9, 2018).

152 Smart Growth-About Smart Growth, U.S. ENVTL. PROT. AGENCY, https://www.epa.gov/smartgrowth/about-smart-growth (last visited Apr. 9, 2018). 
and rivers to eliminate the improvements in their wake, it would appear that neither the cost nor the political stance can be sustained in today's environment absent a total change in the public's attitude toward climate change. Accordingly, a political middle ground will have to be found between public and private property rights that balances public and private rights in a manner understandable and acceptable to the public.

\section{II}

\section{RECommended Changes to STATEWIDE PlanNing GoALS AND RELATEd RULES AND POLICIES NECESSITATEd By ClimATE CHANGE}

In Part II.C, we look at changes to Oregon's land use policies, as mostly contained in Oregon's statewide planning goals and their implementing administrative rules needed to meet the challenges of climate change. Oregon has a unique planning and land use regulatory system, ${ }^{153}$ which is equipped to meet changing needs without repair to the legislature. ${ }^{154}$

Responses to climate change have three aspects: (1) mitigation, that is, how to reduce global warming gas emissions; (2) adaptation, that is, what is necessary to meet the impacts of climate change; and (3) sequestration or carbon capture and storage, that is, the need to reduce the amounts of greenhouse gasses in the atmosphere and oceans. ${ }^{155}$ Following a discussion of preliminary matters of general concern, this part identifies several changes needed in an update of Oregon's Statewide Planning Goals and rules in order to address each of the aspects of climate change. This Part also specifies some procedural changes to the processes surrounding the Goals, and finally it addresses whether the suggested changes and what else Oregon is doing, together, will be sufficient to meet Oregon's share of mitigation and sequestration.

The Oregon Legislature has identified global warming as a serious threat to Oregon in terms of reduced snowpack, loss of forests for

153 See generally Sullivan, supra note 12 (discussing Oregon's land use system).

154 OR. REV. STAT. ANN. § 197.005 (West 2018).

155 Elizabeth Grossman, Northwest Oyster Die-offs Show Ocean Acidification Has Arrived, YALEENVIRONMENT360 (Nov. 21, 2011), https://e360.yale.edu/features/north west_oyster_die-offs_show_ocean_acidification_has_arrived; Climate Change 2014 Synthesis Report, InTERgOvernMental PANEL ON Climate Change 71 (2014), http://ar5-syr.ipcc.ch/ipcc/ipcc/resources/pdf/IPCC_SynthesisReport.pdf. 
sequestration, and impacts on numerous industries. ${ }^{156}$ However, neither the Legislature, nor the Oregon Land Conservation and Development Commission (LCDC) with its department (DLCD), has attempted a comprehensive review of the state's land use system with climate change requirements as a central focus. Moreover, current land use policy does not require attention to climate change. ${ }^{157}$ Oregon's land use planning law does, however, contain a precatory guideline on the subject; "[t]he land use program should, but is not required to, help communities achieve sustainable development patterns and manage the effects of climate change." 158 Note the lack of requirements; the thrust of the guidance is on "effects," that is, on adaptation, but not on mitigation or sequestration.

Further, Oregon's LCDC has not reviewed or amended its Goals to address climate change, even though it has been formally petitioned to do so. ${ }^{159}$ Notwithstanding LCDC's refusal, other state agencies have acted. Based on the work of the United Nations' Intergovernmental Panel on Climate Change (IPCC) and the 2004 Oregon Governor's Advisory Group on Global Warming, ${ }^{160}$ the 2007 Oregon Legislature set a specific but non-binding objective: by 2050 , the mitigation of $\mathrm{CO}_{2} \mathrm{e}$ produced in Oregon will be $75 \%$ below 1990 levels. ${ }^{161}$ Even though that objective is non-binding, the Oregon Legislature, several state agencies, cities, counties, and private entities have developed programs aimed at accomplishing the result. ${ }^{162}$

Oregon's Global Warming Commission (OGWC) ${ }^{163}$ states that Oregon's emissions were 56.4 MM T (i.e., million metric tons) of

156 OR. REV. STAT. ANN. § 468A.200(4)-(6) (West 2018).

157 Id. $\S 197.010(2)(\mathrm{b})$.

158 Id.

159 Memorandum from Or. Dep't of Land Conservation and Dev. to Land Conservation and Dev. Comm'n (July 17, 2009). From this perspective, in reviewing the DLCD staff report in 2017 , it seems that the advantages of a new goal on climate change trump the disadvantages. Id. However, no new goal has been adopted yet. $I d$.

160 Or. DEP'T OF ENERGY, OREGON STRATEGY FOR GREENHOUSE GAS REDUCTIONS: GOVERNOR'S ADVISORY GROUP ON GLOBAL WARMING (2004), http://www.oregon.gov /energy/Data-and-Reports/Documents/2004\%20Oregon\%20Strategy\%20for\%20Green house $\% 20 \mathrm{Gas} \% 20$ Reductions\%20Report\%20Legislature.pdf.

161 OR. REV. STAT. ANN. § 468A.205(1)(c) (West 2018).

162 See Climate Action Plan, supra note 13; see also City OF PORTLAND, OR. \& Multnomah County, Climate ACtion Plan Progress RePort (2017), https://www portlandoregon.gov/bps/article/636700.

163 OR. ReV. STAT. ANN. § 468A.215 (West 2018) (creating the Global Warming Commission in 2007 to track and evaluate $\mathrm{CO}_{2} \mathrm{e}$ and its impact on Oregon through data and reports). 
CO2e in $1990 .^{164}$ Therefore, the 2050 target is 14.1 MMT. The most recent data indicates Oregon's emissions of $\mathrm{CO}_{2} \mathrm{e}$ are $63.4 \mathrm{MMT} .{ }^{165}$ Transportation is $37 \%$ of Oregon's greenhouse gas (GHG) emissions. ${ }^{166}$ Residential and commercial use represents $35 \%$ of Oregon's $\mathrm{CO}_{2} \mathrm{e}$ emissions, and if industrial sources are added, the built environment represents $55 \%$ of Oregon's CO2e. ${ }^{167}$

If one assumes that mitigation by 2050 must be proportionate by sector based on 1990 numbers, then the following table provides the facts as presented by OGWC: ${ }^{168}$

Table 1: Oregon Emissions by Sector, 1990-2015 (Million MT CO2e) $)^{169}$

\begin{tabular}{|l|c|c|c|c|c|c|c|c|c|c|}
\hline & 1990 & 1993 & 2000 & 2005 & 2010 & 2011 & 2012 & 2013 & 2014 & 2015 \\
\hline Transportation & 21.0 & 22.6 & 24.4 & 24.7 & 23.2 & 22.3 & 22.3 & 21.3 & 21.4 & 23.2 \\
\hline $\begin{array}{l}\text { Residential \& } \\
\text { Commercial }\end{array}$ & 16.6 & 19.9 & 23.1 & 22.0 & 23.3 & 22.5 & 20.8 & 22.0 & 21.4 & 22.2 \\
\hline Industrial & 13.9 & 16.9 & 18.0 & 13.7 & 12.3 & 12.2 & 11.5 & 11.9 & 12.4 & 12.8 \\
\hline Agriculture & 4.9 & 5.5 & 5.3 & 5.7 & 5.2 & 5.5 & 5.5 & 5.2 & 5.2 & 5.2 \\
\hline Total & 56.4 & 64.9 & 70.7 & 66.2 & 63.9 & 62.4 & 60.2 & 60.3 & 60.3 & 63.4 \\
\hline
\end{tabular}

The OGWC's 2017 report to the Legislature (the source of part of the above table), reports a high of $\mathrm{CO}_{2} \mathrm{e}$ in 2000 and a gradual decline through 2012 but then a spike back up in 2015, largely from the transportation sector. ${ }^{170}$

So far, the mean temperature on earth has risen $0.85^{\circ} \mathrm{C}$ since $1880 .{ }^{171}$ Once greenhouse gases enter the biosphere many remain there for hundreds of years and are cumulative. ${ }^{172}$ Huge amounts of $\mathrm{CO}_{2} \mathrm{e}$ have been stored in the land and its plants, in the oceans, or in

\footnotetext{
164 See infra Table 1.

165 See infra Table 1.

166 See infra Table 1.

167 See infra Table 1.

168 Biennial Report to the Legislature, supra note 14, at 18.

169 Id.

$170 I d$. at 14 . Likely a result of Oregon's coming out of the Great Recession, which hit the world in 2008 .

171 WORKING GROUP I CONTRIBUTION TO THE FIFTH ASSESSMENT REPORT OF THE Intergovernmental Panel on Climate Change, Climate Change 2013-The PhySICAL SCIENCE BASIS 5 (Thomas F. Stocker et al. eds., 2013) (discussing that "[t]he globally averaged combined land and ocean surface temperature data as calculated by a linear trend, show a warming of $0.85[0.65 \text { to } 1.06]^{\circ} \mathrm{C} 3$, over the period 1880 to 2012 ....").

172 See Working Group 1; The Scientific Basis, INTERGOVERNMENTAL PANEL ON Climate Change, https://www.ipcc.ch/ipccreports/tar/wg1/016.htm (last visited Feb. 1, 2018).
} 
atmospheric "sinks." Normally these sinks are in equilibrium in handling large amounts of inputs and outputs. Anthropocentric contributions are small but large enough to disturb the equilibrium. If the equilibrium is disturbed sufficiently, then tipping points occur, which the IPCC in 2014 expressed as a reason for concern. ${ }^{173}$ Several of the most well-known tipping points are from the snow and glacier melting in Greenland, Alaska, and the Antarctic, ${ }^{174}$ and as the oceans become warmer, of a $\mathrm{CO}_{2} \mathrm{e}$ gas, methane (about 20 times stronger than $\mathrm{CO}_{2}$ ), from methane hydrate crystals formed in cold water under high pressure in the lower parts of the oceans, including areas off the coast of Oregon. ${ }^{175}$

This review of Oregon's land use policies and Goals asks the reader to assume that there are inventories, studies and lists as required by each of the goals, and those requirements are not reiterated below. The reader may find the specific requirements of each goal by referring to the DLCD website which provides links to each of the Goals. ${ }^{176}$ Rather, the focus here is on what is to be done with the information required, that is, what are the implementation requirements that must be met by the affected local governments or state agencies? Examination of each of the goals reveals much about whether Oregon is doing enough, and soon enough to meet the $75 \%$ reduction over 1990 levels by 2050 goal.

Local governments have been taking independent action. For example, the City of Portland and Multnomah County, acting jointly, on April 10, 2017, committed to $100 \%$ renewable energy by $2050 .{ }^{177}$ In 2015, Portland and Multnomah County established a Climate

173 WORKING GROUP II CONTRIBUTION TO THE FIFTH ASSESSMENT REPORT OF THE InTERgOVERNMENTAL PANEl ON ClimATE CHANGe, Climate CHANGE 2014 - IMPACTS, ADAPTATION, AND VULNERABILITY SUMMARY FOR POLICYMAKERS 12 (Christopher B. Field et al. eds., 2014) (discussing that "[f]ive integrative reasons for concern (RFCs) provide a framework for summarizing key risks across sectors and regions").

174 Press Association, Antarctic Ice is Melting So Fast the Whole Continent May Be At Risk By 2100, The GUARDIAN (Oct. 12, 2015, 11:32), http://www.theguardian.com /environment/2015/oct/12/antarctic-ice-melting-so-fast-whole-continent-may-be-at-risk-by -2100 .

175 Ocean Chemistry-Climate Change Impacts on Methane Hydrates, WORLD OCEAN REV., http://worldoceanreview.com/en/wor-1/ocean-chemistry/climate-change-and-meth ane-hydrates/ (last visited Feb. 1, 2018).

176 See generally Goals, OR. DEP'T OF LAND CONSERVATION AND DEV., http://www .oregon.gov/LCD/Pages/goals.aspx\#Statewide_Planning_Goals (last visited Feb. 1, 2018).

177 Andrew Theen, Portland, Multnomah County Commit to Using 100\% Renewable Energy by 2050, OR. LIVE (Apr. 10, 2017, 4:00 PM), http://www.oregonlive.com/environ ment/index.ssf/2017/04/portland_multnomah_county_comm.html. 
Action Plan, which sets a goal of reducing local carbon emissions by $80 \%$ of 1990 levels by 2050 , with an interim goal of $40 \%$ by $2030 .{ }^{178}$ To meet these goals, residents will need to use $62 \%$ less electricity and drive 64\% fewer miles per day. ${ }^{179}$ Among the twenty objectives to be obtained by 2030 , the goals for buildings are to:

1. Reduce total energy use of all buildings built before 2010 by 25 percent. 2. Achieve zero-net carbon emissions for all new buildings and homes. 3. Supply 50 percent of all energy used in buildings from renewable resources, with 10 percent produced within Multnomah County from on-site renewable sources, such as solar. ${ }^{180}$

Beyond this preamble, this Part is divided into five sections: (a) land use goal and policy changes needed for mitigation; (b) land use policy and goal changes needed for adaptation; (c) land use policy and goal changes needed for sequestration; (d) procedural changes in Oregon's land use system needed to address climate change issues; and, finally (e) some considerations of whether Oregon is doing enough soon enough.

\section{A. Mitigation Potential for Land Use Goals and Climate Change: Transportation (Goal 12), Energy Conservation (Goal 13), and the Urban Growth Boundary (Goal 14)}

The work of Oregon's Global Warming Commission shows that $55 \%$ of Oregon's $\mathrm{CO}_{2} \mathrm{e}$ emissions come from housing, commercial, and industrial activities. ${ }^{181}$ To meet the $\mathrm{CO}_{2} \mathrm{e}$ emissions target of $75 \%$ reduction over 1990 levels by 2050, Oregon must reduce $\mathrm{CO}_{2} \mathrm{e}$ from residential, commercial, and industrial activity by 27.4 MMT below 2015 levels. ${ }^{182}$ It is safe to say that the bulk of these emissions are a product of urban activity and that a review of those planning goals related to urban uses should thus be the focus of any mitigation objective.

\footnotetext{
178 Climate Action Plan, supra note 13, at 7.

$179 \mathrm{Id}$. at 19.

$180 \mathrm{Id}$. at 26.

181 See supra Table 1.

182 Supra Table 1.
} 


\section{Mitigation Potential 1-Amend Goals to Reflect Ecodistricts and Climate Start Strategies}

The Goals Should Reflect the Need for Ecodistricts and Climate Smart Strategies for Reduction of $\mathrm{CO}_{2} \mathrm{e}$. Oregon's Urbanization policy as set forth in Statewide Planning Goal 14 requires "an orderly and efficient transition from rural to urban land use . . . [and] urban employment inside urban growth boundaries, to ensure efficient use of land, and to provide for livable communities." 183 In addition, "[u]rban growth boundaries shall be established and maintained by cities, counties and regional governments to provide land for urban development needs and to identify and separate urban and urbanizable land from rural land." 184

Based on a twenty-year prediction of need, communities must establish urban growth boundaries and the undeveloped but "urbanizable" land within those boundaries. ${ }^{185}$ Generally, urban services must not be extended outside urban growth boundaries. ${ }^{186}$ The boundaries can be expanded, but now only by compliance with multiple statutory and other standards. ${ }^{187}$ In addition, the Legislature has provided for planning for urban and rural reserves to deal with planning needs beyond the usual twenty-year planning horizon established by the statewide goals. ${ }^{188}$ The life of these reserves is to be not more than thirty years beyond the twenty-year urban growth area planning requirements. ${ }^{189}$

Goal 14 also calls for "livable communities." 190 It is possible to design neighborhoods to be net zero energy consumers ${ }^{191}$ by locating

\footnotetext{
183 OR. ADMIN. R. 660-015-0000(14) (2003).

184 Id.

185 Id.

186 See id.; OR. ADMIN. R. 660-015-0000(11) (2003); Foland v. Jackson Cty., 239 Or.App. 60, 70, 243 P.3d 830, 834 (2010); Dep't of Land Conservation and Dev. v. Fargo Interchange Serv. Dist., 27 Or. LUBA 150 (1994).

187 OR. REV. STAT. ANN. $\S \S 197.295-.314, .475-.490$ (West 2017); id. $\S \S$ 197A.300-.325 (West 2018).

188 See id. § 195.137 (West 20178) (defining "Rural reserve" and "Urban reserve").

189 Id. $\S \S 195.145(4), .141(2)(b)$. However, urban reserves can be for no less than ten years beyond the usual twenty-year planning time frame. OR. ADMIN. R. 660-021-0030(1).

190 OR. ADMIN. R. 660-015-0000(14) (2003).

191 See generally Earth Advantage Home Certification, EARTH ADVANTAGE, https://www.earthadvantage.org/certifications/earth-advantage-home-certification.html (last visited Feb. 1, 2018); Zero Energy Ready Home, OfFICE OF ENERGY EFFICIENCY \& RENEWABLE ENERGY, https://energy.gov/eere/buildings/zero-energy-ready-home (last visited Feb. 1, 2018) (providing an overview of certifications for zero energy homes).
} 
a combination of roads, pedestrian and bike paths, and essential services within walking distance. ${ }^{192}$ Further, building envelopes can be designed for energy efficiency and shared use of renewable energy resources to obtain the target, one version of which is called community solar. ${ }^{193}$ Community solar is well underway in several states, including Vermont. ${ }^{194}$ In short, communities with the above attributes are called EcoDistricts ${ }^{195}$ and should be integrated into Oregon's Statewide Planning Goals. For the whole of the Portland Metropolitan Area, Oregon's unique Metropolitan Service District is using its coordination and cooperation powers to marshal local government efforts through a Climate Smart Strategies program. ${ }^{196}$

\section{Mitigation Potential 2-Revise Goal 13}

Goal 13 should be revised to deal with emissions reductions related to energy production by providing emission reduction targets through the implementation of key programs, such as distributed generation and energy performance scores. In Oregon, enabling legislation authorizes cities to adopt solar access protection ordinances. ${ }^{197}$ Moreover, Oregon counties are mandated by State statute to allow, as outright uses, solar installations on residential and commercial structures. ${ }^{198}$

However, there are no specific requirements in the Statewide Planning Goals for protection and use of solar and wind at a personal or community scale. Statewide Planning Goal 13 on energy provides that "[1] and uses developed on the land shall be managed and

192 See, e.g., Geos Net Zero Energy Neighborhood-Arvada, CO, U.S.A., NAT'L RENEWABLE ENERGY LAB, https://www.asla.org/sustainablelandscapes/pdfs/GeosNeigh borhood_Fact_Sheet.pdf (last visited Mar. 16, 2018).

193 See Order Approving Oregon Public Utility Commission Staff's request to continue to advance Community Solar Implementation through AR 603 (Nov. 7, 2017), http://apps .puc.state.or.us/orders/2017ords/17-458.pdf (order memorialized the Nov. 7, 2017, on Nov. 8, 2017).

194 See Can't Have Panels at your House, Apartment or Business?, GREEN MOUNTAIN COMMUNITY SOLAR, http://gmsolar.us/ (last visited Feb. 1, 2018).

195 See Ethan Seltzer et al., Making EcoDistricts-Concepts \& Methods for Advancing Sustainability in Neighborhoods 8-9 (2010), https://ecodistricts.org/wp-content/uploads /2013/03/making_ecodistricts_concepts_and_methods_for_advancing_sustainability_in neighborhoods.pdf.

196 See generally City of Portland Metropolitan Region, Climate SMART STRATEGY FOR THE PORTLAND METROPOLITAN REgION (2014), https://www.oregon metro.gov/climate-smart-strategy.

197 OR. REV. STAT. ANN. § 227.190(1) (West 2018).

198 Id. § 215.439(1), (2). 
controlled to maximize the conservation of all forms of energy, based upon sound economic principles." 199 This goal has had no measurable effect on land use planning, as evidenced by the lack of implementation rules. In large part this is because other political and statutory authority has been used for energy planning and permitting purposes. Oregon's Department of Energy is responsible for providing the Legislature with a plan. ${ }^{200}$ Further examples of planning outside the Statewide Planning Goals, are: the Governor's 2012 draft ten year energy plan, ${ }^{201}$ the Seventh Power Plan of the Northwest Power and Conservation Council, ${ }^{202}$ the Oregon Public Utilities Commission's requirements for twenty-year Integrated Resource Plans from private gas and electric utilities ${ }^{203}$ which cover about $74 \%$ of Oregon's electricity and all of its natural gas customers, ${ }^{204}$ and the authority of the Oregon Energy Facility Siting Council. ${ }^{205}$ In addition, it is possible to determine how much mitigation will result from the implementation of EPA's now under fire Clean Power Plan ${ }^{206}$ in Oregon. According to EPA's Clean Power Plan, Oregon's power plants were targeted at $1026 \mathrm{lb} / \mathrm{MWh}$ of $\mathrm{CO}_{2}$ during the period from

199 OR. ADMIN. R. 660-015-0000(13).

200 OR. REV. STAT. ANN. § 469.060(1) repealed by Act, ch. 286, §1 Or. Laws (2017). "Every odd-numbered year, the State Department of Energy shall transmit to the Governor and the Legislative Assembly a comprehensive plan including comments on the energy forecasts of the utilities and on the department's independent analysis and evaluation." Id.

201 10-Year Energy Action Plan Modeling, THE CTR. FOR Climate STRATEGIES \& OR. DEP'T OF ENERGY (2012), http://www.oregon.gov/energy/energy-oregon/Documents/2012 $\% 20$ Energy\%20Action\%20Plan\%20Modeling\%20Report.pdf.

202 Seventh Northwest Conservation and Electric Power Plan, Nw. POWER AND CONSERVATION COUNCIL (2016), https://www.nwcouncil.org/energy/powerplan/7/plan/.

203 Public Utility Commission of Oregon, Integrated Resource Plans (IRPs), STATE OF OR., http://www.puc.state.or.us/Pages/electric_gas/Integrated-Resource-Plans.aspx (last visited Feb. 2, 2018).

204 Oregon Utility Statistics, OR. PUBliC UTILiTy COMM’N. 1 (2016), http://www.puc .state.or.us/docs/statbook2016WEB.pdf.

205 OR. REV. STAT. ANN. $§ 469.450$ (West 2018). Since 1997, Oregon's Energy Facility Siting Council has had a $\mathrm{CO}_{2}$ emissions standard gas fired generating units. The current standard is authorized by OR. REV. STAT. ANN. $§ 469.503$ and by rule for base load plants is now set at $0.675 \mathrm{lb} / \mathrm{kWh}$ limit on $\mathrm{CO}_{2}$ emissions. OR. ADMIN. R. 345-024-0550 (2003).

206 Order in Pending Case, W. Va. v. Envtl. Protection Agency, 136 S. Ct. 1000 (Feb. 9, 2016) (granting the stay of the Environmental Protection Agency's "Carbon Pollution Emission Guidelines for Existing Stationary Sources: Electric Utility Generating Units" by a 5-4 vote of the U.S. Supreme Court); see also Electric Utility Generating Units: Repealing the Clean Power Plan: Proposal, U.S. ENVTL. PRotection AgEnCY, PROTECTION AGENCY, https://www.epa.gov/stationary-sources-air-pollution/electric-util ity-generating-units-repealing-clean-power-plan-0 (last visited Feb. 1, 2018). 
2020 through 2029, and the EPA set the target for years past 2030 at $871 \mathrm{lb} / \mathrm{MWh}^{207}$

Of Oregon's eight in-state fossil fuel-based electrical generating units, Boardman is the only coal-based generating unit; and it is scheduled to close in $2020{ }^{208}$ The rest of the units are natural gas energy generation units (EGUs), five of which generate electricity consumed in Oregon. ${ }^{209}$ Legislation adopted in 2016 established a new Renewable Portfolio Standard for Oregon's utilities. ${ }^{210}$ Utility companies must now supply more than $50 \%$ of their energy from renewable sources by $2040 .{ }^{211}$ Furthermore, by 2030 they must eliminate coal-fired generation sources from their electricity delivery portfolio. ${ }^{212}$ Since 1997, Oregon's Energy Facility Siting Council has had a $\mathrm{CO}_{2}$ emissions standard; the current standard is authorized legislatively ${ }^{213}$ and by administrative rule, and is set at a 0.675 $\mathrm{lb} / \mathrm{kWh}$ limit for base load plant $\mathrm{CO}_{2}$ emissions. ${ }^{214}$

With regard to land use planning and Statewide Planning Energy Conservation Goal $13,{ }^{215}$ there are two choices for revision: either eliminate the goal because it has no impact, or craft an amendment that will cause land use decisions to be made based on minimizing fossil fuel-based energy use.

The argument for eliminating Goal 13 is based on a multitude of different mechanisms for planning. Given the activities of other state agencies, consideration should be given to replacing Goal 13 with a new Goal oriented around climate change. If Goal 13 is retained, it should be amended to include a longer time frame for energy

207 Clean Power Plan: State at a Glance, U.S. ENVTL. PROT. AGENCY (2015), https://ar chive.epa.gov/epa/sites/production/files/2016-09/documents/oregon.pdf.

208 Cassandra Profita, Why Oregon Imports Power from Fossil Fuels and Exports Renewable Energy, OR. PUBliC BROADCASTING (June 1, 2011), https://www.opb.org /news/blog/ecotrope/why-oregon-imports-power-from-fossil-fuels-and-exports-renewable -energy/; Ted Sickinger, A gassy future? Debate rages over what replaces PGE's Boardman coal plant, OR. LIVE (Jan. 21, 2017), http://www.oregonlive.com/business /index.ssf/2017/01/debate_heating_up_over_pges_re.html (discussing the controversy about closing down PGE's Boardman coal facility by 2020).

209 See How We Generate Electricity, PORTLAND GEN. ElECTRIC, https://www.port landgeneral.com/our-company/energy-strategy/how-we-generate-electricity (last visited Feb. 2, 2018).

210 OR. REV. STAT. ANN. § 469A.052(1) (West 2018).

211 Id. $\S 469$ A.052(1)(h).

212 S.B. 1547, 78th Leg. Assemb., Reg. Sess. (Or. 2016).

213 OR. REV. STAT. ANN. § 469.503 (West 2018).

214 OR. ADMIN. R. 345-024-5500 (2003).

215 Id. 660-015-0000(13) (2003). 
planning, at both local and state levels. It should also shift the sustainability guidelines into mandatory goal language. An alternative model is California's ongoing "smart growth" planning and sustainability efforts, which, although originally reflecting Oregon's efforts to follow "2007" (i.e., Cal. 2007 S.B. 375), ${ }^{216}$ have promoted cohesiveness in the relationship between subdivision and transportation planning.

Energy planning for the twenty-first century must consider both the climate change impacts of burning fossil fuels, as well as the national security ramifications of an interdependent grid that is highly vulnerable to disruption. Ecologically sound and healthy neighborhoods, as well as their planners, already have their sights set on transportation savvy, net zero energy, net zero water, and net zero waste "living buildings" in walkable neighborhoods supported by urban agriculture. A reorientation of Goal 13 to help Oregon meet these targets and outline ways to achieve them, would help regain Oregon's leadership in land use, sustainability, and climate change mitigation. But, if Hansen is right, time is of the essence. ${ }^{217}$

More specific requirements could be mandated through the Statewide Planning Goals in coordination with building code drafters' need to mandate energy performance matrices for new and existing buildings in order to provide the data for $\mathrm{CO}_{2} \mathrm{e}$ reductions. Energy performance scores for structures and communities will also help move the construction industry, both new and remodeling, toward producing net zero energy residential and commercial buildings and communities. ${ }^{218}$ These energy performance scores will provide a feedback loop for both local and state land use planning, by local and state governments, to determine progress toward meeting the 2050 goals.

\section{Mitigation Potential 3-Amend Goal 12}

Statewide Planning Goal 12 on Transportation should be amended to require measurable transportation $\mathrm{CO}_{2} \mathrm{e}$ reduction targets by jurisdiction, including reductions in vehicle miles traveled and accommodation of more diverse modes of transportation, such as

\footnotetext{
216 See S.B. 375, ch. 728, 2007-2008 Leg. Sess. (Cal. 2008).

217 See infra Part II.C.

218 See City of Portland, OR. Bureau of PlanNing AND Sustainability, ADMINISTRATIVE RULES: COMMERCIAL BUILDING ENERGY PERFORMANCE REPORTING 2 (2015), https://www.portlandoregon.gov/bps/article/542355.
} 
walking, biking and car-sharing. Statewide Planning Goal 12 deals with transportation. ${ }^{219}$ Ultimately Oregon must address the fact that $37 \%$ of Oregon's $\mathrm{CO}_{2}$ e gasses come from transportation, and that this sector has had the largest emissions increase of any sector in recent years. ${ }^{220}$ In its 2017 report to the Oregon Legislature, Oregon's Global Warming Commission stated that Oregon is in danger of not meeting its mitigation goals, largely as a result of $\mathrm{CO}_{2} \mathrm{e}$ emissions increases from 2014 to $2015,60 \%$ of which are attributable to transportation increases. ${ }^{221}$ Climate change questions with regard to transportation can be broken into 3 parts: (1) national (and California) performance standards for vehicles by manufacturer, for which the EPA has set the standard at 54.5 miles per gallon, fleet average, achievable by $2025 ;^{222}$ (2) changes in propulsion, i.e. hybrids, hydrogen and electric cars; and (3) changing and minimizing auto use, i.e. smart growth, autonomous cars, and integration of transit and land use planning.

Statewide Planning Goal 12 focuses on the mix of modes for most efficient transportation, requiring that transportation plans shall:

consider all modes of transportation including mass transit, air, water, pipeline, rail, highway, bicycle and pedestrian; (2) be based upon an inventory of local, regional and state transportation needs; (3) consider the differences in social consequences that would result from utilizing differing combinations of transportation modes; (4) avoid principal reliance upon any one mode of transportation; (5) minimize adverse social, economic and environmental impacts and costs; (6) conserve energy; (7) meet the needs of the transportation disadvantaged by improving transportation services; (8) facilitate the flow of goods and services so as to strengthen the local and regional economy; and (9) conform with local and regional comprehensive land use plans. Each plan shall include a provision for transportation as a key facility. ${ }^{223}$

Federal transportation planning with regard to reduction of $\mathrm{CO}_{2} \mathrm{e}$ can be divided into four parts:

219 OR. ADMIN. R. 660-015-0000(12) (2003).

220 Supra Table 1.

221 Biennial Report to the Legislature, supra note 14, at 16.

222 Regulations for Greenhouse Gas Emissions from Passenger Cars and Trucks, U.S. ENVTL. PROT. AGENCY, https://www.epa.gov/regulations-emissions-vehicles-and-engines /regulations-greenhouse-gas-emissions-passenger-cars-and (last visited Apr. 9, 2018). However, in March of 2017, U.S. President Donald Trump has proposed rolling back the CAFÉ standards. Paul A. Eisenstein, Trump Rolls Back Obama-Era Fuel Economy Standards, NBC NEws (Mar. 16, 2017, 7:10 AM), http://www.nbcnews.com/business /autos/trump-rolls-back-obama-era-fuel-economy-standards-n734256.

223 OR. ADMIN. R. 660-015-0000(12). 
- Improving fuel economy (the Corporate Average Fuel Economy [CAFÉ] target is 54.5 miles per gallon by 2025)

- Reducing the carbon content of fuels use (i.e., clean fuels and electric vehicles)

- Reducing the amount of driving (that is, vehicles miles traveled) by means of better land use and pricing

- "Improv[ing] operational efficiency of transportation

The federal government's 2015 transportation act as implemented anticipated $\$ 11.6$ billion for community planning and development block grants for the 2018 fiscal year. ${ }^{225}$ As the transportation system changes, laws will need to be modernized in order to accommodate driverless cars.

Oregon's Department of Transportation developed a 2012 Climate Change Adaptation Strategy Report that focuses on interconnectivity, managing uncertainty and flexibility, linking adaptation and mitigation, and integrating adaptation into its practices and programs. $^{226}$

ODOT was charged by statute with developing a Statewide Transportation Strategy (STS) for achieving the greenhouse gas emissions reduction goals 227 of a $75 \%$ reduction in $\mathrm{CO} 2 \mathrm{e}$ gasses below 1990 levels by 2050. The 2013 STS is based on eighteen different strategies and full implementation of all of them would result in a future with $60 \%$ fewer GHG emissions than present in $1990 .{ }^{228}$ The three "efficient land use" strategies of the STS are:

224 U.S. DeP'T OF TransP., Module 11: Sustainable Transportation, InTELLIGENT Transp. Sys. Joint Program OfFice Research and InNOVAtive TeCH. Admin. 17 (2013), https://www.pcb.its.dot.gov/eprimer/documents/module11p.pdf.

22523 U.S.C.A. § 133(b)(1) (West 2017); see Memorandum from Walker C. Waidelich, Jr., Associate Administrator for Infrastructure, Federal Highway Administration, to Division Administrators, Directors of Field Services, Federal Highway Administration (Mar. 7, 2016), https://www.fhwa.dot.gov/specialfunding/stp/160307.cfm.

226 OR. DEP'T OF TRANSP., ODOT'S CLIMATE CHANGE ADAPTION STRATEGY REPORT 4-5 (2012), http://www.oregon.gov/ODOT/Programs/TDD\%20Documents/Climate -Change-Adaptation-Strategy.pdf.

227 OR. ReV. StAT. ANN. § 184.889(1) (West 2018) (repealed by H.B. 2017-A, 78th Or. Leg. Assemb., Reg. Sess. (Or. 2017)).

228 Or. DeP'T of Transp., Oregon Statewide Transportation Strategy: A 2050 VISION FOR GREENHOUSE GAS EMISSIONS REDUCTION 45 (2013), http://www .oregon.gov/ODOT/Planning/Documents/Oregon_Statewide_Transportation_Strategy.pdf. 
Strategy 13-Compact, Mixed-Use Development

Promote compact, mixed-use development to reduce travel distances, facilitate use of zero- or low-energy modes (e.g., bicycling and walking) and transit, and enhance transportation options.

\section{Strategy 14-Urban Growth Boundaries}

Create full-service healthy urban areas to accommodate most expected population growth within existing Urban Growth Boundaries (UGB) through infill and redevelopment. [And]

\section{Strategy 15-More Efficient Industrial Land Uses}

Encourage and incentivize more efficient use of industrial land through closer proximity of shippers and receivers, consolidated distribution centers, and better access to lowcarbon freight modes. ${ }^{229}$

Oregon's 2017 transportation strategy ${ }^{230}$ takes significant strides toward climate mitigation and adaptation. It firmly commits Oregon transportation planning to Oregon's $\mathrm{CO}_{2} \mathrm{e} 2050$ goal of achieving a $75 \%$ reduction in emissions below 1990 levels. ${ }^{231}$ It establishes a mechanism for evaluating Oregon's clean fuels program. ${ }^{232}$ It establishes a program for helping moderate-income households retire high-polluting older vehicles. ${ }^{233}$ It takes initial steps to reduce pollution from cars stuck in traffic jams by establishing congestion pricing for use of Oregon' highways. ${ }^{234}$ It requires establishment of a rebate program to purchasers of zero-emission and electric vehicles. ${ }^{235}$ It establishes a Mega Transportation Projects Task Force to study how Oregon selects and approves projects costing at least $\$ 360$ million, such as the Columbia River Crossing between Portland, Oregon and Vancouver, Washington. ${ }^{236}$ Lastly, it commences programs for integration of hybrid, electric, and autonomous vehicles into Oregon's transportation planning. ${ }^{237}$

229 Id. at $84-87$.

230 H.B. 2017-A, 78th Or. Leg. Assemb., Reg. Sess. (Or. 2017).

231 Or. REV. STAT. ANN. § 468A.205(1)(c) (West 2018) (amending OR. REV. STAT. ANN. § 184.617(1)(j) (West 2018)).

232 H.B. 2017-A § 160(b) 78th Or. Leg. Assemb., Reg. Sess. (amending OR. REV. STAT. 468A.275).

$233 I d . \S 150(2)$.

234 Id. $\S 120(3)$.

235 Id. $\S \S 148-49$.

236 Id. § 121(1).

237 Id. § 75; OR. REV. STAT. ANN. § 803.420(9) (West 2018). 
There are specific rules setting forth mitigation requirements for the Portland area, Oregon's biggest population center. Metro (the Portland Metropolitan Planning Organization) was required to and did amend its regional framework plan and the regional growth concept to select and incorporate a preferred land use and transportation scenario to meet a $35 \%$ reduction over 2005 emission levels in per capita greenhouse gas emissions by $2050 .^{238}$ While the forgoing performance measures are required, there are no required specific evaluation criteria. ${ }^{239}$ Other metropolitan areas in Oregon have a $30 \%$ target over 2005 emissions levels. However, these other metropolitan areas are not required to engage in the rigorous planning required for the Portland Metropolitan area. It appears somewhat strange to use 2005 levels as benchmarks, when the State's reduction goal is based on $1990 \mathrm{CO}_{2}$ e levels. ${ }^{240}$ The functional plans to implement the global warming gas reduction targets for Metro are subject to review by Oregon's Land Conservation and Development Commission. ${ }^{241}$

As the transportation system changes in response to the impacts of $\mathrm{CO}_{2} \mathrm{e}$ increases, Statewide Planning Goal 12 needs to be modernized in order to accommodate driverless cars and trucks. The land use impacts of changing highway use and funding patterns must be identified and addressed. Per capita emissions standards will need to be modified to accommodate more bicycle use, such as Portland's new rent-a bike program. New subdivision plans need to require walking and biking paths, as well as the requisite rights-of-way both for bikes and walkers. As congestion pricing through tolls is implemented, ${ }^{242}$ land use in the areas affected must be changed to accommodate alternative commuting choices. These changes impose the need for significant changes to Goal 12 and its implementing rules.

238 OR. ADMIN. R. 660-044-0020(3) (2003).

239 See id. 660-044-0040(5)(b) (2003).

240 See OR. REV. StAT. ANN. § 468A.205 (West 2018).

241 OR. ADMIN. R. 660-044-0060(3) (2003).

242 Several examples exist to show that once price is tied directly to access and use, the demand for additional lanes is reduced. They include a new bridge across the Mississippi in St. Louis and the floating bridge crossing Lake Washington in Seattle. See, e.g., Zhan Guo et al., Are Land Use Planning and Congestion Pricing Mutually Supportive?, 77 J. AM. PLAN. ASSOC. 232 (2011). 


\section{Mitigation Potential 4-Amend Goal 14}

Goal 14, dealing with the Urban Growth Boundary, should be amended to account for climate refugees and changes in the nature of housing stocks. Statewide Planning Goal 14 addressing Urban Growth Boundaries ${ }^{243}$ provides that: "Urban growth boundaries shall be established and maintained by cities, counties and regional governments to provide land for urban development needs and to identify and separate urban and urbanizable land from rural land."244 A current urban growth boundary goal must consider: (1) the growth expected from climate refugees migrating to Oregon; ${ }^{245}$ (2) $\mathrm{CO}_{2} \mathrm{e}$ increases resulting from urbanizing any additional area to the urban growth boundary; ${ }^{246}$ (3) the $\mathrm{CO}_{2} \mathrm{e}$ impacts of meeting other planning requirements, such as a twenty-year land supply for housing and industry, and a fifty year period for urban and rural reserves; ${ }^{247}$ and (4) measures necessary to reduce the aggregate of these factors in order to meet Oregon's 2050 goal of reaching GHG levels that are $75 \%$ below 1990 levels. $^{248}$ This revision of Goal 12 anticipates climate refugees beyond the mere twenty-year supply of land. The revision also anticipates a shift in housing stock to meet the needs of these refugees. In addition, an urban growth boundary goal that is responsive to climate change would assure that any increase in greenhouse gases are met with sufficient sequestration efforts as the boundary addition is urbanized.

243 OR. ADMIN. R. 660-015-0000(14) (2003).

244 Id.

245 See generally Environmental Migrants and the Future of the Willamette Valley: A Preliminary Exploration, PORTLAND STATE UNIV. (2011), https://www.pdx.edu/usp/sites /www.pdx.edu.usp/files/Environmental_Migrants.pdf (discussing the level of preparedness to accommodate new population growth due to climate migration in Oregon's Willamette Valley).

246 Climate change mitigation is not a required consideration in adding land to an Oregon urban growth boundary, but adaptation requirements are addressed by excluding land that "is subject to significant development hazards, including a risk of landslides, a risk of flooding because the land is within the 100-year floodplain or is subject to inundation during storm surges or tsunamis, and other risks determined by the commission.” OR. REV. STAT. ANN. § 197A.320(2)(b)(B) (West 2018).

247 Id. § 195.145(4) (West 2018); id. § 197.626 (West 2018).

$248 I d . \S$ 468A.205(1)(c) (West 2018). 


\section{B. Adaptation Potential for Land Use Goals and Climate Change: Air, Water, and Land Use (Goal 6); Hazards (Goal 7), the Willamette River (Goal 15); Estuaries (Goal 16); Coastal Shorelands (Goal 17); Beaches and Dunes (Goal 18); and Ocean Resources (Goal 19)}

The idea of adaptation is based on the fact that climate change emissions mitigation and sequestration will not be sufficient to prevent significant climate change. Some greenhouse emissions stay in the atmosphere and in waters for many years: these elements serve as "sinks" for these gasses to accumulate. ${ }^{249}$ Further, such sinks are ubiquitous; that is, emissions in Oregon will find their way into and increase the quantities in one of several sinks, such as the atmosphere and the oceans. Increases in temperature, sea level rise, effects on species, and other impacts require local adaptation in order to minimize human, property, animal and plant losses. Several of Oregon's Statewide Planning goals require adjustments to counter the impacts of Climate Change.

\section{Adaptation Potential 1-Amend Goal 6}

Goal 6 should be amended by reconciling requirements of other agencies and adding climate adaptation mechanisms dealing with air, water and land use, including the designation of areas likely to be susceptible to forest fires, and amend the Goal's concept of carrying capacity to integrate tipping points into Oregon's land use process. Oregon Statewide Planning Goal 6 requires that discharges from new development, when added to those of existing development, shall not exceed the "carrying capacity" of air or water resources. ${ }^{250} \mathrm{~A}$ manifestation of carrying capacity is the existence of tipping points. The 2017 Fourth National Climate Assessment contains the following:

Of particular concern is the potential for coastal ecosystems to cross thresholds of rapid change ("tipping points"), beyond which they exist in a dramatically altered state or are lost entirely from the area; in some cases, these changes will be irreversible. These unique, "no-analog" environments present serious challenges to resource managers, who are confronted with conditions never seen before. The ecosystems most susceptible to crossing such tipping points are

249 See infra Part II.C.

250 Or. Admin. R. 660-015-0000(6) (2003); Oregon's Statewide Planning Goals \& Guidelines Goal 6: Air, Water and Land Resources Quality, OREGON.GOV, http://www.oregon.gov/LCD/docs/goals/goal6.pdf. 
those that have already lost some of their resilience due to degradation or depletion by non-climatic stressors. Certain coastal ecosystems are already rapidly changing as a result of interactions between climatic and non-climatic factors, and others have already crossed tipping points. Eelgrass in the Chesapeake Bay died out almost completely during the record-hot summer of 2005, when temperatures exceeded the species' tolerance threshold of $86^{\circ} \mathrm{F}$, and subsequent recovery has been poor. Severe low-oxygen events have emerged as a new phenomenon in the Pacific Northwest due to changes in the timing and duration of coastal upwelling. These have led to high mortality of Dungeness crabs and the temporary disappearance of rockfish, with consequences for local fisheries. Reducing non-climatic stressors at the local scale can potentially prevent crossing some of these tipping points. ${ }^{251}$

As this discussion shows, scientists are now recognizing that there may be tipping points beyond which it will be impossible for the biosphere to right itself. What better definition of carrying capacity could there be? Goal 6 should be modified and a DLCD rule implementing the "carrying capacity" language of Goal 6 with climate change as the focus should be adopted. In the interim, land use lawyers and climate change advocates need to consider how to get local governments to consider climate change when considering comprehensive plan and urban growth boundary changes.

The United States Environmental Protection Agency (EPA) implements the Clean Air Act, the Clean Water Act, the Resource Conservation and Recovery Act (RCRA), and the Comprehensive Environmental Response, Compensation and Liability Act (CERCLA), among others. Oregon's Department of Environmental Quality (DEQ) is delegated authority over many provisions provided for within these federal acts. ${ }^{252}$ In addition, the National Marine Fisheries Service has used the Endangered Species Act (ESA) to undertake extensive regulation of land and wetland areas for habitat protection through its endangered and threatened fish consultation process and the issuance of biological opinions. ${ }^{253}$ Within the Oregon

251 Coastal Zone Development and Ecosystems, U.S. GlobAl CHANGE RESEARCH PROGRAM, (citations omitted), http://nca2014.globalchange.gov/report/regions/coasts \#narrative-page-16840 (last visited Mar. 28, 2018).

252 See, e.g., National Pollutant Discharge Elimination System: Memorandum of Agreement, U.S. ENVTL. PROT. AGENCY (2013), https://www.epa.gov/sites/production /files/2013-09/documents/or-moa-npdes.pdf.

253 See, e.g., Letter from William W. Stelle, Jr., Regional Administrator, NOAA, to Shawn Zinszer, Chief, Reg. Branch, U.S. Army Corps of Engineers and Joyce Casey, Chief, Enviro. Resources Branch, Planning, Programs and Project Mgmt. Division, U.S. 
state land use framework, DLCD and agencies such as DEQ are charged with coordination under state law. ${ }^{254}$ Generally, state agencies are charged with acting in compliance with the Statewide Planning Goals and implementing rules, as well as acting compatibly with acknowledged comprehensive plans. ${ }^{255}$ However, forest operations under Oregon's Forest Practices Act are exempt. ${ }^{256}$ Other state agency decisions may avoid complying with the goals and plans if acting under an express mandate, in a manner consist with the goals, but where an agency plan or program cannot be achieved by acting compatibly with the local plan, and the agency has followed its certified coordination program. ${ }^{257}$ To the extent DEQ retains permit authority, coordination takes place through a signoff at the time of application by DLCD through a Land Use Coordination System (LUCS) ${ }^{258}$ Oregon DEQ operates under a delegation of power from EPA and issues operating permits for air emissions from power plants. ${ }^{259}$ DEQ has no control over forest fires, although the fires in Oregon and California in 2017 are indicators of what is to come from climate change. ${ }^{260}$

\section{Adaptation Potential 2-Amend Goal 7}

Goal 7 should be amended to reflect the current multi-jurisdictional hazardous management plans now required under federal law and change the local government notice provision, ORS 197.047, to assure proper planning for climate change adaptation in local jurisdictions, including providing an enforceable declaration of managed retreat after a first major event, rolling easements, and reclamation of diking district areas for estuarine and river biota productivity.

\footnotetext{
Army Corps of Engineers (Mar. 14, 2014), http://www.nwp.usace.army.mil/Portals/24 /docs/environment/SLOPES-IV/14Mar14_SLOPES-V-Transport.pdf. Fed. Reg, 111,39630 (June 10, 2002) (discussing the U.S. EPA's delegation of authority for Title V permitting to Oregon's Department of Environmental Quality); PGE Boardman, OR. DEP'T. OF ENV. QuALITY, http://www.oregon.gov/deq/Programs/Pages /PGE-Boardman.aspx (last visited Apr. 9, 2018).

260 Kathie Dello, Prepare for Larger Longer Wildfires, NATURE (Oct. 13, 2017), https://www.nature.com/news /prepare-for-larger-longer-wildfires-1.228.
} 
Adaptation planning for natural hazards in Oregon is currently handled under Statewide Planning Goal 7.61 This planning goal requires local governments to reduce risks to life and property in areas prone to natural hazards. Areas prone to natural disasters and hazards are those areas subject to floods, landslides, earthquakes, and other hazards unique to specific localities or regions, that are known to result in death or endanger the works of man. The below Appendix to this Article provides a map of Oregon's hazard areas. DLCD is required to review information and inventories provided by the state and federal governments to determine whether to notify local governments ${ }^{262}$ that a response is required. ${ }^{263}$ Local governments are required to respond within thirty-six months of this notice and to perform an assessment based on new inventory information. ${ }^{264}$ This assessment includes: (1) hazard frequency, severity and location; (2) effects on existing and future development; (3) possible development in hazard areas that will increase severity and frequency; and (4) land uses to be allowed in the identified hazard areas. ${ }^{265}$ "Developments subject to damage or that could result in loss of life shall not be planned nor located in known areas of natural disasters and hazards without appropriate safeguards." 266

Goal 7 was updated in 2002. ${ }^{267}$ Oregon's Natural Hazard Management Program was last updated in 2012, and includes fiftyfour pages of action items. ${ }^{268}$ While the Natural Hazard Management Program focuses heavily on wildfires, flooding, and subduction earthquake effects, it contains no direct mention or analysis of climate change impacts.

A critical question that needs to be answered by state and local governments is which items of infrastructure need to be moved and which need to be protected from the inevitable wave surges and other and environmental impacts that will occur due to climate change. At

261 Or. Admin. R. 660-015-0000(7)(2003), http://www.oregon.gov/LCD/docs/goals /goal7.pdf.

262 OR. Rev. StAT. AnN. § 197.047 (West 2018); Keicher v. Clackamas Cty., 175 Or. App. 633, 29 P.3d 1155 (Or. Ct. App. 2001).

263 OR. ADMIN. R. 660-015-0000(7).

264 Id.

$265 I d$.

$266 I d$.

267 Id.

268 See Or. PARTNERShIP FOR Disaster Resilience, State of OREgOn NATURAL HAZARDS MitigATION PLAN (2012), http://www.oregon.gov/lcd/haz/pages/nhmp.aspx\# Oregon_Natural_Hazards_Mitigation_Plan. 
this point, the plans do not address the difficult legal and voter concerns involved in that question. James Hansen says:

The important point is that the uncertainty is not about whether continued rapid $\mathrm{CO} 2$ emissions would cause large sea level rise, submerging global coastlines - it is about how soon the large changes would begin. The carbon from fossil fuel burning will remain in and affect the climate system for many millennia, ensuring that over time sea level rise of many meters will occurtens of meters if most of the fossil fuels are burned. That order of sea level rise would result in the loss of hundreds of historical coastal cities worldwide with incalculable economic consequences, create hundreds of millions of global warming refugees from highly-populated low-lying areas, and thus likely cause major international conflicts. ${ }^{269}$

Because of the on-going nature of storm surges and rising sea levels, climate change adaptation in Oregon-through legislation, changes in the Goals, and modifications of the hazard plans as funded by FEMA - should require that urban jurisdictions not simply replace what has been damaged by initial storm events, but also use the planning process to determine which areas will be rebuilt and which will not, based on likelihood of recurrence, safety and cost. A planning exercise was undertaken by DLCD, which resulted in a 2009 publication, Climate Ready Communities, but it contains no time frames, or mandates or money. ${ }^{270}$

While Oregon's state and coastal planning processes inadequately address projected climate change trends, there is outside pressure, and some money available, to assist with coastal hazard planning. ${ }^{271}$ Communities that develop and adopt local natural hazard mitigation plans are eligible for mitigation grant funding and meet requirements of the goal to reduce risk to people and property from floods, wildfires, earthquakes, tsunamis, and coastal erosion. ${ }^{272}$ Oregon coastal counties have adopted such plans and are currently completing the first updates. These plans list detailed information on perceived hazards such as flooding and general adaptation goals. However, neither Goal 7 nor the plans currently address climate change

269 Hansen et al., Assessing "Dangerous Climate Change": Required Reduction of Carbon Emissions to Protect Young People, Future Generations and More, 8 PLOS ONE 6 (Dec. 3, 2013).

270 See generally Climate READY COMMUNITIES, supra note 32.

271 See OR. DEP'T OF LAND CONSERVATION \& DEV, GRANTS, http://www.oregon.gov /LCD/Pages/grants.aspx (last visited Nov. 12, 2017).

272 OR. ADMIN. R. 660-015-000(7) (2003). 
adaptation specifically. In particular, they do not address "managed retreat," in which portions of public infrastructure, such as pipes and roads, must be abandoned or moved elsewhere in case of inundation from a major storm wave or tsunami or sea level rise and storm surges.

In hazard planning, the dominant agency is not the DLCD but the Federal Emergency Management Agency (FEMA). If a home is within the hundred-year floodplain of any body of water, its purchaser will not be able to obtain a loan backed by a federal mortgage agency (e.g., FHA, Fannie Mae or Freddie Mac) unless that person has flood insurance. ${ }^{273}$ Flood insurance is not available unless the local governmental entity has an acceptable zoning code, which regulates construction in floodplains. ${ }^{274}$ The areas covered are shown on Flood Insurance Rate Maps (FIRMs). With impetus from past giant storms such as Hurricanes Katrina, which impacted New Orleans, Sandy, and more recently Harvey and Irma, ${ }^{275}$ FIRMs are now accounting for risks of significant storms throughout the United States. ${ }^{276}$ Working with the Oregon Department of Geology and Mineral Industries (DOGAMI), FEMA is revising FIRMs covering the Oregon Coast and is establishing new lines for various types of flooding, specifically storm surge or velocity flooding (i.e., VE zones). ${ }^{277} \mathrm{In}$ addition, beginning in March of 2016, in order for state and local governments to be eligible for pre-disaster mitigation planning moneys, those with Hazard Mitigation Plans will be required to address the costs associated with projected climate change impacts. ${ }^{278}$

273 See, e.g., Flood Insurance Requirements for Mortgage Loans Secured by a One to Four-Unit Property, FANNIE MAE, (Mar. 14, 2018), https://www.fanniemae.com/content /guide/servicing/b/3/02.html.

27444 C.F.R.CFR $§ 59.2($ b) (2018).

275 For example, at the end of 2016 FEMA released preliminary FIRMs for Tillamook County. See Tillamook COUNTY, Multi-JurisDictional NATURAL HazARDS MitigATION PLAN 161 (2017), http://www.co.tillamook.or.us/gov/ComDev/NHMP/Plan Files/FULL9_7_17.pdf. For the situation in Florida, see Casey Logan, Hurricane Irma Aftermath: Floridians Without Flood Insurance Face Astronomical Bills, News-Press, (Sept. 19, 2017, 1:57 PM), http://www.news-press.com/story/news/2017/09/19/floridians -without-flood-insurance-face-big-bills-questions/678379001/.

276 See TILLAMOOK CTY., FLOODS, http://www.co.tillamook.or.us/Gov/ComDev/NH MP/SeptemberMeeting/8_Risk_Assessment_Chapter_Example_(without_addenda).pdf (last visited Nov. 12, 2017).

277 Zone V, FEMA, https://www.fema.gov/zone-v (last visited Apr. 8, 2018).

278 FEMA, State Mitigation Plan Review Guide 15 (FP 302-094-2, 2015), https://www.fema.gov/media-library/assets/documents/101659. (FEMA will require local governments with hazard plans (to determine) the "probability of future hazard events" in 
Since the National Flood Insurance Act (NFIA) requires FEMA to review flood maps at least once every five years to assess the need for updating all floodplain areas and flood risk zones, ${ }^{279}$ agency activity is clearly ongoing, and is therefore subject to the ESA's consultation requirements. ${ }^{280}$ Flooding and storm surges are major concerns along the Oregon coast. Federal law, particularly the flood insurance system managed by FEMA, encourages development and re-building in highrisk areas. ${ }^{281}$ Under current federal law, homeowners can insure their homes against flooding for up to $\$ 250,000$, and the homes' contents for up to $\$ 100,000 .^{282}$ Renters can cover their belongings for up to $\$ 100,000{ }^{283}$ Nonresidential property owners can insure a building and its contents for up to $\$ 500,000$ each. $^{284}$ The average flood insurance premium for a homeowner is about $\$ 700$ a year. ${ }^{285}$ However, in a designated oceanfront velocity storm zone, ${ }^{286}$ the annual coverage premium in Oregon for a $\$ 250,000$ home with $\$ 100,000$ contents is approximately $\$ 8142.79 .{ }^{287}$ As a result of federal legislation passed in 2012 , even as modified by affordability legislation passed in 2014 , the

state mitigation plans and "considerations of changing future conditions, including the effects of long-term changes in weather patterns and climate on the identified hazards." See Element S4.); see also FEMA, Hazard Mitigation Planning Frequently Asked Questions: How Will FEMA Determine If A State Addressed Climate Change?, https://www.fema.gov/hazard-mitigation-planning-frequently-asked-questions (last visited Mar. 2, 2018).

27942 U.S.C. $\S \S 4101(\mathrm{e}),(\mathrm{f})(1)$ (2012).

280 See Nat'l Wildlife Fed'n v. FEMA, 345 F. Supp. 2d 1151, 1172-73 (W.D. Wash. 2004).

281 See Logan, supra note 275.

282 Available Flood Coverage, FEMA, https://www.fema.gov/faq-details/Available -Flood-Coverage/. These numbers may change as Congress must pass new legislation by March 23, 2018. See National Flood Insurance Program: Reauthorization, FEMA, https://www.fema.gov/national-flood-insurance-program/national-flood-insurance-pro gram-reauthorization-guidance (last visited Mar. 2, 2018).

283 Id.

284 Id.

285 Kimberly Lankford, How Much does Flood Insurance Cost, KIPLINGER (June 1, 2015), https://www.kiplinger.com/article/insurance/T028-C001-S003-how-much-flood-in surance-costs.html.

286 There are two velocity zones: the V zone line or elevation is established based on interpolations and the VE zone is established on the basis of detailed information on base flood elevation. See ZONE CLASSIFICATIONS, http://www.floodmaps.com/zones.htm (last visited Apr. 8, 2018).

287 The Flood Insurance Agency, Positively Elevated VE and V1-30 Zones, PRIVATE CLIENT FLOOD, http://www.privatefloodselect.com/oregon (last visited Mar. 2, 2018). 
cost of flood insurance will go up even more for properties where repetitive flood damage occurs, and for vacation homes. ${ }^{288}$

Repetitive claims are a major problem. In Oregon, the various county Multi-Jurisdictional Natural Hazards Mitigation Plans exposed the number of repetitive claims. For example, according to the 2017 Tillamook Plan, within the County there are 2279 flood insurance policies in force with 623 loss payments and 61 repetitive losses. ${ }^{289}$ FEMA has a program that provides funds for planning as well as limited funds to acquire habitat for endangered properties, ${ }^{290}$ but the program has not been well funded and is subject to abuse. ${ }^{291}$

Climate change will cause more frequent storm surge waves, while the anticipated tsunami following a Cascadia Subduction Earthquake is likely to occur only once within any reasonable planning horizon. State and local governments can receive federal assistance through the Stafford Act as amended. ${ }^{292}$ Under the Stafford Act, upon request of a governor and a declaration of a disaster by the President, state and local governments are eligible to receive up to ninety percent of the funding needed to rebuild a facility in a different location, so long as authorities determine that the facility should not be repaired or replaced. While it is easy to see how this law might apply in a tsunami inundation zone, it is more difficult to see from the plans available how local governments might apply the law in the wake of less severe scenarios, for example, a storm wave on a spring tide with a significant southwest wind and a one-foot sea level rise. In other words, the current framework does not provide clear guidance on how

288 Eric Lipton et al., Flood Insurance, Already Fragile, Faces New Stress, N.Y. TIMES (Nov. 12, 2012), http://www.nytimes.com/2012/11/13/nyregion/federal-flood-insurance -program-faces-new-stress.html?pagewanted $=$ all\&_r $=0$ \&pagewanted $=$ print.

289 TILLAMOOK CTY., supra note 276, at 174-76, tbls.44, 45 \& 46.

290 See Hazard Mitigation Grant Program, FEMA, https://www.fema.gov/hazard-miti gation-grant-program (last visited Mar. 2, 2018); SURVEY OF HAZARD MiTIGATION Planning, OfF. OF InsPector General, DeP'T of Homeland SeCurity 7 (Aug. 2012), http://www.oig.dhs.gov/assets/Mgmt/2012/OIG_12-109_Aug12.pdf.

291 "Mitigation officials also said that the amount of funding available from the Predisaster Mitigation program is limited and often earmarked by Congress for specific projects. The Pre-disaster Mitigation Directorate was appropriated \$114 million in FY 2008 and $\$ 90$ million in 2009 , and earmarks accounted for a total of $37.4 \%$ of these funds." FEMA's PROGRess IN ALl-HazARDS Mitigation, OfF. OF INSPECTOR General, DeP'T OF HOMELAND SECURITY 23 (Oct. 2009), https://www.oig.dhs.gov /assets/Mgmt/OIG_10-03_Oct09.pdf.

29242 U.S.C. $\S 5133(\bar{h})(2)(2018)$ (explaining that small, impoverished communities with mitigation plans are eligible for pre-disaster mitigation grants). 
to relate to increasingly variable storm impacts predicted for the Oregon Coast.

DOGAMI is making progress in identifying the scope of hazards and is sharing that information with local governments and private landowners. Oregon now has a Natural Hazards Mitigation Plan (a NHMP). The current version was approved by FEMA on September 24, 2015, as an Enhanced Plan effective through September 23, 2020.

In the future, it is likely that FIRMs will need to locate not just the flood fringe line or the high wave (VE line) for flood insurance purposes, but also the line for protecting endangered species. ${ }^{293}$ Two cases illustrate that FEMA may have to modify its lines where endangered or threatened species are involved. In Florida, the Eleventh Circuit Court of Appeals prevented the issuance of flood insurance for new development in the suitable habitats of the Florida Key Deer. ${ }^{294}$ Similarly, in a case arising in Washington State, FEMA was required to consult with the National Marine Fisheries Service when recognizing flood protection in the Puget Sound salmon habitat. ${ }^{295}$ The court's decision resulted in a determination that FEMA's National Flood Insurance Program, which issues Flood Insurance Rate Maps, incorrectly recognized flood protection from levees and walls that would allow construction in mapped areas. ${ }^{296}$ The reasoning was that this recognition would result in harm to estuaries, tidal areas and flood area, all of which are parts of the salmon's habitat. ${ }^{297}$ Because of the endangered species listings of these two species, and because of the possible indirect effects of the Flood Insurance Program on development in possible habitats, the court granted injunctions requiring consultation and species protection. ${ }^{298}$

293 See FEMA, FEMA's NFIP ESA CONSUlTATION IN OREGON (Nov. 2016), http://www.dfw.state.or.us/fish/CRP/docs/lower-columbia/meetings/2016/Oregon-NFIP _FEMA_Graves.pdf.

294 Fla. Key Deer v. Paulison, 522 F.3d 1133, 1136 (11th Cir. 2008) ("The district court found that FEMA and the FWS failed to comply with section 7 of the Endangered Species Act, with regard to FEMA's administration of the National Flood Insurance Program in the Florida Keys. FEMA and the FWS maintain that section 7(a)(2) of the Endangered Species Act does not apply to FEMA's provision of flood insurance and that FEMA has, in any event, fully complied with section 7.").

295 Nat' 1 Wildlife Fed'n v. FEMA, 345 F. Supp. 2d 1151, 1174 (W.D. Wash. 2004).

296 Id.

297 Id. at 1177.

298 Id. 
During 2017, three major documents addressed climate change in Oregon: the Oregon Global Warming Commission's 2017 Biennial Report to the Legislature, ${ }^{299}$ the Oregon Climate Change Research Institute's (OCCRI) Third Oregon Climate Assessment Report of January, 2017, ${ }^{300}$ and the Fourth National Climate Assessment, which summarizes the work of several private sector and U.S. government agency physical scientists. ${ }^{301}$ Under Oregon's Statewide Planning Goal 7, each of these reports should be reviewed by the DLCD and forwarded to local governments for action within thirty-six months. ${ }^{302}$ The impediment to these actions lies in Oregon's notice statute, which requires DLCD to provide notice of any rule or required local zoning change to local governments, who must then notify all affected landowners; DLCD is responsible for providing notice costs. ${ }^{303}$ Thus, budgetary restrictions thwart Goal 7 and proper notice of climate change impacts.

One concept not set forth in the Goals or implementing rules is recognition of rolling easements; that is, uses and lines that divide them should change in anticipation of predictable climate change impacts. This concept should be a part of changes to Goal 7 as well as Goals 15, 16, 17, and 18. Climate change may result in more damage from storm surge and high waves. It may cause the ordinary low water line of the Willamette River and other waters to change as river flows are much less during hotter and drier summers. Flash floods from more rapid spring runoffs may change the channels and islands of the river and erode recreational trails and structures along the river. Setback lines should be able to "roll" with ocean and river changes. For Oregon's coastal shorelands located in estuaries, rolling easements need to be established that will move as the ocean rises, storms surge, and tidal or tsunami bores occur. ${ }^{304}$ These could be identified as areas of concern on comprehensive plan and hazard

299 Biennial Report to the Legislature, supra note 14.

300 M.M. Dalton Et Al., OR. Climate Change Research Inst., The ThiRd OREgOn ClimAte ASSESSMENT REPORT (Jan. 2017) [hereinafter THE THIRD OREGON CLIMATE ASSESSMENT REPORT], http://www.occri.net/media/1042/ocar3_final_125_web .pdf.

301 U.S. Global Change Research Program, Fourth National Climate Change Assessment, http://www.globalchange.gov/nca4 (last visited Apr. 3, 2018).

302 OR. ADMIN. R. 660-015-0000(7) (2018).

303 OR. REV. STAT. ANN. § 197.047 (West 2018).

304 See generally JAMES G. TITUS, EPA, ROLLING EASEMENTS (2011), http://www2 .epa.gov/sites/production/files/documents/rollingeasementsprimer.pdf (providing a summary of tools that could be used to respond to sea level rise). 
maps. They need to reflect the current science as to impacts from subsidence, sea level rise, and storm surge. Oregon, with its vaunted planning system, should be able to predict these events and make anticipatory decisions.

Sea level rise will occur, and summer runoff will deplete riverine wetlands. Shallow, estuarine areas and wetlands are essential for salmonid rearing. As shallow area needs become more acute, diked lands will need to be reclaimed. DLCD is working on the location of diking districts as now shown on its Coastal Atlas. ${ }^{305}$ To maintain the viability of Oregon's estuaries, these diking district lands may need to be reclaimed for public use. As storm surge and sea level rise occur, reliction lines need to move-rather than remain fixed-either through common law or through the recognition of "rolling easements." 306 DLCD's 2009 publication, Climate Ready Communities, encourages planning for Oregon coastal communities, ${ }^{307}$ but it doesn't provide mandates. Changing the goals would be one way to provide mandates to address climate change impacts.

Further, DLCD doesn't take on the really hard problems of (1) private versus public property after a major event; (2) what infrastructure and housing will and won't be replaced-e.g., sewers, water, roads, and electricity; (3) whether there will be rolling easements to match sea level rise and storm surge; (4) how Oregon's beloved public wet sand and dry sand beach widths will continue to be accessible, even as sea levels rise; and (5) in what ways does adaptation to climate change differ from adaptation to a very big (i.e., level 9) subduction earthquake and tsunami. Unless Oregon answers these questions, its vaunted planning process is little better than that for New Orleans in its response to Hurricane Katrina, or those in New York and New Jersey in anticipation of responses to the likes of Hurricane Sandy.

305 See Estuary Data Viewer, OR. COASTAL ATLAS, http://www.coastalatlas.net /index.php/tools/planners/63-estuary-data-viewer (last visited Apr. 6, 2018).

306 See generally TITUS, supra note 304.

307 See generally CLIMATE READY COMMUNITIES, supra note 32 (providing a strategy for coastal communities and agencies for the State of Oregon to plan for global warming impacts on the Oregon coast). 


\section{Adaptation Potential 3-Modify Goal 16}

Goal 16, Estuarine Resources, ${ }^{308}$ should be modified to provide regulatory adaptation guidance to local and state governmental entities for: maintaining shallow water areas otherwise resulting in loss of estuarine and wetland areas, establishment of rolling easements in currently diked off areas to maintain habitat lost as a result of sea level rise, and capacity to accommodate faster runoff due to earlier snow melt and weather patterns. Oregon's twenty-two estuaries will be affected by global sea level rise. Sea level rise for the Oregon coast at Newport, for example, may reach forty-seven inches above mean sea level by $2100 .{ }^{309}$ The numerous potential impacts to estuaries, in addition to sea level rise, include the following: acidification; temperature rise, loss of wetland habitat, upwelling, fresh water runoff, and sedimentation; ${ }^{310}$ the breaching, or possible breaching, of ocean spits (as almost happened at Tillamook bay in $1952,{ }^{311}$ at Siletz bay in $1973,,^{312}$ and at Netarts Bay in $2007^{313}$ ); changes in the intrusion of the salt-water wedge where the ocean meets fresh water; temperature increases at $0.5^{\circ} \mathrm{F}$ per decade; ${ }^{314}$ faster runoff; winter storms; and other local atmospheric dynamics and local vertical land movements from a Cascadia Subduction Earthquake of magnitude 8 or higher and that has a $16 \%$ to $22 \%$ chance of happening in the next fifty years. ${ }^{315}$

Oregon's estuaries are important to juvenile salmon for several reasons: (1) tidal creeks, marshes, eelgrass beds, and channels furnish

\footnotetext{
308 OR. ADMIN. R. 660-015-0010(1) (2018).

309 THE THIRD OREgOn ClimATE AsSESSMENT REPORT, supra note 300, at 32 (2017); ClimAte READY COMMUNITIES, supra note 32, at 12.

310 THE THIRD OREgON ClimATE ASSESSMENT REPORT, supra note 301, at 88; Hatchery, OSU Scientists Link Ocean Acidification to Larval Oyster Failure, OR. STATE UNIV. (Apr. 11, 2012), https://www.ucsusa.org/sites/default/files/attach/2015/03/ucs-con fronting-climate-change-oregon-2015.pdf (explaining that acidification from raised levels of $\mathrm{CO}_{2}$ in Netarts Bay, Oregon prevented survival of the larva from commercially raised oysters in 2012).

311 Paul D. Komar, The Pacific Northwest Coast: Living with the Shores of OREGON AND WASHINGTON 84 (1998).

312 Id. at 93.

313 Vicki S. McConnell, State Geologist, OR. DeP'T of Geology and Mineral INDUS., OREGON BEACH SHORELINE MAPPING AND ANALYSIS PROGRAM: QUANTIFYING SHORT-TO-LONG-Term BeACH AND SHORELINE Changes IN THE GOLD BEACH, NeSIKA Beach, and Netarts litToral Cells, Curry and TillamooK COUNTIES, OREgON 1, 9, 33 (2013).

314 Climate ReAdy Communities, supra note 32, at 12.

315 THE THIRD OREGON CLIMATE ASSESSMENT REPORT, supra note 300, at 35.
} 
young salmon with productive feeding areas where they forage and grow before heading out to sea; (2) shallow estuarine habitats offer refuge from predators, especially from marine mammals, birds, and fish that hunt for juvenile salmon in deep channels and near-shore areas; and (3) brackish estuarine waters provide an acclimation area for salmon smolts while they adapt to the marine environment. ${ }^{316}$

Additionally, Oregon's coastal planning must fit into a Coastal Zone Management Plan acceptable to the National Oceanic and Atmospheric Administration (NOAA) under the Federal Coastal Zone Management Act. ${ }^{317}$ Significant work is being done under the auspices of DOGAMI concerning changes in the location of the mouths of estuaries in connection with updating FEMA's FIRMs. ${ }^{318}$

While government programs, such as Goal 16, exist for estuary health, the Wetlands Conservancy, a private entity, is actively protecting wetlands. Recognizing that the coast has lost some $70 \%$ of its wetlands since 1981, the Wetlands Conservancy has preserved close to 900 acres of wetlands along the Oregon Coast. ${ }^{319}$

Goal 16 divides estuaries into natural, conservation, shallow-draft development, and deep-draft development estuaries. The Goal provides the following:

[I]n all estuaries, areas shall be designated to assure the protection of significant fish and wildlife habitats, of continued biological productivity within the estuary, and of scientific, research, and educational needs. These shall be managed to preserve the natural resources in recognition of dynamic, natural, geological, and evolutionary processes. Such areas shall include, at a minimum, all major tracts of salt marsh, tideflats, and seagrass and algae beds. ${ }^{320}$

316 See, e.g., Paul Hoobyar, Salmon and Estuaries: Vital linkages learned at Salmon River, OR. SEA GRANT 4 (2007), http://seagrant.oregonstate.edu/sites/seagrant.oregonstate .edu/files/sgpubs/onlinepubs/g07003.pdf.

31716 U.S.C.A. $\S 1451$ (West 2018); See also NAT'L OCEANIC AND ATMOSPHERIC Admin., CoAstal Zone Management Act Section 309 Program Guidance 2016 to 2020 ENHANCEMENT CYCLE (2014) (explaining specific guidance for Section 309 climate change enhancement program).

318 For an example, see the movement of the mouth of Sand Lake to the north since the 1920s, as shown in IAN P. MADIN, OR. DEP'T OF GEOlOGY \& MinERAL Indus., COASTAL FloOd HAZARD StUdy, TILlaMOOK COUNTY, OREGON 27 fig.2-19 (2015).

319 See Our Preserves, THE WETLANDS CONSERVANCY, http://wetlandsconservancy .org/conservation/preserves/ (last visited Apr. 9, 2018).

320 OR. ADMIN. R. 660-015-0010(1) (2018). 
The Statewide Planning Goals require that diversity among Oregon's estuaries be maintained. ${ }^{321}$ Under Goal 16, natural estuaries are for habitat protection, but the uses existing as of October 7, 1977, may remain. Conservation estuaries are to be managed for long term uses of renewable resources that do not require major alterations of estuarine resources; such estuaries can be in urban areas. Shallowdraft estuary main channels are limited to twenty-two feet in depth. Both shallow-draft and deep-draft estuaries may have natural, conservation, and development management units. ${ }^{322}$

\section{Adaptation Potential 4-Modify Goal 17}

Goal 17, Coastal Shorelands, should be modified to add an implementation requirement addressing the impacts of a fifty-year projection of climate changes to all development within shoreland planning areas and assuring that all beachfront protection structures provide access to and along the beaches at a projected mean higher high tide level, meeting the fifty-year projection, and should assure that rolling easements are part of Oregon's planning process.

321 LUBA's comment on the legality of adopting a plan amendment that redesignates a portion of the estuary from conservation to development to facilitate construction of a proposed Liquefied Natural Gas terminal was:

As we understand the applicable Goal 16 language, those findings are adequate and supported by substantial evidence. There is no evidence that an LNG terminal is likely to reduce the diversity of existing maritime uses of the estuary. At best, petitioners' evidence suggests that (1) if federal agencies impose large, strict exclusion zones for LNG tankers, and (2) if too many LNG tankers dock at the terminal during a given period of time, there may be significant delays that could negatively impact commercial fishermen, cruise ships and recreational boaters attempting to use the navigation channels or cross the bar at the same time as transiting tankers. As the city explained, petitioners' concerns are speculative and depend on worst-case scenarios and variables that cannot be known at the present time. Even if those variables were known at the time of the city's decision, we fail to see that the cited delays and similar inconveniences are the kind or degree of impacts that could possibly result in a failure to "maintain the diversity of important and unique economic features within the estuary."

To the extent the city deferred consideration of petitioners' evidence and arguments concerning adverse impacts on maritime traffic, that deferral seems appropriate. As explained, evidence of such impacts is only contingently relevant to the only applicable Goal 16 requirement cited to us. Consideration of such evidence is highly relevant, however, under the code standards cited in Condition 2, which require evaluation of whether a specific LNG terminal will interfere with the public trust rights, including commercial and recreational boating.

People for Responsible Prosperity v. City of Warrenton, 52 Or. LUBA 181, 195-96 (2006).

322 OR. ADMIN. R. 660-015-0010(1) (2018). 
Statewide Planning Goal $17,{ }^{323}$ dealing with Oregon's coastal shorelands, provides a deep root for the sense of place shared by Oregonians, past and present. The shorelands also provide the scenic core of Oregon's tourism business. ${ }^{324}$ Sea level rise and storm surge along those coastal shorelands are causing FEMA, with the help for DOGAMI, to revise Oregon FIRMs. New predictions for the ocean's hazardous wave heights are resulting in setting "high velocity zones" 325 for flood areas shown on these maps as high as fifty-six feet above sea level in places. ${ }^{326}$ To coastal property owners, this is significant because loans secured by mortgages on property in flood zones require flood insurance. ${ }^{327}$ In addition, major storms have occurred, such as the 1997-1998 El Niño events that caused dramatic erosion at Cape Lookout State Park and at The Capes development, ${ }^{328}$ both bordering Netarts Bay.

Oregon's coastal shorelands goal should be read together with its tsunami law. First, Oregon's subduction earthquake and tsunami law results in the creation of Tsunami Inundation Maps (TIMSs), which designate hazardous areas resulting in special geological/ geotech evaluations. ${ }^{329}$ Examples of essential facilities include: hospitals, fire and police stations, water tanks, major structures such as tall buildings (over six stories), hazardous facilities containing significant toxic or explosive substances, and special occupancy structures like schools, jails and auditoriums. ${ }^{330}$ The Tsunami Inundation Zone is set by

323 Id. 660-015-0010(2).

324 See, e.g., Best Oregon Beaches, BEST BEACHES, http://www.best-beaches.com/us /oregon/best-oregon-beaches (last visited Apr. 9, 2018).

325 See Coastal High Hazard Area, FEMA, http://www .fema.gov/coastal-high-hazardarea (last updated Dec. 11, 2017, 5:10 PM).

326 Peter Ruggiero, Climate Controls on Northeast Pacific Wave Heights and Total Water Levels, in ADAPTING TO CLIMATE CHANGE ON THE OREGON COAST: A CITIZEN'S GUIDE 30, 34 (2015).

327 See Fed. Emergency Mgmt. Agency, Flood Insurance: How It Works (2015), https://www.fema.gov/media-library-data/1427811288492-36fb55e74d14c318db299658 0527d131/Flood_Insurance_How_It_Works.pdf.

328 See Geologic Hazards on the Oregon Coast: The Capes-a case study of a coastal landslide, OR. DEP'T OF GEOLOGY \& MiNERAL INDUS., http://www.oregongeology.org /sub/earthquakes/Coastal/TheCapes.htm (last visited Apr. 9, 2018); Vic Affolter, Lessons from the Capes, in ADAPTING TO CLIMATE CHANGE ON THE OREGON COAST 61 (2012).

329 See OR. DEP'T OF GEOLOGY \& Mineral InduS., The 2011 Japan earthquake and tsunami: Lessons for the Oregon Coast, CASCADIA (Winter 2012), at 10, 11. An example of site review requiring a geology report is found in Crowley v. City of Bandon, 43 Or. LUBA 79, 96 n.1 (2002).

330 OR. REV. STAT. ANN. § 455.447 (West 2018). 
DOGAMI, ${ }^{331}$ and covers many communities such as Rockaway Beach $^{332}$ and Cannon Beach. ${ }^{333}$

The Coastal Shorelands Goal requires planning for a mix of conservation, appropriate development, and restoration. In addition, the goal's purpose is, "[t]o reduce the hazard to human life and property, and the adverse effects upon water quality and fish and wildlife habitat, resulting from use and enjoyment of Oregon's coastal shorelands." 334 Under the current goal requirements, as local governments plan, they must include policies and uses for:

- areas subject to ocean flooding; lands within 100 feet of the ocean shore and lands within 50 feet of an estuary or coastal lake;

- areas where geologic instability will impact a coastal water body;

- land resources needed to stabilize the shoreline, maintain water quality and temperature needed to maintain fish habitat and spawning areas;

- significant shoreland and wildlife habitats;

- areas needed for water-dependent and water-related uses; and

- areas of exceptional aesthetic or scenic quality, and coastal headlands. ${ }^{335}$

The general priorities for uses in coastal shorelands include: promoting uses, which maintain the integrity of estuaries and coastal waters, and providing for water-dependent uses. ${ }^{336}$

Goal 17's implementation requirements include: requiring forest uses that protect and maintain special shoreland values; retention of riparian vegetation, a preference for non-structural solutions over rip-

331 Id. $\S 455.446(1)(\mathrm{b})$ (West 2018).

332 Ruggiero, supra note 326; see also TILlamook CTY., TILlamook County, MUlTi-JURISDiCTION NATURAL HAZARDS Mitigation PLAN 222 (2017).

333 See Tsunami, CITY OF CANNON BEACH, http://www.ci.cannon-beach.or.us/emer gencymgmt/page/tsunami (last visited Apr. 6, 2018); see also Geologic Hazards on the Oregon Coast: A Look at New Tsunami Inundation and Evacuation Maps at Cannon Beach, OR. DEP'T OF GEOLOGY AND MinERAL INDUS., http://www .oregongeology.org /tsuclearinghouse/projects-cannonbeach.htm (last visited Apr. 6, 2018) (documenting the City of Cannon Beach's tsunami risk plan, and maps detailing tsunami inundation and evacuation).

334 OR. ADMIN. R. 660-015-0010(2) (2018).

335 Id.

336 Id. § 660-037-0050 (2018) (indicates that the pressure of local governments to use waterfront in the estuaries for non-water dependent uses resulted in a 1999 rule limiting water-dependent use in specific areas, while permissible areas include those currently being used for a water-dependent activity and those that have been used in the past and contain have a dock that is still useful). 
rap, groins, jetties and similar structures; and retention of public access to and along coastal shorelands. ${ }^{337}$ The implementation requirements of the Goal provide, in part, that:

1. Major marshes, significant wildlife habitat, coastal headlands, and exceptional aesthetic resources ... shall be protected. ... ;

5. Land-use management practices and non-structural solutions to problems of erosion and flooding shall be preferred to structural solutions. Where shown to be necessary, water and erosion control structures, such as jetties, bulkheads, seawalls, and similar protective structures; and fill, whether located in the waterways or on shorelands above the ordinary high water mark, shall be designed to minimize adverse impacts on water currents, erosion, ${ }^{338}$ and accretion patterns; [and]

6. Existing public ownerships, rights of way, and similar public easements in coastal shorelands which provide access to or along coastal waters shall be retained ${ }^{339}$ or replaced if sold, exchanged or transferred. Rights of way may be vacated to permit redevelopment of shoreland areas provided public access across the affected site is retained. ${ }^{340}$

The Oregon coast faces a stark scenario for tsunamis. The predictions are that the level of the Oregon Coast near its beaches, estuaries, and ocean-side urban areas just above sea level, could be subject to liquefaction, ${ }^{341}$ and could subside or drop between 1.6 and 4.9 feet as a result of the subduction. ${ }^{342}$ Then, within approximately

337 Id. § 660-015-0010(2) (2018).

338 A LUBA referee summarized an implementation requirement of Goal 17 as: "Excavation or grading within a setback area in coastal shorelands is inconsistent with Goal 17 , implementation requirement 5 , and implementing local provisions to the extent excavation or grading increases the erosion rate of existing ocean bank material protecting new structures from erosion.” Terra v. City of Newport, 36 Or. LUBA 582, 604 (1999).

339 LUBA has opined that Implementation Requirement 6 of Goal 17, which requires that local governments shall retain or replace existing rights of way that provide access to or along coastal waters, unambiguously provides mandatory approval requirements.

Or. Shores Conservation Coal. v. Lincoln Cty., 164 Or. App. 426, 437 n.1 (1999).

340 OR. ADMIN. R. 660-015-0010(2) (2018).

341 Or. SEISMIC SAFETy Policy AdVISORY COMMITTEe, OREgON RESILIENCE Plan 7 (2013), http://www.oregon.gov/oem/Documents/01_ORP_Cascadia.pdf.

342 Curt D. PETERSon, et Al., DeP'T. OF GeOlogy AND Mineral Indus., ESTIMATES OF COASTAL SUBSIDENCE FROM GREAT EARTHQUAKES IN THE CASCADIA SUBDUCTION ZONE, VANCOUVER ISLAND, B.C., WASHINGTON, OREGON, AND NORTHERNMOST CALIFORNIA 1 (1997) (reporting that abrupt subsidence occurred in the 1700 CE Cascadia Subduction Earthquake); see Robert Yeats, Earthquakes and Tsunamis in the Cascadia Subduction Zone, Or. Encyclopedia (last updated Mar. 17, 2018), https://oregonencyclopedia.org/articles/cascadian_subduction_zone/\#.WgpcSv_2a70. 
fifteen minutes, the subduction-caused ocean wave will arrive on the coast, with a height that could reach 100 feet. ${ }^{343}$

One highly important climate change adaptation response that needs to be addressed, and soon, is Oregon's "lines in the sand" response. ${ }^{344}$ Oregon's Beach Bill specifies the area of concern as the "ocean shore," an area along the beach that runs seaward from the "vegetation line," meaning that the vegetation line determines the westerly boundary of Coastal Shorelands. While the vegetation line is surveyed with the metes and bounds as specified the Oregon Revised Statutes, if the line of established upland vegetation is further inland, then that will be the line of the "ocean shore." ${ }^{345}$ Oregon's State Parks and Recreation Department is tasked with periodic examination of the line for the preservation of public and private rights and interests in the area, and making recommendations to the legislature on any changes in the statutory line. ${ }^{346}$ The Oregon Parks and Recreation Department Commission is charged with making recommendations to the legislature on changes in the statutory vegetation line, and in doing so, it must consider at least: "(a) [t] he density and location of vegetation at and near to the segment for which a change is requested; [and] (b) [t] he extent of the shift of the actual vegetation line."347

A careful reading of the definition of "ocean shore" leads to an inference that there are two processes: (1) the statutory amendment process, and (2) an independent determination based on movement of the line of upland vegetation. However, the existence of the surveyed statutory vegetation line serves as a direct impediment to adapting to the sea level rise and heightened storm surge of climate change. The law needs to require an update of laws every ten years based on climate change factors, which should be presented to the legislature for action regarding the vegetation line; the line needs to move when storm surge has changed the nature of the vegetation.

343 See the tsunami evacuation brochure prepared for Cannon Beach by DOGAMI, $\mathrm{http}$ //www.oregongeology.org/pubs/tsubrochures/CannonBeachEvacBrochure-5-21-13on screen.pdf (last visited Apr. 7, 2018).

344 See Courtney B. Johnson \& Steven R. Schell, Adapting to Climate Change on the Oregon Coast: Lines in the Sand and Rolling Easements, 28 J. ENVTL. L. \& LiTIG. 447, 458-81 (2013) (providing an overview of Oregon's "lines in the sand"); Steven Bender, Castles in the Sand: Balancing Public Custom and Private Ownership Interests on Oregon's Beaches, 77 OR. L. REV. 913 (1998) (exploring the relationship between the rights of the public and interests of the dry sand owner).

345 OR. REV. STAT. ANN. § 390.605(2) (West 2017).

346 Id. $\S 390.755(1)$.

347 OR. ADMIN. R. 736-023-0030(3) (2018). 
Because coastal processes constantly change rolling easements need to be recognized and implemented in Oregon. ${ }^{348}$

\section{Adaptation Potential 5-Amend Goal 18}

Goal 18, Beaches and Dunes, should be changed to recognize and preserve the public trust accompanying reliction caused by impacts of rising sea levels, storm surge, and larger waves on the commonly held public easement for use of the dry sands portions of the State's beaches. Climate change will impact the values set out in Beaches and Dunes, Oregon's Statewide Planning Goal 18. For example, in the 2014 National Climate Assessment, scientists predicted a significant sea level rise by 2100 in Newport, Oregon, ranging from three to fifty-two inches, with a median of about twenty-four inches. ${ }^{349}$ Oregon coastal scientists have indicated that waves of sixty-six feet or higher can occur along the Oregon Coast. ${ }^{350}$

Physically, beaches and dunes have several different parts. Starting in the upland, there may be stable sand dunes, many with upland forests and urban development on them. Closer to the traditional beach, there may be conditionally stable dunes, areas where there have been changes, but perhaps not recently. At some point the upland vegetation gives over to beach vegetation. Over time, areas seaward from the stable dunes are frequently low lands where water in the form of ponds or lakes exists - deflation plains. Seaward from deflation plains are the active dunes, areas of sand shaped by the winds and waters of the ocean. The "ocean shore," a defined term in Oregon, ${ }^{351}$ extends from extreme low tide landward to the statutorily defined vegetation line, ${ }^{352}$ at about sixteen feet above the defined sea

348 See Rolling Easements: A Primer for Coastal Managers, RisingSEA.NET, http://papers.risingsea.net/rolling-easements-2-2-1.html (last visited Apr. 7, 2018).

349 The Third National Climate Assessment, supra note 301, 492 fig. 21.3; see also CAL. COASTAl COMM'N, SEA Level Rise Policy Guidance: InTERPRETIVE Guidelines for AdDRESSING SEA LEVEl Rise in COASTAl Programs AND COASTAL DEVELOPMENT PERMITS 213 (2015), https://documents.coastal.ca.gov/assets/slr/guidance /August2015/0_Full_Adopted_Sea_Level_Rise_Policy_Guidance.pdf (predicting sea level rise at Newport Oregon by 2030 to be $3^{\prime \prime}\left(\overline{+} /-2^{\prime \prime}\right)$; by 2050 to be $7^{\prime \prime}(+/-4)$; and by 2100 to be $25^{\prime \prime}$ ( $(+/-11)$.

350 Heather M. Baron et al., Incorporating Climate Change and Morphological Uncertainty into Coastal Change Hazard Assessments, 75 NAT. HAZARDS 2081 (2015), https://link.springer.com/article/10.1007/s11069-014-1417-8.

351 OR. REV. STAT. ANN. § 390.605(2) (West 2018).

352 Id. $\S 390.770$. 
level. Finally, the area below the line of mean higher high tide is called the wet sands portion of the beach. ${ }^{353}$

Oregon's seventeen littoral cells, plus the Columbia River littoral cell, have received much attention since adoption of Goal 18, and, as part of a national assessment. The U.S. Geological Survey published a major summary, based on many research papers, of the historical changes of these cells along the Oregon shoreline. One of those cells, Neskowin, is a harbinger of possible effects of future climate change along the Oregon Coast, where waves breaking close to shore scoured the beach and undercut the protective riprap for long-established coastal residences. ${ }^{354}$ Neskowin has an adaptation plan. ${ }^{355}$

Legal changes arising out of climate change must address at least five different sets of laws that shape how Oregonians manage their beaches and dunes. First, in 1913 the Oregon legislature adopted a law, proposed by then Governor Oswald West, reserving the wet sands portion of the Beach for transportation. ${ }^{356}$ In 1947, the Oregon Legislature amended the law expressly to cover recreation. ${ }^{357}$ Second, in 1967, the Legislature adopted Oregon's Beach Bill, confirming and codifying a common usage of the dry sands portion of the beach up to the vegetation line. ${ }^{358}$ Oregon's Supreme Court sustained the law, finding common usage from time beyond memory. ${ }^{359}$ A third element is the $\mathrm{V}$ or VE line for storm surges as established by FEMA in the FIRMs. ${ }^{360}$ Fourth, there is a definition for jurisdiction of Oregon's

353 Paul Komar, Ocean Processes and Hazards along the Oregon Coast, 54 OR. GEOLOGY, 7, fig.7, 17 fig.29 (1992), http://www.wou.edu/ vanstem/ORcoast.pdf.

354 Peter Ruggeiro et Al., U.S. Geological SerV., National AsSessment of SHORELINE CHANGE: HistoricAl SHORELINE CHANGE ALONG THE PACIFIC NORTHWEST COAST 42 (2013), http://pubs.usgs.gov/of/2012/1007/pdf/ofr2012-1007.pdf; see also Rebecca Woolington, After Rainfall Wreaks Havoc on Oregon Coast, Tillamook County Declares Emergency, OREGONLIVE (Dec. 9, 2015, 5:40 PM), http://www.oregonlive.com /pacific-northwest-news/index.ssf/2015/12/after_rainfall_wreaks_havoc_on.html.

355 Tillamook Cty. Dep'T of CMTy. Dev., The Neskowin CoAstal Erosion ADAPTION PLAN (2013), http://www.co.tillamook.or.us/gov/ComDev/documents/plan ning/Website\%20Forms/Revised\%20Neskowin\%20Adaptation\%20Plan\%2025Jun14.pdf.

3561913 Or. Laws Ch. 47.

3571947 Or. Laws Ch. 493.

358 See OR. REV. STAT. ANN. §§ 390.610, 390.615 (West 2018) (covering legislative policy and state ownership of the Pacific shore).

359 State ex rel. Thornton v. Hay, 462 P.2d 671, 673, 254 Or. 584, 587-88 (Or.1969).

360 FEMA Zone Definitions, FLOOD ADVOCATE, http://www.floodadvocate.com/fema -zone-definitions/ (last visited Apr. 8, 2018). 
Division of State Lands (DSL) in terms of Waters of the State. ${ }^{361}$ Finally, Oregon's DEQ claims jurisdiction of "Public Waters" or "Waters of the State." ${ }^{362}$ It is possible for DLCD to reconcile the lines and language for these lines and areas, but a full review and modification to each set of laws will assure that the public interest is protected.

\section{Adaptation Potential 6-Amend Goal 19}

Oregon's Oceans, under Goal 19, for the 3 miles off-shore, must reflect changes to the crab fishery and oyster production caused by acidification, oxygen depletion, and the change in fish habitat caused by $\mathrm{CO}_{2} \mathrm{e}$ absorption into ocean waters and temperature rises. Statewide Planning Goal 19, Ocean Resources, ${ }^{363}$ requires:

Prior to taking an action that is likely to affect ocean resources or uses of Oregon's territorial sea, state and federal agencies shall assess the reasonably foreseeable adverse effects of the action. . . . State and federal agencies shall carry out actions that are reasonably likely to affect ocean resources and uses of the Oregon territorial sea in such a manner as to ... protect:

1. renewable marine resources-i.e., living marine organisms - from adverse effects of development of nonrenewable resources, uses of the ocean floor, or other actions;

2 . the biological diversity of marine life and the functional integrity of the marine ecosystem;

3. important marine habitat, including estuarine habitat, which are areas and associated biologic communities[; and ] . . .

4. areas important to fisheries.

By rule, DLCD incorporates the Ocean Management Goals and Policies $^{364}$ as part of its Oregon Coastal Management Program. ${ }^{365}$

361 OR. CONST. art. XI-D, $\S 1$ (explaining that Oregon owns the land under navigable waters). See, e.g., Winston Bros. Co. v. State Tax Comm'n, 156 Or. 505, 62 P.2d 7 (1936) (holding that for non-navigable waters, the riparian owner has title to the thread of the stream).

362 OR. ADMIN. R. 340-045-0010(21) (2018) (defining "Public Waters" or "Waters of the State").

363 Id. 660-015-0010(4) (2018).

364 See Or. Dep'T of LAND Conservation \& DeV., Oregon Territorial Sea Plan, PART ONE: OCEAN MANAGEMENT FRAMEWORK, OREGON.GOV (2001) [hereinafter OCEAN MANAGEMENT FRAMEWORK], http://www.oregon.gov/LCD/OCMP/docs/ocean lotsp_1-g.pdf. 
Policy 3 of that program lists as one of the management measures, a "Cumulative Effects Assessment" that provides a mandate "to act with regard for the accumulated consequences or effects of activities in the environment that may occur at a distance, over time, or in combination with other actions." 366

The United States has not ratified the 1982 Law of the Sea Treaty but notwithstanding this, the United States asserts a 200-mile exclusive economic zone as provided in the Treaty as customary. ${ }^{367}$ Oregon asserts a right to control the territorial sea, which is three nautical miles from "mean lower low water" along the Oregon coast, as recognized by the federal and state governments. ${ }^{368}$ Statewide Planning Goal 19 is intended to conserve ocean resources for the benefit of future generations, ${ }^{369}$ and it is directed toward this threemile area. Under its Territorial Sea Plan, Oregon, even though it neither owns nor controls it, also claims a right of "ocean stewardship" over an area beyond the three-mile limit to the toe of the continental shelf. 370

Within its three-mile territorial sea area, Oregon confronts several climate change related issues. ${ }^{371}$ Oregon's Crab fishery is threatened by acidification and hypoxia, ${ }^{372}$ which dissolves exoskeletons. Already, acidification has had an impact on oyster spawning, as shown by the Whiskey Creek oyster larvae loss incident. ${ }^{373}$ Oregon is

365 OR. ADMIN. R. 660-036-0003 (2018). While the regulation references the 1999 Ocean Management Goals and Policies, Oregon's Territorial Sea Plan of 2013 includes a more recent amendment from May 4, 2001.

366 OCEAN MANAGEMENT FRAMEWORK, supra note 364, at 2.

367 See NAT'L OCEANIC \& ATMOSPHERIC ADMIN., What is the law of the sea?, https://oceanservice.noaa.gov/facts/lawofsea.html (last visited Apr. 8, 2018).

368 OR. DEP'T OF LAND CONSERVATION \& DEV., 1994 TERritorial SEA Plan, app. D, http://www.oregon.gov/LCD/OCMP/docs/ocean/otsp_app-d.pdf (last visited Apr. 8, 2018).

369 OR. ADMIN. R. 660-015-0010(4) (2018).

370 OCEAN MANAGEMENT FRAMEWORK, supra note 364, at app. G.

371 NAT'L OCEANIC \& ATMOSPHERIC ADMIN., supra note 367.

372 See Letter from Patty Snow et al. to Catherine Gockel, Office of Water \& Watersheds (Aug. 3, 2017), https://www.epa.gov/sites/production/files/2017-08/docu ments/r10-npdes-offshore-seafood-gp-wa-or-wag520000-comments-odeq-odfw-ocmp-08 -03-2017.pdf (regarding a condition for issuance of an NPDES permit that would specify the ocean depth over which the permitted disposal of processing wastes must occur from vessels fishing for whiting when they dispose of processing where the applicant has specified 100 meters, but the Oregon agencies want 200 meters, arguing impacts on acidification and hypoxia in territorial sea waters).

373 A scientific investigation by Oregon State University researchers determined that the larvae loss was definitively linked to ocean acidification. The $\mathrm{pH}$ of ocean 
confronting El Nińos, similar to those in 1982-83 that started to erode Cape Lookout State park, located at the base of the Netarts spit. ${ }^{374}$ The 1997-98 El Niño undercut the sandy area for a residential coastal development, The Capes, built near the mouth of Netarts Bay. ${ }^{375}$ This El Niño had four waves that exceeded the then 100-year height projection, ${ }^{376}$ according to OSU wave expert Peter Ruggiero. ${ }^{377}$

In addition, the release of methane-frozen in hydrates from the oceans - can be a tipping point, ${ }^{378}$ and there is developing evidence of destabilization from deep-water warming of methane that has been bound in hydrates at ocean depths of about 500 meters (i.e., the edge of the continental shelf). ${ }^{379}$

water historically hovered around 8.16 (7 is a neutral $\mathrm{pH})$, but over the last two centuries, the oceans have absorbed a third to half of the carbon dioxide emitted through the burning of fossil fuels. This has resulted in increasingly acidic water, and the average $\mathrm{pH}$ of the world's oceans is now 8.05. This may not seem like a big change, but since the $\mathrm{pH}$ scale is logarithmic, the $\sim 0.1$ drop indicates a $30 \%$ increase in ocean acidity. With the current carbon emissions pathway we're on, ocean acidification is expected to jump by $150 \%$ compared to historical averages by the end of the century ... Though the $\mathrm{pH}$ of the world's oceans has shifted over millennia, the current rate of ocean acidification is at least 10 times faster than anything the Earth has experienced over the last 50 million years.

Kirsten Howard \& Allie Goldstein, Cracking the Case of the Vanishing Oyster Larvae, GREAT AM. ADAPTATION ROAD TRIP (Sept. 4, 2013), https://adaptationstories.com/2013 /09/04/cracking-the-case-of-the-vanishing-oyster-larvae/.

374 Paul Komar, El Nino and Coastal Erosion in the Pacific Northwest, 60 OR. GEOLOGY 57, 62 (1998), https://www.wou.edu/las/physci/taylor/gs331/komar.pdf.

375 Geologic Hazards on the Oregon Coast: The Capes-a case study of a coastal landslide, supra note 329.

376 See Paul D. Komar \& Jonathan C. Allan, Or. St. Univ., Analyses of EXtreme WaVEs AND WATER LEVEls ON THE PACIFIC NoRThWEST COAST 6-7, 17 (2000), http://www.oregon.gov/LCD/OCMP/docs/publications/extreme_wavestide_rpt .pdf.

377 See Peter Ruggiero, Or. Shores Conservation Coal., Adapting to Climate Change on the Oregon CoAst: A Citizen's Guide 30 (2015), https://oregon shores.org/sites/default/files/ClimateChangeOnTheOregonCoast-March2015.pdf.

378 U.S. Glob. Change Research Program, National Climate Assessment 2014 at FAQs (Are there tipping points in the climate system?) (2014), http://nca2014 .globalchange.gov/report/appendices/faqs\#narrative-page-38761/ (last visited Apr. 8, 2018) (defining tipping points in terms of abrupt changes); CLIMATE SCIENCE SPECIAL REPORT, supra note 8, at 460, 470 (defining the terms "abrupt climate change" and “tipping point.").

379 WORLD OCEAN REV., supra note 175. 
Another significant problem affecting Oregon coastal waters is increasing dead zones related to climate change along Oregon's coast: $^{380}$

[S]cientists are discovering dead zones in areas where there is little or no nutrient runoff from farms, near the Oregon coast, for example. Researchers at Oregon State University attribute these near-shore hypoxic events to climate-driven changes in ocean circulation that intensify the upwelling of nutrients from deeper waters, which triggers dramatic plankton growth and subsequent die-off. ${ }^{381}$

The commercial and sports fisheries for bottom fish in Oregon's territorial sea have challenged the recognition that marine sanctuaries as not needed to allow big, old, fat females to spawn, and complete the requisite replenishment of bottom fish stocks. ${ }^{382}$ Warmer waters, particularly as they return to the tributary streams of Oregon and its estuaries, but also in the oceans, have threatened the offshore anadromous Coho, sockeye, and chinook salmon runs. ${ }^{383}$

Finally, the tides and waves produce energy that theoretically can be captured, but there are technical problems, including mooring lines for the wave energy machines that interfere with gray whale migrations. ${ }^{384}$

380 The relationship between climate change and dead zones is complex. When seawater gets warmer, it holds less dissolved oxygen. Layers of ocean water also become more stratified, and it gets harder for oxygen-rich surface layers to mix with deeper water. Warming at the poles affects the formation of deepwater currents that move water around the Pacific. Changing wind patterns on land affect how often upwelling occurs. Though the exact mechanism driving dead zone expansion is unclear, studies show that it's happening and will likely increase. One model predicts a 50 percent increase in low-oxygen water by the end of the century. As the zones spread, they reduce the number of habitats for many of the sea creatures we eat.

Josh Dzieza, Climate change could mean massive ocean dead zones, THE VERGE (Jan. 28, 2015, 3:41 PM), http://www.theverge.com/2015/1/28/7930047/climate-change-couldmean-massive-ocean-dead-zones.

381 Patrick Parenteau, Species and Ecosystem Impacts, in THE LAW OF ADAPTATION TO Climate Change 310 (Michael B. Gerrard \& Katrina Fischer Kuh eds., 2012).

382 See, e.g., James Holman, Fisherman Wary of Oregon's plans for Marine Reserves, (Mar. 4, 2008, 6:25 PM), OREGONLIVE, http://blog.oregonlive.com/pdxgreen/2008/03 /newport_gov_ted_kulongoski.html.

383 Lisa Crozier, Nw. Fisheries SCI. CTR., Impacts of Climate Change on SALMON OF THE PACIFIC NORTHWEST (2016), https://www.nwfsc.noaa.gov/assets/4 19042_02102017_105951_Crozier.2016-BIOP-Lit-Rev-Salmon-Climate-Effects-2015.pdf.

384 Robert Paasch et al., Wave Energy: a Pacific Perspective, PHILOSOPHICAL TRANSACTIONS OF THE ROYAL SOC'Y A 481, 494 (2011). 


\section{Adaptation Potential 7-Modify the Greenway Goal}

The Greenway Goal should be modified to assure that mapping of the 100-year flood areas matches the predicted spring runoff events. The Willamette River, the subject of Statewide Planning Goal 15, ${ }^{385}$ is the main water artery of Oregon. It drains the western slope of the Cascade Range, Oregon's backbone, as well as the eastern slope of Oregon's Coast range. Climate change will cause less snow and faster runoff in the headwaters of the River, but also more demand on the river because of increased summer heat. ${ }^{386}$ By about 2080 there will be no more snowpack on the Oregon Cascades. ${ }^{387}$ The risks to the built environment in the upper Willamette valley basin are high and numerous. Such risks include flooding of sixty percent of the taxable land within 2009 designated floodplains, increased turbidity, and more pollution from more frequent higher intensity rain events. ${ }^{388}$ FEMA's FIRMs need to be updated frequently so the Department of Land Conservation and Development can assure that hazard management zones are created for life and property protection.

\section{Sequestration Potential for Land Use Goals and Climate Change: Forests (Goal 4), Agriculture (Goal 3), and Open Space (Goal 5)}

Anthropogenic $\mathrm{CO}_{2} \mathrm{e}$ is disturbing the equilibrium that has evolved over millions of years between the land, the atmosphere, and the oceans as "sinks" for $\mathrm{CO}_{2} \mathrm{e}$. In addition to avoiding destabilization of the equilibrium by implementing policies to prevent an increase of anthropogenic $\mathrm{CO}_{2} \mathrm{e}$ (i.e., mitigation), it is necessary to take $\mathrm{CO}_{2}$ out of the atmosphere. This effort is referred to as sequestration. The Intergovernmental Panel on Climate Change (IPCC) has looked at 116 models for limiting temperature rise to no more than two degrees centigrade target, and finds that 101 of them require taking $\mathrm{CO}_{2} \mathrm{e}$ out

385 OR. ADMIN R. 660-015-0005 (2018).

386 THE THIRD OREGON ClIMATE ASSESSMENT REPORT, supra note 300, at 90.

387 Id. at 17.

388 PREPARING For Climate CHANGe IN THE UPPER WillametTe River BASIN OF WESTERN OREGON: CO-BENEFICIAL PLANNING FOR COMMUNITIES AND ECOSYSTEMS 13-15 (2009); THE THIRD OREGON ClIMATE ASSESSMENT REPORT, supra note 301, at 91-92; Climate Adaptation and Erosion and Sedimentation, EPA (Mar. 17. 2018), https://www.epa.gov/arc-x/climate-adaptation-and-erosion-sedimentation (last visited Apr. $8,2018)$. 
of the atmosphere, that is, "negative emissions." 389 Further, by 2100 , at least according to one expert, it will be necessary to have removed 810 billion tonnes (810 gigatons or GT) of $\mathrm{CO}_{2}$ from the atmosphere. ${ }^{390}$ After being released into the atmosphere $\mathrm{CO}_{2}$ may remain for a long time, depending on the uptake of various "sinks." Picking a benchmark of emissions in the year 1990, U.S. production of $\mathrm{CO}_{2}$ was about $15 \%{ }^{392}$ of the $\mathrm{CO}_{2}$ in the world. Oregon's share of $\mathrm{CO}_{2}$ emissions, according to one source, is $0.7 \%$ of the United States' share, ${ }^{393}$ which means Oregon would be responsible for sequestration of about 850 total MMT of $\mathrm{CO}_{2}$ by year 2100. If Oregon starts sequestration by 2030 , then, spread over seventy years, Oregon's sequestration rate should be about twelve million tonnes of $\mathrm{CO}_{2} \mathrm{e}$ per year. Where could this sequestration come from and what Statewide Planning Goals and policies could be used to attain this objective? Three possible sources in Oregon are forests, farming and carbon capture-storage. ${ }^{394}$

\section{Sequestration Potential 1-Modify Goal 4}

Goal 4 and state statutes should be modified to establish a forest sequestration requirement for Oregon of $12 \mathrm{MMT}^{395}$ per year

\footnotetext{
389 Greenhouse gases must be scrubbed from the air, ECONOMIST (Nov. 16, 2017), https://www.economist.com/news/briefing/21731386-cutting-emissions; CLIMATE SCIENCE SPECIAL REPORT, supra note 8, at ch. 4.

390 Id.

3915 to 200 years according to the IPCC. InTERgOvernMENTAL PANEL ON Climate CHANGE, FifTH ASSESSMENT REPORT (2013).

392 According to World Bank figures, the U.S. production in 1990 was about 6 GT against a world amount of 38 GT. Total greenhouse gas emissions (kt of CO2 equivalent), THE WORLD BANK (2018), https://data.worldbank.org/indicator/EN.ATM.GHGT.KT.CE ?end $=2012 \&$ start $=1990$ \&year_low_desc $=$ true.

393 Assuming 2014 figures are comparable to 1990 figures. The easiest site to use is https://en.wikipedia.org/wiki/List_of_U.S._states_by_carbon_dioxide_emissions\#Table. EPA temporarily took down its relevant data page. See https://mashable.com/2017/10 /20/epa-climate-website-missing-climate-change-references/\#fwQ_HQuZXPqg.

Wikipedia and Tableau Public have remnants of that data. Oregon is shown as having 78.5 million metric tons of $\mathrm{CO}_{2}$, https://public.tableau.com/profile/amy.botelho\#!/vizhome /CO2EmissionsbyState 1/USCO2Emissions. EPA is currently reviewing the 2016 numbers for its annual report as required under the Paris Agreements. For national emissions see https://www.epa.gov/ghgemissions/inventory-us-greenhouse-gas-emissionsand-sinks (last visited Mar. 18, 2018).

394 See Elizabeth C. Brodeen, Sequestration, Science, And The Law: An Analysis Of The Sequestration Component Of The California And Northeastern States' Plans To Curb Global Warming, 37 ENVTL. L. 1217, 1225 (2007).

395 Million Metric Tons - one metric ton or tonne is about $2205 \mathrm{lbs}$.
} 
commencing not later than 2030 and providing an implementation strategy by 2020. In planning, it is first necessary to recognize that the Federal Government owns 53\% of Oregon's more than 60 million acres of land, with the BLM and Forest Service having about 15 million acres each. ${ }^{396}$ It follows that if Oregon forested lands and vegetation are to be used for sequestration, then cooperation is necessary between the federal and state governmental entities. Given this need, changes to Oregon's Statewide Planning Goal for Forestry and state statutes are worth addressing.

Oregon's forests contain three billion tons of carbon (9.7 million tons of $\left.\mathrm{CO}_{2}\right){ }^{397}$ In the past, $\mathrm{CO}_{2}$ emissions from forest fires have averaged between 1.5 to 4 million tons of $\mathrm{CO}_{2}$ emissions a year. ${ }^{398}$ Oregon does not have a forest carbon accounting methodology, but it is building one. ${ }^{399}$

LCDC's Statewide Planning Goal 4 provides in part:

Forest operations, practices and auxiliary uses shall be allowed on forest lands subject only to such regulation of uses as are found in ORS 527.722. Uses which may be allowed subject to standards set forth in this goal and administrative rule are: (1) uses related to and in support of forest operations; (2) uses to conserve soil, water and air quality, and to provide for fish and wildlife resources, agriculture and recreational opportunities appropriate in a forest environment; (3) locationally dependent uses; [and] (4) dwellings authorized by law.

... Comprehensive plans and zoning provide certainty to assure that forest lands will be available now and in the future for the growing and harvesting of trees. Local governments shall inventory, designate and zone forest lands. Local governments shall adopt zones, which contain provisions to address the uses allowed by the goal and administrative rule, and apply those zones to designated forest lands.

\footnotetext{
396 Carol Hardy Vincent et AL., Cong. Research Serv., Federal Land Ownership: Overview and Data 8, 10 (2017), https://fas.org/sgp/crs/misc/R42346.pdf.

397 Biennial Report to the Legislature, supra note 14, at 28; see also Sarah L. Shafer et al., The Potential Effects of Climate Change on Oregon's Vegetation, FOREST RESOURCES INSTITUTE, https://www.fs.fed.us/pnw/olympia /silv/publications/opt/660_ShaferEtal2010 .pdf.

398 Id.; BIENNIAL REPORT TO THE LEGISLATURE 2017, supra note 14, at 28.

399 Id. at 28-39.
} 
Zoning applied to forest land shall contain provisions which limit, to the extent permitted by ORS 527.722 , uses which can have significant adverse effects on forest land, operations or practices. ${ }^{400}$

Under Oregon's land use system, both forest- and non-forestrelated uses are permitted in forest and farm-forest zones, subject to standards set forth in DLCD's administrative rules on forest land. ${ }^{401}$ However, there is an inherent tension between the Forest Practices Act (ORS Chapter 527) and Goal 4. Under the Forest Practices Act, there is exclusive regulation under the State Board of Forestry over all activities related to commercial forest practices on forest designated lands outside urban growth boundaries (such as shading of streams, stems per acre on riparian areas, replanting of cut-over land, and sizes of clear-cuts). ${ }^{402}$ Activities such as dwellings, parcel divisions, siting or other non-forest uses fall within the scope of Statewide Planning Goal 4. ${ }^{403}$ Given Goal 4's objective of conserving forests, the rules implementing the goals allow forest practices but make optional whether to allow forest uses for conservation of the air, water, and soil. ${ }^{404}$

Under Oregon law, the Oregon Board of Forestry may, but is not required to, develop a carbon offset program for Oregon's forests. ${ }^{405}$ If it does, then the rule implementing the program must: "[a]ccount for continuing carbon dioxide emission debits, and credits for carbon storage or sequestration, based on the end product use of harvested biomass. $"{ }^{406}$ Notwithstanding any rules developed by the Department of Forestry, the law allows others to negotiate forestry carbon credit offsets independent of the rules and requirements of the State Board of Forestry. ${ }^{407}$ While Oregon has not set up a carbon offsets program

400 Or. DeP'T OF LAND CONSERVATION \& DeV., Oregon's Statewide Planning Goals \& Guidelines Goal 4: Forest Lands, http://www.oregon.gov/LCD/docs/goals/goal4.pdf (last visited Mar. 1, 2018).

401 OR. ADMIN. R. 660-015-0000(4) (2018); Forest Land Protection Program, OR. DEP'T OF LAND CONSERVATION \& DEV., http://www.oregon.gov/LCD/pages/forlandprot .aspx (last visited Oct. 9, 2017).

402 OR. REV. STAT. ANN. § 527.722 (West 2017).

403 See 1000 Friends of Oregon v. Land Conservation \& Dev. Com., 305 Ore. 384, 752 P.2d 271 (1988).

404 See OR. AdMIN. R. 660-006-0025(2)-(3) (2018).

405 OR. REV. STAT. ANN. § 526.786(1) (West 2017).

$406 I d . \S 526.786(3)(\mathrm{f})$ (West 2017).

407 Id. $§ 526.789$ (West 2017). 
as a broad measure, California has, and it provides specifications for use of carbon offsets in Oregon forests. ${ }^{408}$

Oregon is a major softwood producer in the United States and its wood is used in structures that are sustainable and climate friendly. One determinant of sustainability is certification for structures under the Leadership in Energy and Environmental Design (LEED) program as developed by the U.S. Green Building Council. ${ }^{409}$ After much debate the Council accepted for LEED purposes the use of pacific coast wood certified as meeting the standards of the Forest Stewardship Council (FSC). ${ }^{410}$ The FSC standard includes leave areas (10 to $30 \%$ of a forest management area) and clear-cuts averaging forty acres to meet maximum limits for even aged stands. ${ }^{411}$ It would seem that the leave areas may be eligible for carbon offsets as anticipated by the California Air Resources Board and the Oregon authorizing legislation for an accounting system. ${ }^{412}$

While the Oregon Department of Forestry has not yet adopted an accounting system for carbon offsets, significant headway was reported in the Oregon Global Warming Commission's 2017 report to the Oregon legislature. ${ }^{413}$ Using a United States Forest Service data base for carbon pools in Oregon Forests, ${ }^{414}$ a task force of the Global Warming Commission believes it is now possible to measure or model carbon stores of above ground living matter and below ground dead ground carbon as well as carbon in the forest soils. This then can

408 See Compliance Offset Protocol U.S. Forest Offset Projects, CAL. AIR RES. BD., http://www.arb.ca.gov/cc/capandtrade/protocols/usforest/usforestprojects_2014.htm (last updated Dec. 2, 2015).

409 LEED, U.S. GREEN BLDG. COUNCIL, https://new.usgbc.org/leed (last visited Dec. 5, 2017).

410 USGBC Members Approve LEED V4, FOREST STEWARDSHIP COUNCIL (July 12, 2013), https://us.fsc.org/en-us/market/green-building/leed-v4.

411 Forest Management Certification, FOREST STEWARDSHIP COUNCIL, https://us.fsc .org/en-us/certification/forest-management-certification (last visited Mar. 18, 2018) (referencing FSC US Forest Management Standard (v1.0)).

412 See OR. Legislative Policy \& Research OfFice, Comparison of Cap-and-Trade Programs: California, Ontario, Quebec and Oregon SB 1070, https://www.oregonlegisla ture.gov/helm/workgroup_materials/program $\% 20$ comparison $\% 20$ chart $\% 2010 \% 2017 \% 201$ 7.pdf (last visited Mar. 1, 2018) (anticipating connection to the California Cap and Trade program for carbon offsets if Oregon in the future, SB 1070); but see Peter Weisberg, California-First Offset Policy Endangers Cap and Trade Legality, THE CLIMATE TRUST (July 10, 2017), https://climatetrust.org/california-first-offset-policy-endangers-cap-and -trade-legality-scor cher/.

413 See Biennial Report to the Legislature, supra note 14, at 28-30.

414 Id. at 42 , tbl.6. 
be used to determine the quantities and flows of carbon into and out of Oregon's forests. ${ }^{415}$ The Commission states: "[b]oth increased GHG sequestration and increased GHG release need to be understood to inform public policy on forest and grassland management for carbon outcomes." 416 As indicated at the beginning of this part, the use of Oregon's forests to sequester a significant portion of the 12 MMT, or whatever Oregon's share of sequestration needs should be, may well be within the realm of possibility.

\section{Sequestration Potential 2-Modify Goal 3}

Goal 3 should be modified to provide incentives for more climate change friendly farming practices that will permanently sequester more carbon.

Agriculture, Statewide Planning Goal 3, provides: "Agricultural lands shall be preserved and maintained for farm use, consistent with existing and future needs for agricultural products, forest and open space and with the state's agricultural land use policy. . . ."417

The policy recognizes open land used for agriculture as an efficient means of conserving natural resources, ${ }^{418}$ but there is no recognition of climate change and the potential for sequestration on agricultural lands. A 2007 study for the California Energy Commission on the potential for reforestation of Oregon cropland and range found that nineteen million acres of range land and five million acres of crop land could be available for reforestation at an offset price of $\$ 20$ per metric tonne of $\mathrm{CO}_{2}-{ }^{419}$ this could generate sequestration of more than four billion tonnes of $\mathrm{CO}_{2}$ over an eighty-year period. ${ }^{420}$ While the loss of this many acres of crop land and range land to reforestation may well be unacceptable to the Oregon agricultural community, the National Center for Appropriate Technology has provided a list of agricultural techniques and land uses for sequestration of $\mathrm{CO}_{2}$ including: conservation tillage and reduced field pass intensity;

415 Id. at 35.

$416 \mathrm{Id}$. at 36.

417 Or. DeP'T OF LAND Conservation \& DeV., Oregon's Statewide Planning Goals \& Guidelines Goal 3: Agricultural Lands, http://www.oregon.gov/LCD/docs/goals/goal3 .pdf (last visited Mar. 1, 2018).

418 OR. REV. STAT. ANN. § 215.243(1) (West 2017).

419 CAL. ENERgy COMM'N, CARbon SEQuestration Through Changes IN LAND USE IN OREGON: COSTS AND OPPORTUNITIES at 3, tbl. ES-1 (2007), http://www.energy.ca .gov/2007publications/CEC-500-2007-074/CEC-500-2007-074.PDF.

$420 \mathrm{Id}$. 
efficient nutrient management; crop diversity through rotations and cover crops; rotational grazing; and improved forage. ${ }^{421}$

Recent events, such as the approval by Oregon's Department of Environmental Quality of a Confined Animal Feeding Operation (CAFO) permit in Morrow County, lead to an inference that climate change impacts on Oregon farms, including sequestration requirements, apparently do not have a legal foundation. Oregon's Department of Agriculture, in its news of March 31, 2017, included a statement:

Air quality, an issue raised during public comment, is beyond the scope of the CAFO permit, which only regulates discharges to surface and groundwater. However, as part of the dairy's operational plan, Lost Valley Farm will implement Best Management Practices that mitigate emissions and has indicated a willingness to install a methane digester when it becomes economically feasible. ${ }^{422}$

A climate change focus on agricultural lands in Oregon requires enhancing the land to encourage re-sequestration-taking the $\mathrm{CO}_{2} \mathrm{e}$ out of the atmospheric sink and redepositing it into and on Oregon agricultural lands and woodlots. Farmers need incentives to do this. A cap-and-trade system, where money for credits would be available for re-sequestration, would encourage better farming practices. Dairy operations and CAFOs need to be analyzed for their methane contributions to climate change and should be required to provide mitigation. Again, a cap-and-trade system with an offset program, which would specify contributions and require mitigation, would further internalize costs into those aspects of the agricultural industry. Mitigation processes dealing with $\mathrm{CO}_{2} \mathrm{e}$ from agricultural practices and dairy farm emissions could be done through Goal 3 or through requirements managed by Oregon's DEQ. Finally, to the extent land use considerations play a role, sequestration targets could be set on a county-by-county basis with supportive infrastructure for crops that encourage no-till activity. Such actions will not only sequester carbon but also increase soil organic carbon and thereby enhance the

421 JefF Schahczenski \& Holly Hill, Agriculture, Climate Change And CARBON SEQUESTRATION 5-7 (2009), https://www.nrcs.usda.gov/Internet/FSE_DOCU MENTS/nrcs141p2_002437.pdf.

422 Press Release, Or. Dep't of Envtl. Quality, CAFO Permit Issued to Lost Valley Farm (Mar. 31 2017). See also Pete Danko, Regulators Approve Contested Permit for Eastern Oregon 'Mega-Dairy', PORTLAND BuS. J. (Apr. 3, 2017, 6:07 AM), https://www .bizjournals.com/portland/news/2017/04/03/regulators-approve-contested-permit-for-east ern.html. 
productivity of the land. In short, Statewide Planning Goal 3 needs to be updated to deal with sequestration issues.

\section{Sequestration Potential 3-Modify Goal 5}

Goal 5 should be modified to require identification of basalt formations reserved for sequestration use and areas threatened by fires. Goal 5: Natural Resources, Scenic And Historic Areas, And Open Spaces requires local governments to conduct the following inventories: riparian corridors, including water and riparian areas and fish habitat; wetlands; wildlife habitat; federal Wild and Scenic Rivers; State Scenic Waterways; groundwater resources; approved Oregon recreation trails; natural areas; wilderness areas; mineral and aggregate resources; energy sources; and cultural areas. ${ }^{423}$ In addition, local governments and state agencies are encouraged to maintain current inventories of the following resources: Historic Resources; Open Space; and Scenic Views and Sites. ${ }^{424}$ Following procedures, standards, and definitions contained in commission (i.e., LCDC) rules, "local governments shall determine significant sites for inventoried resources and develop programs to achieve the goal." 425

An additional method of sequestration is under development, namely, the idea of mixing $\mathrm{CO}_{2}$ with water and injecting the solution, a weak acid, into basalt, where over time it will harden and become a part of rocks. Oregon's Columbia River Basalts provide the resource for this purpose. ${ }^{426}$

Goal 5 could be changed to require mandatory inventories of open spaces for their sequestration potential. In addition, portions of the Columbia River basalts and other basalts could be designated as special areas suitable for sequestration. Possible sources of $\mathrm{CO}_{2} \mathrm{e}$ could be identified with the possibilities for their co-location, and their relationship to sequestration in the basalts could be imbedded in planning.

423 OR. DeP'T Of LAND Conservation \& DeV., Oregon's Statewide Planning Goals \& Guidelines Goal 5: Nautural Resources, Scenic \& Historic Areas, \& Open Spaces, $\mathrm{http} / / / w w w . o r e g o n . g o v / L C D /$ docs/goals/goal5.pdf.

424 Id.

$425 I d$.

426 See H. TOdD Schaef ET AL., Dissolution of Columbia River Basalt Under Mildly Acidic Conditions as a Function of Temperature: Experimental Results Relevant to the Geological Sequestration of Carbon Dioxide, 24 APPLIED GEOCHEMISTRY 980-87 (2009). 


\section{Land Use Process and Practice Issues-Goals and Climate Change: Citizen Involvement (Goal 1); Land Use Planning (Goal 2), and Related Processes}

As an overall matter, it is the 2017 observation of Oregon's Global Warming Commission that:

The State's climate policymaking machinery is not measuring up to the task of achieving GHG reduction goals and preparing the state for the effects of climate change. This failure is especially noteworthy for tasks not being informed by rigorous cost/benefit analysis, guided by agency assignments and benchmarks, and tracked for performance. ${ }^{427}$

Beyond that, many state agencies do not have measurable climate change compliance standards, and hence are unaccountable for compliance with $\mathrm{CO}_{2} \mathrm{e}$ goals.

Oregon's citizen involvement Statewide Planning Goal 1 anticipates involving citizens in all phases of the planning process. ${ }^{428}$ Two-way communication is required, including involvement not only in planning, but also in the major revisions of the plans and implementation measures. ${ }^{429}$ Understandable technical information is to be made available. ${ }^{430}$ Policy makers need to respond to citizens, and funding in needed to support the involvement process.

Statewide Planning Goal 2 for Land Use Planning specifies the general content and processes for adoption and amendment of local plans that are to be developed to meet the Goals adopted by the LCDC. ${ }^{431}$ Specifically, land use plans shall include:

[I]nventories and other factual information for each applicable statewide planning goal ... [and, in addition,] [a]ll land-use plans and implementation ordinances ... shall be reviewed and, as needed, revised on a periodic cycle to take into account changing public policies and circumstances, in accord with a schedule set forth in the plan. ${ }^{432}$

427 BIENNIAL REPORT TO THE LEGISLATURE 2017, supra note 14, at 44.

428 OR. DEP'T OF LAND CONSERVATION \& DEV., Oregon's Statewide Planning Goals $\&$ Guidelines Goal 1: Citizen Involvement, http://www.oregon.gov/LCD/docs/goals/goal 01.pdf (last visited Mar. 1, 2018).

$429 \mathrm{Id}$. at 2 .

$430 \mathrm{Id}$.

431 OR. DeP'T OF LAND CONSERVATION \& DeV., Oregon's Statewide Planning Goals \& Guidelines Goal 2: Land Use Planning, http://www.oregon.gov/LCD/docs/goals/goal2 .pdf (last visited Oct. 10, 2017).

432 Id. at 1. 
Plans must specify the ultimate policy choices ${ }^{433}$ and be "coordinated." 434 Recognizing that not all goals could be met in all circumstances, the goal also provides a three-alternative exceptions process-reasons, irrevocable commitment, and physically developed - and this process has developed a methodology and life of its own. ${ }^{435}$

The current problem is that neither Oregon's land use legal framework nor the implementing goals anticipated the need to mitigate or adapt to climate change or sequester carbon to avoid some climate change tipping point. While extensive citizen effort went into establishing the goals, ${ }^{436}$ adopting the initial local comprehensive plans to implement the goals, and designing the zoning to fit the goals and meet citizen concerns, this land use system is now encrusted with more than forty years of interpretations, policies, stakeholders, and institutions. ${ }^{437}$ Further, there doesn't seem to be either the citizen will or the political muscle to make changes to the current system. In addition, the nature of citizen involvement is changing. Unlike the 1973-74 time period when thousands of Oregonians participated in meetings and hearings regarding the content of the goals, in 2011 the Oregon Global Warming Commission had five public workshops across the state, had 125 people attend, and came up with eighty-eight responses to questionnaires, ${ }^{438}$ a rather poor showing among Oregon's 4 million people.

433 However, Goal 2 does not explain how a local government must make its ultimate policy choices or their form. See Home Builders Assoc. v. City of Eugene, 52 Or. LUBA 341, 366 (2006).

434 Plans are "coordinated" when the needs of all levels of government have been considered and accommodated as much as possible, and the local government has balanced the needs of all the affected governmental units and selected a particular course of action from among the competing proposed courses of action. Santiam Water Control Dist. v. City of Stayton, 62 Or. LUBA 149, 152 (2010) (citation omitted).

435 OR. REV. STAT. ANN. § 197.732(6) (West 2017); see OR. ADMIN. R. 660-004-0000 (2017) (interpreting the requirements of Goal 2).

436 Author Schell served on the initial Oregon Land Conservation and Development Commission. The Commission held many hearings across the state. More than 10,000 people were involved in the goal adoption process.

437 See generally Steven R. Schell, NIMBYs, Stakeholders and Legitimate Expectations - A View of 40 years of changes in Oregon's Land Use Regulation, 46 URB. LAW. 97 (2014).

438 State OF OR., OR. Glob. WARMing COMM'N, OGWC RoAdMaP to 2020 Phase 1 SUMMARY REPORT, at 1 (2011), https://static1.squarespace.com/static/59c554e0f09ca40 655ea6eb0/t/5a0a0ec553450af07cfb364d/1510608618426/2011

Roadmap+to+2020+Report.pdf. 


\section{Procedure Change 1-Adopt a Legislative Mandate to Update Goals for Climate Change}

Oregon's current land use decisionmaking infrastructure and its citizen involvement requirements do not generate citizen participation. A mandate from the Legislature, endorsed by the Governor, is needed to compel LCDC to take to the citizens of Oregon the climate change modeled consequences for Oregon, Oregon's target of $75 \%$ reduction by 2050 , and the local facts and questions related thereto. Currently, citizen involvement is monitored by a statutory Citizen Involvement Advisory Committee. ${ }^{439}$ In addition, there is also a statutory requirement for a Local Officials Advisory Committee. ${ }^{40}$ These mechanisms, while necessary, will never be sufficient to involve the citizens of Oregon in dealing with a set of issues as monumental as those raised by climate change. When the initial goals were adopted, the statutory requirement for ten hearings in different parts of the State was met. ${ }^{441}$ A similar process is needed for discussion and adoption of major revisions to the goals addressing climate change. It needs to use modern means of reaching Oregonians, educating them of the dire facts of climate change, and inviting their input.

\section{Procedure Change 2-Establish Land Use Path to 2050 Targets}

The Goals should establish the land use aspects of a path to 2050 with targets for various land uses. Recognizing the timing requirements already imbedded in the Goal process, the twenty-year supply of buildable land for housing ${ }^{442}$ needs to be made to fit within the $2050 \mathrm{CO}_{2} \mathrm{e}$ mitigation ${ }^{443}$ format. Likewise, for each industrial or other employment category, the plan —with its requirement to at least equal the projected land needs during a twenty-year planning period $^{444}$ — should have the 2050 target imbedded in its requirements. For transportation systems plans, the planning period of twenty years ${ }^{445}$ needs to provide a path forward to meet the 2050 target. $^{446}$ In

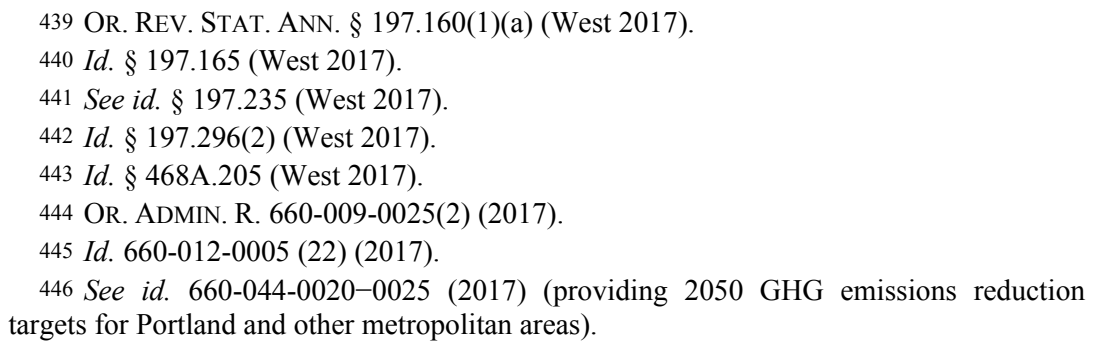


addition, there are provisions for urban and rural reserves that anticipate uses over fifty years; ${ }^{447}$ these also need to reflect climate change facts, projections, and land use changes.

\section{Procedure Change 3-Require Wholesale Review of Oregon Statutes to Deal with Climate Change}

Without wholesale review of Oregon statutes to deal with climate change, placing reconciling authority in Oregon's Global Warming Commission or elsewhere is not justified. Oregon's governing law is scattered over several different areas of land use practice including subdivision law, urban renewal, public housing entities, the Public Utilities Commission's regulations, development commissions, port authorities, environmental quality and services, and building codes. Recently, the Green Energy Institute has proposed strengthening the Oregon Global Warming Commission to regulatory status. ${ }^{448}$ Without the ability to overrule agency mandates or rewrite each agency's legislative mandate, such an effort merely creates another narrowly focused bureaucracy. ${ }^{449}$

\section{Procedure Change 4-Provide an Express Statement of Public Trust in Discretionary Permitting Procedures}

Discretionary permitting procedures should provide an express statement of the Public Trust using a standard requiring no substantial impact on climate change mitigation and adaptation objectives. The effectiveness of land use permitting systems worldwide is being questioned as climate change impacts become even more extreme. Climate change factors need to be considered in many of those systems. In addition, if the environmental claim that time is running out is substantiated, then many of the systems humans depend on for sustenance and even existence are threatened in the near future. Timing considerations must be part of the permit decision mix.

For example, mass extinctions occurred several times in Earth's history, often in conjunction with rapid climate change. New species evolved over millions of years, but those time scales are almost beyond human comprehension. If we drive many species to extinction we will leave a more desolate, monotonous planet for our children,

447 See OR. REV. STAT. ANN. § 195.145(4) (West 2017).

448 Melissa POWERS ET AL., COUNTDOWN TO 2050: SHARPENING OREGON'S Climate ACtion TOOLS 63-65 (2015).

449 See id. at 44. 
grandchildren, and more generations than we can imagine. We will also undermine ecosystem functions (e.g., pollination, which is critical for food production) and ecosystem resilience (when losing keystone species in food chains), as well as reduce functional diversity (critical for the ability of ecosystems to respond to shocks and stress) and genetic diversity that plays an important role for development of new medicines, materials, and sources of energy. ${ }^{450}$

Legislation should mandate that each discretionary regulatory permit process under the Statewide Planning Goals addresses the atmospheric public trust, ${ }^{451}$ made specific by Oregon's $75 \%$ reduction in $\mathrm{CO}_{2} \mathrm{e}$ from 1990 levels by 2050, and the need for attaining Oregon's fair share of sequestration goals necessary to maintain temperatures under $2^{\circ} \mathrm{C}$. Thus, the record in discretionary permit proceedings issued under the goals or their implementing plans and ordinances would include evidence and a finding, that granting the permit or approval of the plan or zone change ${ }^{452}$ will not contribute in any material way to cause a violation of the atmospheric Public Trust.

It seems time to make explicit, perhaps by initiative, an Oregon constitutional provision ${ }^{453}$ embodying the Public Trust Doctrine, to provide inter-generational standing and to enable courts to place limits on legislative, executive, and administrative actions that impair the long-term sustainability of commonly held resources such as the air, the water, and soil productivity. ${ }^{454}$

450 Hansen, supra note 10.

451 Mary Christina WoOd, NATURE's Trust: EnVironmental LaW FOR A NEW ECOLOGICAL AGE 330 (2014); see also the final decisions in litigation now pending, specifically, Juliana v. United States, 217 F. Supp.3d 1224 (D. Or. 2016), motion to certify appeal denied, No. 6:15-CV-01517-TC, 2017 WL 2483705 (D. Or. June 8, 2017) and Chernaik v. Brown Case No. A1519826 (Or. Ct. App., argued in 2016, decision still pending as of March 19, 2018); Michael C. Blumm \& Mary Christina Wood, "No Ordinary Lawsuit": Climate Change, Due Process, and the Public Trust Doctrine, 67 AM. U. L. REV. 1 (2017).

452 See OR. Rev. Stat. ANN. § 197.763 (West 2017); see id. § 215.416(9) (West 2017).

453 OR. CONST. art. I, $\S 10$ ("every man shall have a remedy by due course of law for injury done him in his person, property, or reputation"); OR. CONST. art. I, §33 ("The enumeration of rights, and privileges shall not be construed to impair or deny others retained by the people").

454 See generally WOOD, supra note 451 (providing a novel approach to empower citizens to use the Public Trust Doctrine to protect their inalienable ecological rights). 


\section{Procedure Change 5-Reinstate Periodic Review}

To remain current and relevant, Oregon's land use system depends on local plan acknowledgements ${ }^{455}$ and periodic review. ${ }^{456}$ While the acknowledgment process is alive and well, the periodic review process has largely broken down ${ }^{457}$ particularly on Oregon's Coast where the cities are less than 10,000 in population, and can be excluded from periodic review for up to 10 years. ${ }^{458}$ With climate change being more widely understood and appreciated, the periodic review process needs to be resuscitated to address the salient issues.

\section{Procedure Change 6-Modify Tort Liability for Elected Officials Who Ignore Climate Change}

Oregon's Tort Claims Act ${ }^{459}$ should not be a shield against liability for ignoring the consequences of climate change. The Act is full of exceptions or exclusions. For example, there is a limitation of liability for a single occurrence. ${ }^{460}$ Also, there is no liability for discretionary acts. ${ }^{461}$ However, there are exclusions for willful or wanton neglect and malfeasance. ${ }^{462}$ Like the Keizer flood case, ${ }^{463}$ liability needs to be recognized for state and local officials and employees who hold authority and have the knowledge, but have refused to act to address climate change issues.

The standards for public official and court actions with regard to climate change are being modified across the world. In France, local officials were held criminally liable and received jail sentences in early 2015 for concealing flood risk after a 2010 storm resulted in the deaths of 29 people. ${ }^{464}$ In New Orleans, a 2015 U.S. Court of Claims

455 OR. REV. STAT. ANN. § 197.015(1) (West 2017); id. § 197.251 (West 2017).

456 Id. $§ 197.629$.

457 Memorandum from Richard Whitman, Dir., \& Darren Nichols, Cmty. Servs. Div. Manager of Or. Dep't of Land Conservation \& Dev., to Land Conservation \& Dev. Comm'n (July 17, 2009), http://www.oregon.gov/LCD/docs/rulemaking/072909/item10 periodic_review_schedule.pdf.

458 See OR. REV. StAT. ANN. § 197.646 (West 2017); see also OR. ADMIN. R. 660-0250030(2)(b) (2017).

459 OR. REV. STAT. ANN. $\S \S 30.260-.300$ (West 2017).

$460 \mathrm{Id}$. $330.271(1)(\mathrm{c})$.

461 Id. $\S 30.265(6)(\mathrm{c})$ (West 2017).

462 Id. § 30.285(2) (West 2017).

463 See Hutcheson v. City of Keizer, 169 Or. Ct. App. 510, 8 P.3d 1010 (2000).

464 Jessica Wentz, Government Officials' Liability after Extreme Weather Events: Recent Developments in Domestic and International Case Law, ColuM. L. SCH. SABIN Ctr. for Climate Change L., Climate L. Blog (Feb. 18, 2015), http://blogs.law 
decision held that property owners in the St. Bernard's Parish had established that the Army Corps' actions, with respect to the Mississippi River Gulf Outlet, caused a subsequent storm surge exacerbated by a funnel effect during Hurricane Katrina (and later storms), resulting in flooding on plaintiffs' properties; that flooding effected a temporary taking under the U.S. Constitution's Fifth Amendment. ${ }^{465}$ In June of 2015, the Hague District Court in the Netherlands ruled that its government's efforts with regard to climate change were ineffective and ordered a reduction of $25 \%$ below 1990 levels of $\mathrm{CO}_{2} \mathrm{e}$ gasses by the year $2020 .{ }^{466}$ A Pakistan court, in 2015, ruled in favor of a farmer who had sued the national government for failure to implement a 2012 climate framework. ${ }^{467}$ In a June 24, 2015, decision, Washington's King County Superior Court ordered the Washington Department of Ecology (Ecology) to reconsider the petition of eight youth filed with Ecology last year asking for carbon dioxide reductions, and "to report back to the court by July 8, 2015, as to whether they will consider the undisputed current science necessary for climate recovery." 468 In addition, in an Illinois case, Farmers Insurance filed a complaint against several Illinois service districts and municipalities alleging failure of the storm water system, failure of the entities to respond to the known threats of greater intensity, volume and duration of storms arising out of climate change, and breach of the duty to exercise ordinary care in

\footnotetext{
.columbia.edu/climatechange/2015/02/18/government-officials-liability-after-extreme -weather-events-recent-developments-in-domestic-and-international-case-law/.

465 St. Bernard Parish Gov't v. U.S., 121 Fed. Cl. 687, 746 (2015).

466 Urgenda Foundation v. The St. of the Neth., C/09/456689 / HA ZA 13-1396 (2015).

467 Jessica Wentz, Lahore High Court Orders Pakistan to Act on Climate Change, Colum. L. Sch. Sabin Ctr. For Climate Change L., Climate L. Blog (Sept. 26, 2015), http://blogs.law.columbia.edu/climatechange/2015/09/26/lahore-high-court-orders -pakistan-to-act-on-climate-change/.

468 Order Remanding Department of Ecology's Denial of Petition for Rule Making, Foster v. Wash. Dep't of Ecology, No. 14-2-25295-1 (Wash. Sup. Ct. June 23, 2015); Washington Youth Win Unprecedented Decision in their Climate Change Lawsuit, W. ENVTL. L. CTR. (June 24, 2015), http://www.westernlaw.org/article/washington-state -youth-win-unprecedented-decision-their-climate-change-lawsuit-press-release. Later, settlement negotiations resulted in a rule-making proceeding which the trial court deemed sufficient on November 20, 2015. Foster v. Wash. Dep't of Ecology, 2015 WL 7721362 1, 4 (Wash. Sup. Ct. Nov. 19, 2015); Phuong Le, Judge Denies Kids' Climate Change Petition, The COLUMBian (Nov. 20, 2016, 10:04 PM), http://www.columbian.com /news/2015/nov/20/judge-denies-kids-climate-change-petition-2/.
} 
maintaining their property. ${ }^{469}$ While the Illinois case was dismissed before trial, it is not unreasonable to suggest that if Oregon communities and their elected officials don't respond to climate change threats after having foreseeable information about them, then they or the governments on which they serve could be subject to liability.

While public entities, public officials, and public employees acting with the scope of their authority are not liable for discretionary acts under Oregon law, ${ }^{470}$ an Oregon city and its engineering employees have been held liable for improper approval of subdivision plans where flooding resulted in damage to a homeowner because review of the subdivision plans by the engineers for possible flood damage was non-discretionary. ${ }^{471}$

Oregon law could be changed to require public officials to consider climate change mitigation, adaptation, and sequestration in all land use decisions and deem the consideration non-discretionary.

\section{E. Is Oregon Doing Enough, Soon Enough to Meet Its Share of the Climate Change?}

In the December 12, 2015, Framework Convention on Climate Change, the Conference of the Parties (COP 21):

Notes with concern that the estimated aggregate greenhouse gas emission levels in 2025 and 2030 resulting from the intended nationally determined contributions do not fall within least-cost $2{ }^{\circ} \mathrm{C}$ scenarios but rather lead to a projected level of 55 gigatonnes in 2030, and also notes that much greater emission reduction efforts will be required than those associated with the intended nationally determined contributions in order to hold the increase in the global average temperature to below $2^{\circ} \mathrm{C}$ above pre-industrial levels by reducing emissions to 40 gigatonnes or to $1.5^{\circ} \mathrm{C}$ above preindustrial levels by reducing to a level to be identified [in an upcoming special report from the IPCC in 2018). ${ }^{472}$

469 See Ill. Farmers Ins. Co. v. Metro. Water Reclamation Dist. of Greater Chi., No. 1:14-CV-03251, 3-5 (N.D. Ill. May 2, 2014) (dismissed shortly after the complaint was filed on June 3, 2014).

470 OR. REV. STAT. ANN. § 30.265(6)(c) (West 2017).

471 Hutcheson v. City of Keizer, 169 Or. App. 510, 8 P.3d 1010 (2000).

472 United Nations Framework Convention on Climate Change, Adoption of THE PARIS AGREEMENT DRAFT DECISION-/CP.21 3 (2015), https://unfccc.int/resource /docs/2015/cop21/eng/109.pdf. The 2013 annual rate was about 37 gmt. See generally Intergovernmental Panel on Climate Change, Climate Change 2014 Synthesis Report Summary for Policy Makers, Summary for Policy Makers at 3, tbl.(d). (2014), http://www .ipcc.ch/pdf/assessment-report/ar5/syr/SYR_AR5_FINAL_full_wcover.pdf. 
Is it enough? President Trump is withdrawing the United States from the COP 21 Climate Accords. The burden for U.S. compliance is therefore being shifted to the states and cities of the United States. Based on the 2017 report of Oregon's Global Warming Commission, Oregon is not doing enough to shoulder its share of climate change mitigation and sequestration. Nor is it doing it soon enough. Further, while the target is to keep Earth's temperature from rising more than $2{ }^{\circ} \mathrm{C}$, the pledges of all of the 196 countries involved in COP 21 would still result in temperature rises in the year 2100 averaging $3.5^{\circ} \mathrm{C}$ $\left(6.3^{\circ} \mathrm{F}\right) .^{473}$

However, the amount of $\mathrm{CO}_{2} \mathrm{e}$ is not the only question. How the atmosphere-land-oceans system responds is just as important. In geological time, mass extinctions have been attributed to disruptions in this system. ${ }^{474}$ The IPCC says that tipping points of large singular events have more of a chance of occurring when the temperature increases. ${ }^{475}$ Thus, the scientists are stating that under the present international scheme, with its $3.5^{\circ} \mathrm{C}$ result from the voluntary commitments of the 196 involved nations, there is still a high risk of reaching one or more irreversible tipping points.

Then there is a question of timing. Climate authority James Hansen says:

The important point is that the uncertainty is not about whether continued rapid $\mathrm{CO}_{2}$ emissions would cause large sea level rise, submerging global coastlines - it is about how soon the large changes would begin. The carbon from fossil fuel burning will remain in and affect the climate system for many millennia, ensuring that over time sea level rise of many meters will occurtens of meters if most of the fossil fuels are burned. That order of sea level rise would result in the loss of hundreds of historical coastal cities worldwide with incalculable economic consequences, create hundreds of millions of global warming refugees from highly-populated low-lying areas, and thus likely cause major international conflicts. ${ }^{476}$

473 Shanna Edberg, 27 Numbers for the Paris Agreement, Climate InTERACTIVE (Dec. 12, 2015), https://www.climateinteractive.org/blog/paris-agreement-by-the-numbers/.

474 See, e.g., Jeffery T. Kiehl \& Christine A. Shields, Climate Simulation of the latest Permian: Implications for Mass Extinction, 33 GEOLOGY 757, 757 (2005).

475 Intergovernmental Panel on Climate Change, Climate Change 2014 Impacts, Adaptation, and Vulnerability Summary for Policy Makers, at 12 (2014), http://www .ipcc.ch/pdf/assessment-report/ar5/wg2/ar5_wgII_spm_en.pdf.

476 Hansen, supra note 10, at 6. 
Hansen has indicated if the current course worldwide is followed, continued extraction of all fossil fuels, with $2 \%$ per year or growth continues for 20 years, followed by $3 \%$ per year of emission reduction from 2033 to 2150, would still leave massive amounts of residual $\mathrm{CO}_{2}$ in the various land- air-water sinks. Further, trying to extract the excess $\mathrm{CO}_{2}$ from the air in this case would be very expensive and perhaps implausible, and warming of the ocean and resulting climate impacts would be practically irreversible. ${ }^{477}$

\section{CONCLUSION}

So what may be done about climate change by a state that is comparatively large in size but comparatively small in population? The Paris Agreement is a coalition of the willing and has the resources of signatories and NGOs to research and propose actions to reduce climate change impacts. Oregon has a Global Warming Commission in place. It does have a target, i.e., $\mathrm{CO}_{2} \mathrm{e}$ reductions emission to be $75 \%$ of 1990 levels by $2050 .{ }^{478}$ It has taken steps to cause (in the case of Portland) and encourage (the other) Oregon metropolitan areas to reduce $\mathrm{CO}_{2}$ e to $20 \%$ below 2005 levels by $2035 .{ }^{479}$ It has in place a requirement for its private utilities to source $25 \%$ of electrical demand from renewables by $2025 .{ }^{480}$ It has allies in other states on the west coast that are like-minded (i.e., all but Alaska). ${ }^{481}$ Further, Oregon has committed to work closely with the Federal Government in implementing the Clean Power Plan, ${ }^{482}$ the CAFÉ standard of $54.5 \mathrm{MPG}^{483}$ and other Federal initiatives,

477 Id. at 18.

478 OR. REV. STAT. ANN. § 468A.205(1)(c) (West 2017).

479 See rules adopted by LCDC in 2011 to set this target. OR. ADMIN. R. 660-0440020(2) (2011).

480 See, e.g., OR. REV. STAT. ANN. § 469A.052(1) (West 2017).

481 The ability of northwestern states to work together on climate change gives the region a "leg up" on the economic and social disruptions of this phenomenon. Erin Brodwin, Why One Region of the US will Survive Climate Change Better than Any Other, According to Urban Planners, BUSINESS INSIDER (Sept. 30, 2017), http://www.business insider.com/region-states-us-best-survive-climate-change-2017-9.

482 Elizabeth Shogren, Why the West Will Continue to Green Even as Trump Rolls Back Climate Policy, HiGH COUNTRY NEwS (Mar. 28, 2017), http://www.hon.org/articles/-paris -climate-agreement-why-the-west-will-green-without-the-clean-power-plan.

483 Oregon and several other states have joined with California to adopt stricter auto emission standards than required by the federal government. Lauren E. Schmidt \& Geoffrey M. Williamson, Recent Developments in Natural Resource Law, 37 COLO. LAW. 63 (2008), https://www.bhfs.com/Templates/media/files/insights/08NovNatResourse .TCL.pdf. There is no indication that the state will relent on these standards at this time. 
assuming they, or some form thereof, survive the changes being made by the Trump administration. In addition, through FEMA, local hazard management plans are being modified to account for climate change adaptation needs. ${ }^{484}$ However, the Commission's 2017 report states: "[w]e appear to be on track to miss our 2020 goal by just under 11 million MTCO2e. In 2035, we project we will miss the Commission's adopted interim goal by just under 22 million MTCO2e." $" 485$

Oregon has about one percent of the population of the United States and is not a heavy polluter that will markedly affect climate change. But it can be an example for other American states as to what may be done. The state can and should revise the goals and policies of Oregon's unique and vaunted land use planning system, as suggested in this Article, so as to reflect the real and timely needs for additional mitigation, adaptation, and sequestration.

If the recommendations reviewed in this paper are followed, Oregon has an opportunity to build on its land use leadership in establishing and meeting policy choices that address the challenges of climate change and global warming to ensure the survival of the planet.

484 See FEMA National Advisory Committee, Climate Change at FEMA, U.S. DEP'T OF HOMELAND SEC. (2014), https://www.fema.gov/media-library-data/1397226777753-6a 93835a0eb470ecb7e5c6b9c3796b9a/NAC_Climate_Adaptation.031914_508c.pdf.

485 Biennial Report to the Legislature, supra note 14, at 8. 


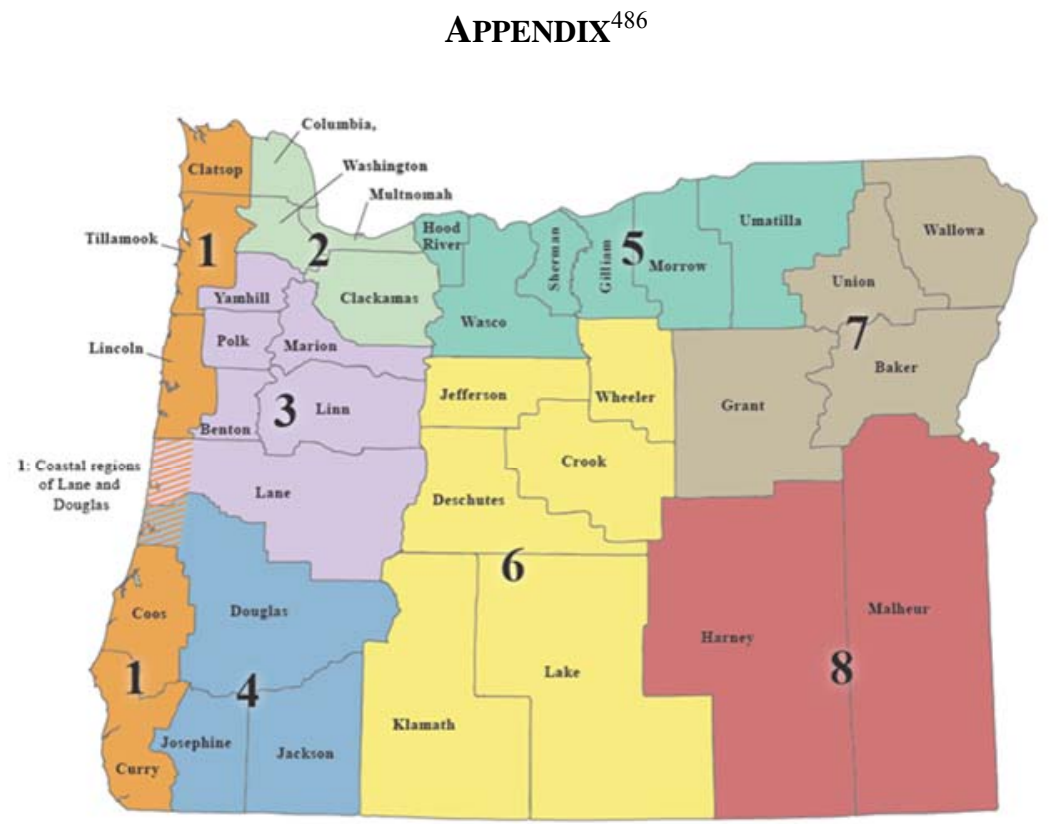

4862015 Oregon Natural Hazards Mitigation Plan, State Risk Assessment, STATE OF OR. 55 (2015), http://www.oregon.gov/LCD/HAZ/docs/2015ORNHMP/2015ORNHMP Approved/Approved_2015ORNHMP_5_RAState.pdf. 
